\title{
National Assessment Of Shoreline Change: Part 1 Historical Shoreline Changes And Associated Coastal Land Loss Along The U.S. Gulf Of Mexico
}

Robert A. Morton, Tara L. Miller, and Laura J. Moore

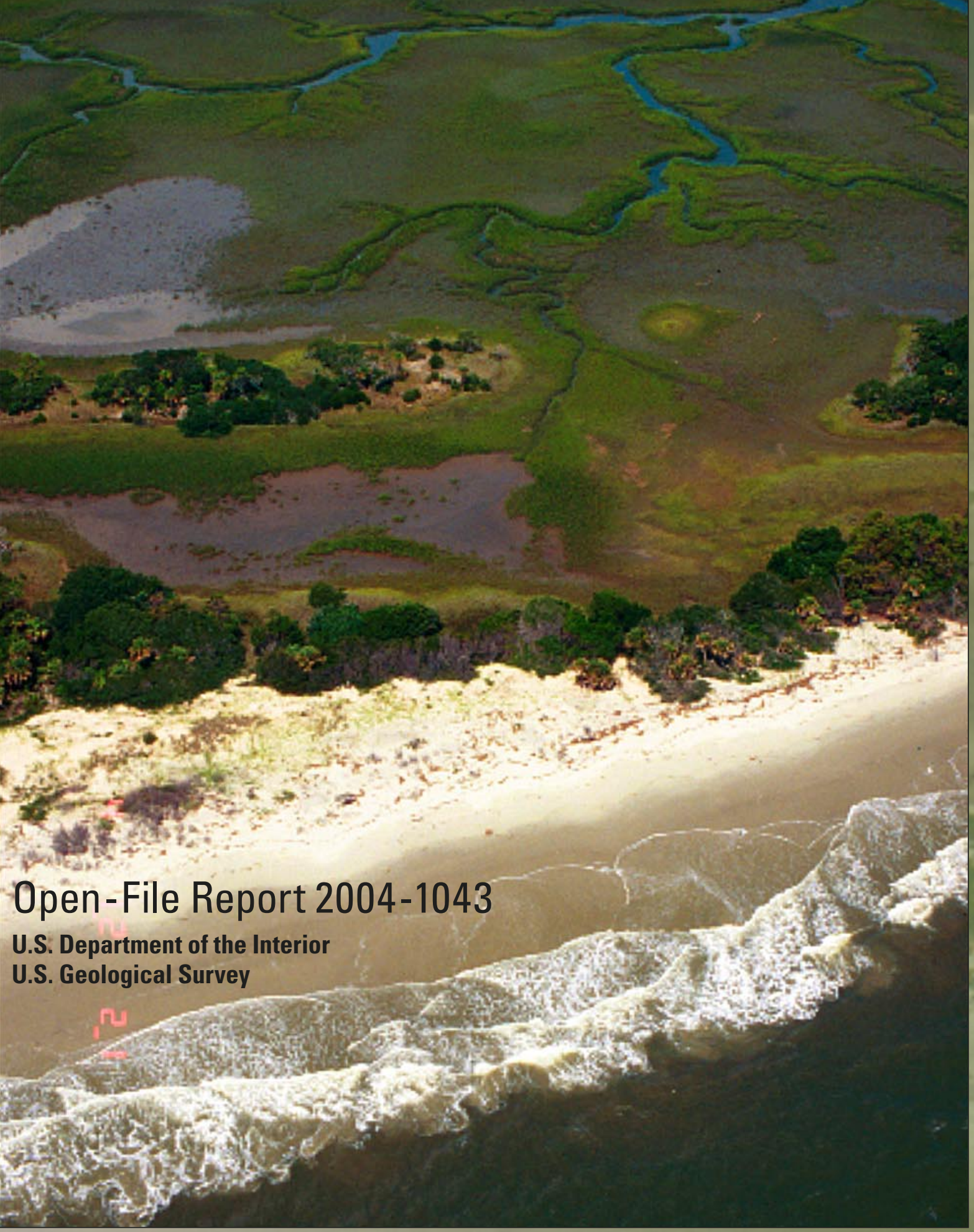




\section{National Assessment Of Shoreline Change: Part 1 Historical Shoreline Changes And Associated Coastal Land Loss Along The U.S. Gulf Of Mexico}

Robert A. Morton, Tara L. Miller, and Laura J. Moore

Open File Report 2004-1043

\section{U.S. Geological Survey}

\section{Center for Coastal and Watershed Studies}

St. Petersburg, FL 33701

This report is preliminary and has not been reviewed for conformity with U.S. Geological Survey editorial standards. Any use of trade names is for descriptive purposes only and does not imply endorsement by the U.S.Government.

Morton, Robert A., Miller, Tara L., and Moore, Laura J., 2004, National assessment of shoreline change: Part 1: Historical shoreline changes and associated coastal land loss along the U.S. Gulf of Mexico:

U.S. Geological Survey Open-file Report 2004-1043, 45p.

U.S. Department of the Interior

U.S. Geological Survey 


\section{Contents}

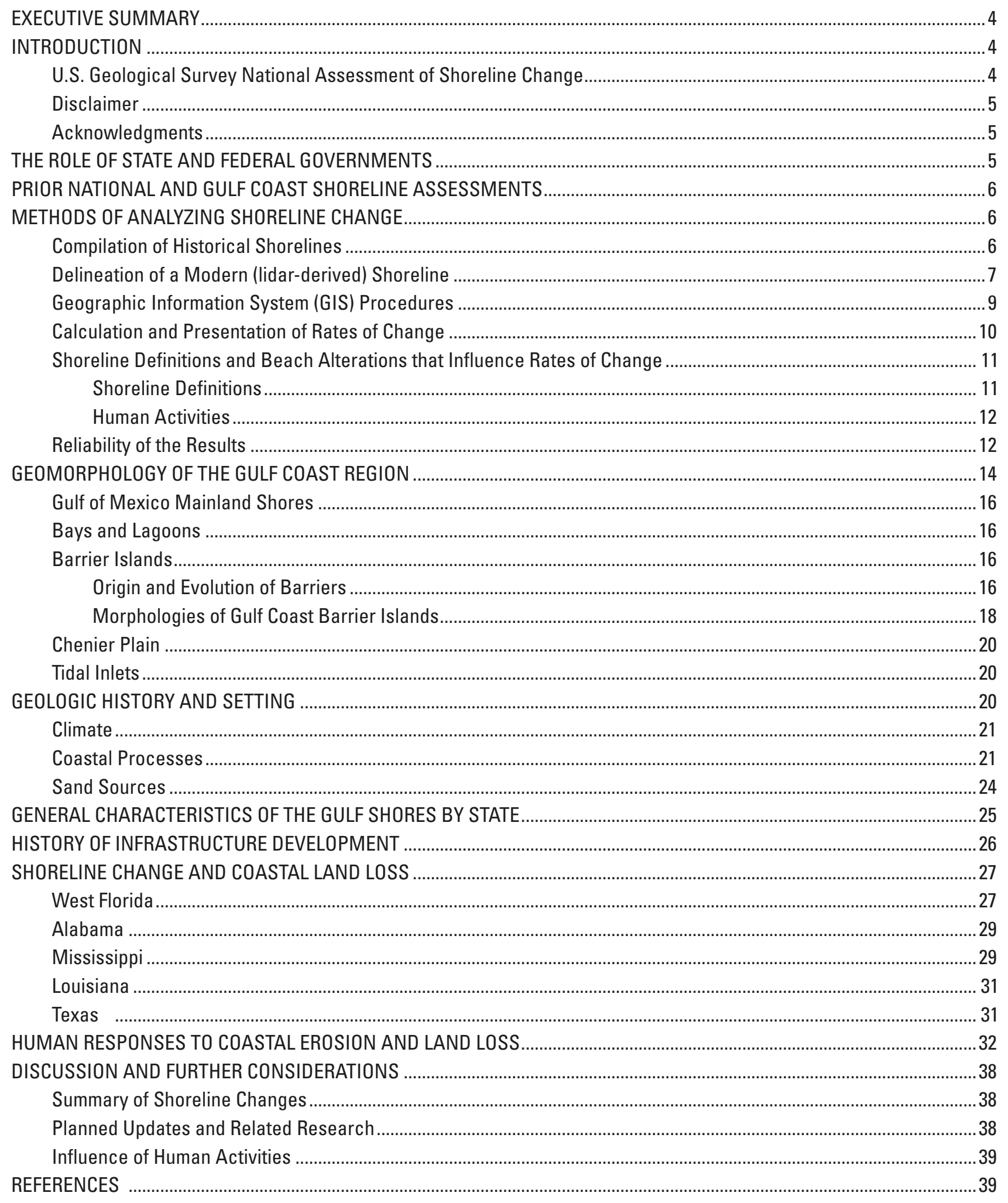




\section{Figures}

Figure 1. Example of a lidar profile from September 26, 1997 at Kitty Hawk, North Carolina for (a) the entire cross-shore region and (b) an expanded view of the foreshore region.

Figure 2. Examples of common conditions where transects are eliminated in the absence of four shoreline intersections.

Figure 3. Index map of the Gulf Coast region.

Figure 4. Common coastal landforms of the Gulf Coast region. ................................................................................16

Figure 5. Conceptual diagram showing possible origins of barrier islands. .....................................................................17

Figure 6. Sea level curve during the past 150,000 years that depicts the general magnitude and timing of sea level changes in the Gulf of Mexico. Modified from Moore (1982).

Figure 7. Geomorphological characteristics of high and low profile barrier islands. Modified from White and others (1978).

Figure 8. Long linear ridges and swales that characterize some Gulf Coast barrier islands, such as San Jose Island, Texas mark the former positions of the Gulf shoreline.

Figure 9. Fields of migrating sand dunes on North Padre Island, Texas may contribute to erosion by removing sand from the beach.

Figure 10. Long-term trends in average annual sea level at selected tide gauges in the Gulf of Mexico. Data are from the National Ocean Service.

Figure 11. A coastal subdivision of nearly 200 homes near Houston, Texas was submerged as a result of subsidence induced by ground-water production.

Figure 12. Tracks of some of the most deadly and destructive Atlantic and Gulf hurricanes in the 20th century.

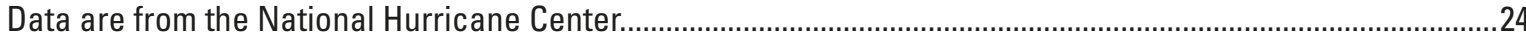

Figure 13. Property damage near Panama City, Florida caused by Hurricane Eloise in 1975. From Morton (1976).............25

Figure 14. Erosion of the Gulf shore eventually destroyed this beach house at Captiva Island, Florida..............................28

Figure 15. Even where wave energy is normally low, episodic erosion during storms is capable of destroying roads and eliminating the beach. This example of erosion along the low energy coast is from Lighthouse Point, Florida.

Figure 16. This narrow eroding beach in front of a seawall near Clearwater, Florida was used for recreation before beach nourishment.

Figure 17. Many nourished beaches along the west Florida coast, such as this one on Sand Key, have steep erosional escarpments early in the history of the project.

Figure 18. A beach nourishment project near Gulf Shores, Alabama. Accelerated erosion in front of the beach houses was attributed to construction of an artificial channel and jetties.

Figure 19. The seawall along U.S. 90 at Biloxi, Mississippi extends for nearly 27 miles.

Figure 20. Long-term Gulf shoreline erosion at Sargent Beach, Texas.

Figure 21. Multiple structures including a seawall, riprap, and failed groin field have been unable to stop erosion at Longboat Key, Florida. Later these structures were removed and the beach was nourished.

Figure 22. The breakwater at Redington Shores, Florida has protected the beach fill but has aggravated erosion of adjacent sand beaches.

Figure 23. Rock revetments and groins have been used to control beach erosion at Fort Gaines on the east end of Dauphin Island, Alabama.

Figure 24. Storm waves in the Gulf of Mexico destroyed the interlocking block revetment constructed to protect Louisiana State Highway 82 near Peveto Beach (Fig. 3). The revetment structure was replaced with 85 segmented breakwaters.

Figure 25. West end of the seawall at Galveston, Texas.

Figure 26. Visitor's center at Padre Island National Seashore, Texas in 1982 and 1992. The concrete reinforced structure built on the beach was torn down and a wooden structure was built landward of the dunes. 


\section{Tables}

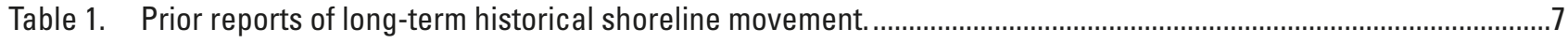

Table 2. Providers and original sources of historical shorelines.

Table 3. Dates of compiled shorelines for selected periods ……...............................................................................

Table 4. List of tide gauge measurements used to calculate mean high water elevation.................................................10

Table 5. Horizontal and vertical differences between high water and mean high water shorelines.................................12

Table 6. Maximum estimated measurement errors for Gulf of Mexico shorelines...............................................................13

Table 7a. Long-term shoreline change trends, 1800s to post-1998.....................................................................................14

Table 7b. Short-term shoreline change trends, 1970s to post-1998.................................................................................

Table 8. Historical hurricane inlet openings and associated surge elevations, west coast of Florida................................21

Table 9. Technical responses to erosion and land loss in the Gulf Coast region................................................................32 


\section{EXECUTIVE SUMMARY}

Beach erosion is a chronic problem along most openocean shores of the United States. As coastal populations continue to grow and community infrastructures are threatened by erosion, there is increased demand for accurate information regarding past and present trends and rates of shoreline movement. There is also a need for a comprehensive analysis of shoreline movement that is consistent from one coastal region to another. To meet these national needs, the U.S. Geological Survey is conducting an analysis of historical shoreline changes along open-ocean sandy shores of the conterminous United States and parts of Hawaii and Alaska. One purpose of this work is to develop standard repeatable methods for mapping and analyzing shoreline movement so that periodic updates regarding coastal erosion and land loss can be made nationally that are systematic and internally consistent.

This report on states bordering the Gulf of Mexico (Florida, Alabama, Mississippi, Louisiana, and Texas) represents the first in a series that will eventually include the Atlantic Coast, Pacific Coast, and parts of Hawaii and Alaska. The report summarizes the methods of analysis, interprets the results, provides explanations regarding the historical and present trends and rates of change, and describes how different coastal communities are responding to coastal erosion. Shoreline change evaluations are based on comparing three historical shorelines with a recent shoreline derived from lidar (Light Detection and Ranging) topographic surveys. The historical shorelines generally represent the following periods: 1800s, 1920s-1930s, and 1970s, whereas the lidar shoreline is 1998-2002. Long-term rates of change are calculated using all four shorelines (1800s to lidar shoreline), whereas shortterm rates of change are calculated for the most recent period (1970s to lidar shoreline). The historical rates of change presented in this report represent past conditions and therefore are not intended for predicting future shoreline positions or rates of change.

Rates of erosion for the Gulf of Mexico region are generally highest in Louisiana along barrier island and headland shores associated with the Mississippi delta. Erosion is also rapid along some barrier islands and headlands in Texas, and barrier islands in Mississippi are migrating laterally. Highest rates of erosion in Florida are generally localized around tidal inlets. The most stable Gulf beaches are along the west coast of Florida where low wave energy and frequent beach nourishment minimize erosion. Some beach segments in Texas have accreted as a result of net longshore drift convergence, and around tidal inlets that have been stabilized by long jetties.

Seawalls and riprap revetments were constructed in all the Gulf Coast states as initial community responses to long- term beach erosion. Although some states, such as Florida, still permit shoreline stabilization structures, beach nourishment has become the preferred method of mitigating longterm erosion.

\section{INTRODUCTION}

\section{U.S. Geological Survey National Assessment of Shoreline Change}

Sandy ocean beaches of the United States represent some of the most popular tourist and recreational destinations, and they also constitute some of the most valuable real estate in the country. These ephemeral interfaces between water and land are the sites of intense residential and commercial development even though they are frequently subjected to natural hazards including flooding, storm impacts, and coastal erosion. Because population centers continue to shift toward the coast where valuable coastal property is vulnerable to erosion, the U.S. Geological Survey (USGS) is conducting a National Assessment of Coastal Change. One aspect of this effort, the National Assessment of Shoreline Change, uses shoreline position as a proxy for coastal change because shoreline position is one of the most commonly monitored indicators of environmental change (Morton, 1996), and it is easily understood by those who are interested in historical movement of beaches.

A principal purpose of the USGS shoreline change research is to develop a repeatable surveying methodology so that shorelines for the continental U.S., and portions of Hawaii, and Alaska can be periodically and systematically updated in an internally consistent manner. In addition, new methods for developing datum based shorelines and assessing coastal change will provide the opportunity to achieve more comprehensive assessments of error in the future. USGS primary objectives of this project are: (1) to develop and implement improved methods of assessing and monitoring shoreline movement, (2) to obtain a better understanding of the processes controlling shoreline movement, and (3) to enter into strategic partnerships to facilitate data dissemination.

Achieving these ongoing long-term objectives requires research that (1) examines the original sources of shoreline data (maps, air photos, global positioning system (GPS), lidar), (2) evaluates the utility of different shoreline proxies (geomorphic feature, water mark, tidal datum, elevation) including the errors associated with each method, (3) investigates the bias and potential errors associated with integrating different shoreline proxies from different sources, (4) develops standard uniform methods of shoreline change analysis, (5) determines the effects of human activities on shoreline movement and rates of change, and (6) investigates alterna- 
tive mathematical methods for calculating historical rates of change and forecasting future rates of change.

This report summarizes historical changes in the Gulf of Mexico shoreline, both accretion and erosion, but emphasizes the erosion hazard because it impacts natural resources and the economy. Shoreline erosion is also presented in the context of coastal land loss http://pubs.usgs.gov/of/2003 of03-337 , which is a much broader issue than beach erosion because it also includes bluff retreat, and erosion and submergence of wetlands around interior bays and estuaries. The brief accounts of coastal land loss for each state provide a more comprehensive view of coastal processes and key references that can be used to learn more about coastal change in a broader context.

\section{Disclaimer}

Results of the National Assessment of Shoreline Change are organized by coastal regions. This report for the Gulf of Mexico region is the first in a series of reports that will include text summarizing methods, results, and implications of the results in addition to maps, via Internet Map Server (IMS), illustrating rates of shoreline change. Rates of shoreline change are being published for the purpose of regional characterization. The shoreline change results and products prepared by the USGS are not intended for comprehensive detailed site specific analysis of shoreline movement, nor are they intended to replace any official sources of shoreline change information identified by local or state government agencies, or other federal entities that are used for regulatory purposes. Rates of shoreline change presented herein may differ from other published rates, but differences do not necessarily indicate that the other rates are inaccurate. Some discrepancies are expected, considering the many possible ways of determining rates of change, and the inherent uncertainty in calculating these rates. Rates of shoreline change presented in this report represent shoreline movement under past conditions. The results are not intended for predicting future shoreline positions or rates of shoreline change.

This publication was prepared by an agency of the United States Government. Neither the United States Government nor any agency thereof, nor any of their employees, makes any warranty, expressed or implied, or assumes any legal responsibility for the accuracy, completeness, or usefulness of any information apparatus, product, or process disclosed in the report, or represents that its use would not infringe privately owned rights. Reference to any specific commercial product, process, or service by trade name, trademark, manufacturer, or otherwise does not necessarily constitute or imply its endorsement, recommendation, or favoring by the United States Government or any agency thereof. Any views and opinions of authors expressed herein do not necessarily state or reflect those of the United States Government or any agency thereof.

\section{Acknowledgments}

This report was made possible by the hard work and generous cooperation of many individuals. We owe a debt of gratitude to Scott Douglass (Alabama), Emmett Foster (Florida), Jim Gibeaut (Texas), Shea Penland (Louisiana), and Barbara Yassin (Mississippi) for providing electronic historical shorelines and accompanying metadata for their respective states, Mike Rink (NOAA) for providing digital historical shorelines and scans of selected T-sheets, David Doyle (NOAA) for providing datum corrections so that T-sheets could be rectified before they were digitized by the USGS, and Matt Stutz (Duke University) for providing information about beach nourishment projects. An enthusiastic and untiring USGS team was responsible for developing the methods and computer codes for calculating operational mean high water elevations and extracting the lidar shorelines. The lidar research and development team included Abby Sallenger, Jeff List, Karen Morgan, Eric Nelson, Hillary Stockdon, and Kathy Webber. Rob Thieler worked closely with TPMC Environmental Services to develop and improve the Digital Shoreline Analysis System (DSAS) code for shoreline change measurement. Kristy Guy spent countless hours testing the DSAS code and suggesting improvements. She also contributed to the layout for the maps depicting rates of shoreline change. Lindsey Kraatz and Heather Kaminsky provided tremendous assistance by digitizing and georectifiying maps and preparing metadata. Betsy Boynton prepared the colorful illustrations, and Valerie Paskevich created the IMS. Critical reviews that greatly improved the technical content and clarity of the report were provided by John Haines, Cheryl Hapke, Jeff List, Bruce Richmond, Peter Ruggiero, Abby Sallenger, and Rob Thieler of the USGS; Spencer Rogers of North Carolina Sea Grant; Jim O'Connell of Woods Hole Oceanographic Institution Sea Grant; Steve Jones and Bob Mink of the Geological Survey of Alabama; Rebecca Beavers of the National Park Service; and Chris Parrish, Maryellen Sault, and Jason Woolard of the National Oceanographic and Atmospheric Administration (NOAA).

\section{THE ROLE OF STATE AND FEDERAL GOVERNMENTS}

One reason for conducting this National Assessment of Shoreline Change is that there is no widely accepted standardized method of analyzing shoreline changes. Each state has its own data needs and coastal zone management responsibilities (eg. construction set-back lines, dune protection zones), and therefore each state uses a different technique and standard to compile shorelines and to calculate rates of shoreline movement. Consequently, calculated rates of shoreline change and projected shoreline positions are inconsistent from state to state and cannot be compared 
directly. These inconsistencies were clearly demonstrated by the Federal Emergency Management Agency (FEMA) sponsored erosion studies (Crowell and Leatherman, 1999) that were used as the basis for evaluating erosion hazards (The Heinz Center, 2000). The USGS National Assessment of Shoreline Change represents the first time that shorelines from original data sources have been compiled and rates of shoreline change have been calculated on a national scale using internally consistent methods. The results of this analysis allow direct comparison of rates of change from one coastal segment to another and form the basis for future comparison of shoreline position.

Several federal agencies (USGS, FEMA, NOAA, U.S. Army Corps of Engineers (USACE)) have regulatory or administrative responsibilities pertaining to shorelines. Yet these responsibilities are quite different, requiring different approaches and offering substantial opportunities for cooperation. For example, the USACE is authorized and funded by Congress to report on the economic and environmental implications of shoreline change and the costs of erosion mitigation. Their National Shoreline Management Study (Stauble and Brumbaugh, 2003) is being conducted using existing shoreline data. The USGS will share data and information, such as the lidar-derived shoreline and rates of change, in support of their effort. NOAA has the mandate to establish the official shoreline boundary for the nation using tidal datums. Their emphasis is on safe navigation and using the shoreline to generate nautical charts. NOAA also has a developing program (V datum), which will greatly assist other agencies in establishing alternative shorelines for a variety of purposes where the official shoreline is inappropriate. Congress authorized and funded FEMA to report on the economic impact of erosion hazards on coastal communities, and on claims to the National Flood Insurance Fund. To accomplish this, FEMA contracted state agencies and academic researchers to conduct a pilot study of erosion hazards that included shoreline change data for limited geographic areas. The USGS is responsible for conducting research pertaining to coastal change hazards including shoreline change, understanding the processes that cause coastal change, and developing models to predict future change. The USGS is the only government agency that has a dedicated program to monitor coastal change into the future using consistent methods nationwide. Such a program is critically important to assess national issues, such as the coastal impacts of sea level rise.

\section{PRIOR NATIONAL AND GULF COAST SHORELINE ASSESSMENTS}

The USACE (1971) conducted the first national assessment of coastal erosion that included the Gulf of Mexico Region. That study identified areas of critical and noncritical erosion on the basis of economic development and potential for property loss, but rates of shoreline movement were not evaluated. Dolan and others (1985) conducted a comprehensive analysis of shoreline changes for the U.S. Their analysis was based on compilation of rates of shoreline change provided by other contributors and derived from their own studies of the middle Atlantic region. Rates of change were presented on maps, and the long-term trends of erosion and accretion were summarized in an accompanying text.

A previous quantitative analysis of shoreline movement that focused entirely on the U.S. shores bordering the Gulf of Mexico was conducted for the Environmental Protection Agency (EPA) Gulf of Mexico Program. From that study, a map entitled "Historical Shoreline Change in the Northern Gulf of Mexico" was published in 1991. The map (scale 1:2,000,000) depicted rates of shoreline change that were prepared by a contributor for each state. The EPA map was revised and reissued in 1996 (Coastal Erosion Subcommittee, 1996). There have been numerous local studies of shoreline movement in each of the Gulf Coast states. Rather than attempting to summarize all of these studies, Table 1 recognizes most statewide or regional studies and provides appropriate references.

Since the work of Dolan and others (1985), methods of obtaining, analyzing, displaying, and storing shoreline data have improved substantially, and coastal change has continued. Furthermore, coastal scientists have not agreed on standard methods for analyzing and reporting shoreline changes, nor have they identified rigorous mathematical tests that are widely accepted for quantifying the change and associated errors. Consequently, there are critical needs for (1) a nationwide compilation of reliable shoreline data including the most recent shoreline position, and (2) a standardization of methods for obtaining and comparing shoreline positions and mathematically analyzing the trends.

\section{METHODS OF ANALYZING SHORELINE CHANGE}

\section{Compilation of Historical Shorelines}

Coastal scientists in universities and government agencies have been quantifying rates of shoreline movement and studying coastal change for decades. Before GPS and lidar technologies were developed, the most commonly used sources of historical shoreline position were NOAA Topographic Sheets (T-sheets, see Shalowitz, 1964) and aerial photographs. Ideally, extraction of shoreline position from these data sources involves geo-referencing and removing distortions from maps or aerial photographs, followed by digitizing shoreline position. Depending on coastal location, data source, and scientific preference, different proxies for shoreline position are used to document coastal change, including the high water line (for discussion of the high water line (HWL) see Shalowitz, 1964), wet-dry line, veg- 
Table 1. Prior reports of quantitative regional analyses of long-term historical shoreline movement that used shorelines derived from T-sheets and aerial photographs.

\begin{tabular}{|c|c|}
\hline Region & References \\
\hline Gulf Coast states & Dolan and others, $1985^{\mathrm{a}}$, Coastal Erosion Subcommittee, 1996; \\
\hline West Florida & Clark, 1991; Dean and others, 1998 \\
\hline Alabama & Hardin and others, 1976, Sanchez and Douglass, 1994 \\
\hline Mississippi & Waller and Malbrough, 1976; Byrnes and others, 1991; \\
\hline Louisiana & Morgan and Larimore, 1957; McBride and others, 1992 \\
\hline Texas & Morton, 1977a; Paine and Morton, 1989; Morton, 1997 \\
\hline
\end{tabular}

${ }^{\text {a }}$ Primarily compilation of rates of change provided by other investigators

${ }^{b}$ Compilation of rates of change provided by state contributors

etation line, dune toe or crest, toe of the beach, cliff base or top, and the line of mean high water (MHWL).

In addition to deriving a modern shoreline from lidar data, the USGS National Assessment of Shoreline Change Project incorporates shoreline positions from pre-existing historical shoreline databases. Numerous organizations and individuals have provided the USGS with digital shoreline data (Table 2). To maintain consistency at a national scale, shorelines from four periods (mid- to late1800s, 1920s1930s, 1970s, and post-1998) were selected for analysis regardless of the number of shorelines available from existing data sets. Any remaining data gaps were filled using scans of historical T-sheets provided by the NOAA Vectorization Project.

Shorelines were compiled for each state following the guidelines established for selected periods (mid- to late 1800s, 1920s-1930s, 1970s, and post-1998) as closely as possible. Table 3 lists the final range of years for shorelines compiled for each period by state. A few notable exceptions include a second-period shoreline for Florida covering years up to 1953, a second-period shoreline for Alabama covering years up to 1957, and a third-period shoreline for Mississippi covering the years 1986-1987. The Florida shoreline incorporates a small segment in West Florida dated 1957 and a few additional segments from the early 1940s due to a lack of alternatives for those specific areas. In Alabama, a 1917 shoreline for the westernmost $8 \mathrm{~km}$ of Dauphin Island was disregarded because the island was severely impacted by a storm in 1917. A 1957 shoreline segment was included as an alternative. The 1980s Mississippi shoreline was selected due to a lack of alternatives closer to the 1970 s period.

\section{Delineation of a Modern (lidar-derived) Shoreline}

The most recent shoreline used in this National Assessment (post-1998) was derived from lidar (light detection and ranging) data. The USGS, in collaboration with NASA, has been using the NASA Airborne Topographic Mapper (ATM) to map coastal areas since 1997 (Krabill and others, 2000; Sallenger and others, 2003). The ATM surveys ground elevation using an elliptically rotating blue-green laser. GPS (global positioning system) positions and inertial navigation systems are used to correct for aircraft pitch, roll, and heading, providing ground elevations with accuracies of about $\pm 15 \mathrm{~cm}$ (Sallenger and others, 2003). Most of the lidar surveys used to extract shorelines for this report were conducted in 2001 (Table 3). This includes the NASA surveys as well as additional lidar data for the Texas coast, which was provided by The University of Texas at Austin Bureau of Economic Geology (Table 2).

To compare with historical shorelines, an operational MHW shoreline was extracted from the lidar surveys using a method developed by Stockdon and others (2002)(Fig. 1). Shorelines were extracted from cross-shore profiles which consist of bands of lidar data 2-4 m wide in the alongshore direction and spaced every $20 \mathrm{~m}$ along the coast. A leastsquares linear regression line is passed through the cluster of data that encompasses the operational MHW datum (Table 4) and is limited to the seaward-sloping beach foreshore. The regression equation is then used to derive the horizontal intersection of the operational MHW datum with the profile, giving the shoreline position for that profile. Repeating this procedure at successive profiles $20 \mathrm{~m}$ apart generates a continuous shoreline.

To determine the operational MHW elevation, the Gulf of Mexico region was divided into 3 subregions. For each subregion, the operational MHW elevation represents an average of MHW elevations from individual open-ocean or 
Table 2. Providers and original sources of historical shorelines for each Gulf Coast state.

\begin{tabular}{|c|c|c|c|}
\hline State & Organization & Original Data Source & Spatial Coverage \\
\hline Texas & $\begin{array}{l}\text { University of Texas at Austin } \\
\text { Bureau of Economic Geology }\end{array}$ & $\begin{array}{l}\text { NOAA T-sheets, aerial } \\
\text { photographs, lidar }\end{array}$ & Entire Coast \\
\hline Louisiana & $\begin{array}{l}\text { University of New Orleans Department of } \\
\text { Geology and Geophysics }\end{array}$ & $\begin{array}{l}\text { NOAA T-sheets, aerial } \\
\text { photographs }\end{array}$ & Entire Coast \\
\hline \multirow{4}{*}{ Alabama } & $\begin{array}{l}\text { University of South Alabama Department } \\
\text { of Civil Engineering }\end{array}$ & T-Sheets & Fort Morgan to Gulf Shores \\
\hline & NOAA Coastal Services Center & Scanned NOAA T-sheets & Dauphin Island \\
\hline & NOAA Vectorization Project & NOAA T-sheets & Entire Coast \\
\hline & Mississippi Office of Geology & Photo and Map Shorelines & Dauphin Island, Fort Morgan \\
\hline \multirow{2}{*}{ Mississippi } & Mississippi Office of Geology & Photo and Map Shorelines & Entire Coast \\
\hline & NOAA Vectorization Project & NOAA T-sheets & Entire Coast \\
\hline \multirow{3}{*}{ Florida } & Department of Environmental Protection, & NOAA T-sheets & Entire Coast \\
\hline & Pinellas County Public Works & NOAA T-sheets & Egmont Key \\
\hline & NOAA Vectorization Project & NOAA T-sheets & $\begin{array}{l}\text { Panhandle: Escambia to Bay County } \\
\text { West Coast: Pinellas to Lee County }\end{array}$ \\
\hline
\end{tabular}

Table 3. Dates of compiled shorelines for selected periods.

\begin{tabular}{|l|c|c|c|c|}
\hline \multirow{2}{*}{ State } & \multicolumn{4}{|c|}{ Selected Periods } \\
\cline { 2 - 5 } & mid- to late- 1800s & 1920s - 1930s & 1970s & post-1998 \\
\hline Florida & $1855-1895$ & $1926-1953$ & $1976-1979$ & $1998-2001$ \\
\hline Alabama & $1849-1867$ & $1918-1957$ & $1978-1981$ & 2001 \\
\hline Mississippi & 1850 & 1917 & $1986-1987$ & 2001 \\
\hline Louisiana & $1855-1887$ & $1922-1934$ & $1973-1978$ & 2001 \\
\hline Texas & $1850-1883$ & $1930-1938$ & $1970-1975$ & $2000-2001$ \\
\hline
\end{tabular}

near open-ocean tide gauges. A list of tide gauges and MHW elevations used in each subregion is presented in Table 4. The lidar-extracted MHW shoreline is not the same as a MHW shoreline surveyed by a licensed land surveyor. This is because the operational MHW elevation used for the lidar shoreline is an average of the MHW elevations at several tide gauges. Furthermore, the lidar-extracted shoreline is intended only as a reference feature for measuring shoreline change. It is not intended to establish legal boundaries.
Because wetlands generally are not suitable sites for extraction of a lidar shoreline, extensive wetland areas such as the mangrove swamps of south Florida, Big Bend marsh of Florida, and much of the Mississippi delta were not included in the shoreline change analysis. Also, lidar surveys were not available for sandy beaches in west Florida from Cape Romano to Sanibel Island, and along the chenier plain in southwestern Louisiana. When lidar data are available for these gaps, the shoreline change analyses will be conducted and provided in future reports and as on-line updates. 

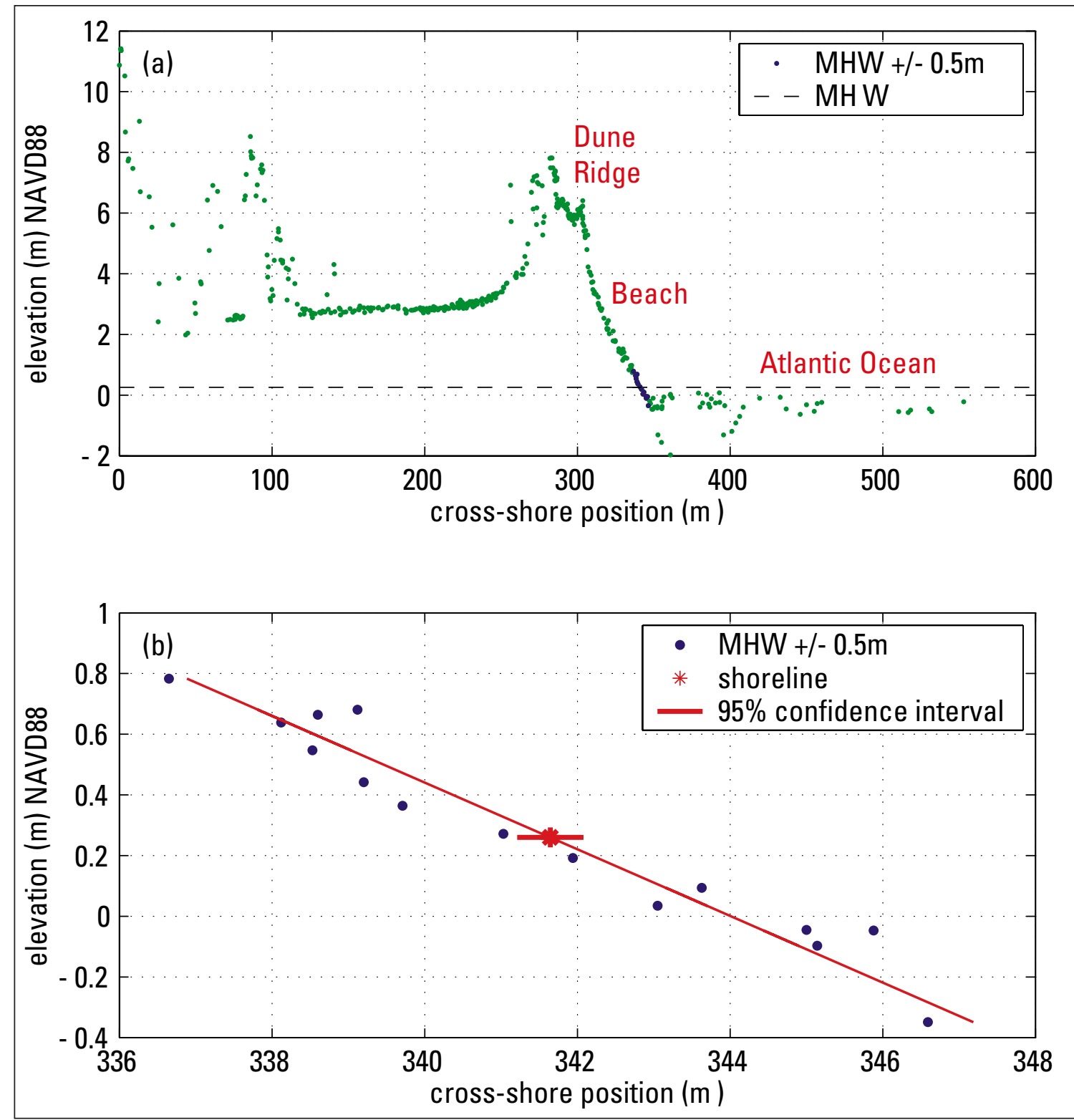

Figure 1. Example of a lidar profile from September 26, 1997 at Kitty Hawk, North Carolina for (a) the entire crossshore region and (b) an expanded view of the foreshore region. (a) Laser returns off of the water's surface are seen as the noisy signal seaward of $x=350 \mathrm{~m}$. Bold symbols indicate data points within $\pm 0.5 \mathrm{~m}$ of the operational MHW datum. (b) The asterisk marks the cross-shore position of the shoreline on the foreshore. The horizontal error bar represents the $95 \%$ confidence interval about the estimate. From Stockdon and others (2002).

\section{Geographic Information System (GIS) Procedures}

Digital shorelines for each selected period were compiled as ESRI ArcView shapefiles and a quality assessment was performed. Shoreline gaps for each period were identified and NOAA T-sheet indexes were used to determine T-sheet availability for those areas. T-sheets were then requested from NOAA and received as scanned TIF images.

T-sheets were rectified using Erdas Imagine geographic imaging software by placing at least 6 well-spaced ground control points (GCPs) on selected T-sheet graticules in geographic coordinates. Some T-sheets produced before 1930 required additional coordinate transformation information from NOAA to convert from the United States Standard Datum (USSD) to the North American Datum of 1927 (NAD27). The datum transformation was applied to T-sheet graticule coordinates prior to rectification. Total Root Mean Square (RMS) error for the rectification process was maintained below 1 pixel, which is approximately $4 \mathrm{~m}$ at a scale of 1:20,000 and approximately $1.5 \mathrm{~m}$ at a scale of 1:10,000. Typically the resulting RMS was much lower than one pixel. Newly geo-referenced T-sheets were loaded in ArcView 
Table 4. List of tide gauge measurements used to calculate mean high water elevation.

\begin{tabular}{|l|c|c|}
\hline \multicolumn{1}{|c|}{ Site Name } & $\begin{array}{c}\text { MHW above NAVD88 } \\
\text { (m) }\end{array}$ & $\begin{array}{c}\text { Average of MHW } \\
(\mathbf{m})\end{array}$ \\
\hline Corpus Christi, TX & 0.281 & 0.37 \\
Galveston Pleasure Pier, TX & 0.369 & \\
Grand Isle, LA & 0.468 & \\
\hline Gulfport Harbor, MS & 0.318 & \\
Dauphin Island, AL & 0.24 & 0.23 \\
Navarre Beach, FL & 0.22 & \\
St. Andrews State Park, FL & 0.216 & \\
Mexico Beach, FL & 0.18 & \\
Cape San Blas, FL & 0.16 & \\
Alligator Point, FL & 0.27 & \\
\hline Baileys Bluff, FL & 0.17 & \\
Clearwater Beach, FL & 0.14 & \\
Indian Rocks Beach, FL & 0.09 & \\
St. Petersburg Beach, FL & 0.065 & \\
Venice, FL & 0.067 & \\
Captiva Island, FL & 0.024 & \\
Naples, FL & 0.09 & \\
Marco Island, FL & 0.11 & \\
\hline
\end{tabular}

and shorelines were digitized. Completed shoreline vectors were finally converted to the Universal Transverse Mercator (UTM) projection with the North American Datum of 1983 (NAD83).

Shorelines from all sources were merged to produce a single shoreline for each of the 4 time periods by state. Final shorelines were coded with 6 attribute fields (ID, Type, Date, Description, Source, and Accuracy) to prepare for calculating shoreline change rates with the Digital Shoreline Analysis System (DSAS). The attributes include the original survey year in the Date field and the source of the data in the Source field.

\section{Calculation and Presentation of Rates of Change}

Rates of long-term shoreline change were generated in a GIS with the Digital Shoreline Analysis System (DSAS) version 2.0, an ArcView extension developed by the USGS in cooperation with TPMC Environmental Services. The extension is designed to efficiently lead a user through the major steps of shoreline change analysis. This extension to ArcView contains three main components that define a baseline, generate orthogonal transects at a user-defined separation along the coast, and calculate rates of change (linear regression, endpoint rate, average of rates, average of endpoints, jackknife). The extension utilizes the Avenue code to develop transects and rates, and uses the Avenue programming environment to automate and customize the user interface.

Baselines were constructed seaward of, and parallel to, the general trend of the four shorelines. Using DSAS, transects were spaced $50 \mathrm{~m}$ apart. Transects were manually eliminated to prevent calculation of rates in areas where less than four shorelines were intersected. Fewer than four shorelines can result from one or more of the following conditions (Fig. 2): 1) an inlet eliminated one or more of the shorelines, 2) shoreline segments were missing (data gaps), 3) a barrier island migrated laterally (no overlap of shorelines and/or misrepresentation of rates), 4) a shoreline disappeared over time.

Long-term rates of shoreline change were calculated at each transect using linear regression applied to all four shoreline positions from the earliest (1800s) to the most recent (derived from lidar). Linear regression was selected because it has been shown to be the most statistically robust quantitative method when a limited number of shorelines are available (Crowell and others, 1997). It is also the most commonly applied statistical technique for expressing shoreline movement and estimating rates of change (Crowell and Leatherman, 1999). Short-term rates of shoreline change were calculated using the endpoint method comparing the 1970s and most recent (lidar-derived) shoreline positions. Long-term rates and short-term rates of shoreline change, as defined here, are used throughout the report. 


\section{A Inlet Openings}

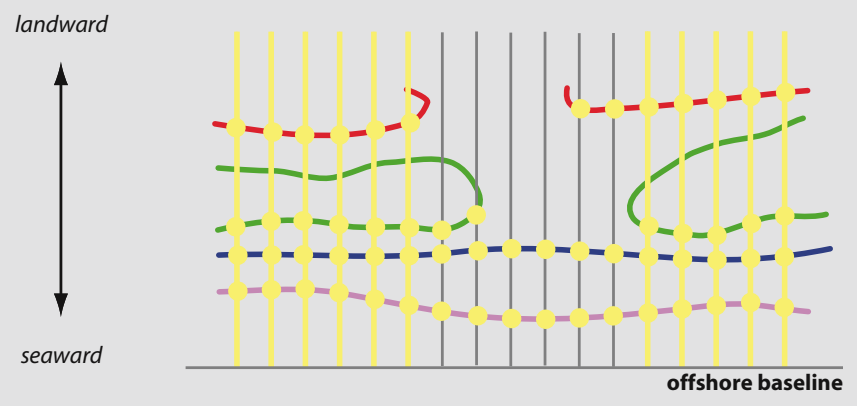

\section{B Missing Data}

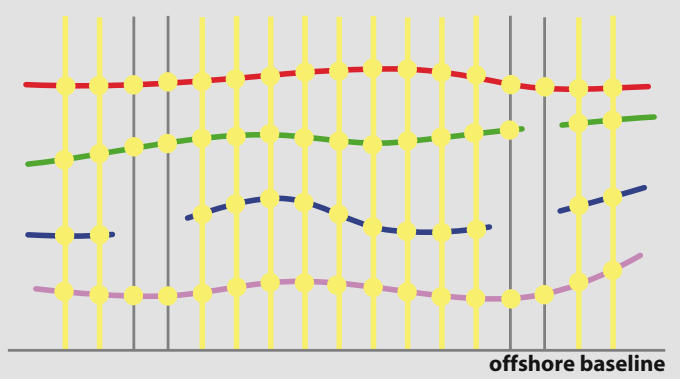

\section{Barrier Migration}

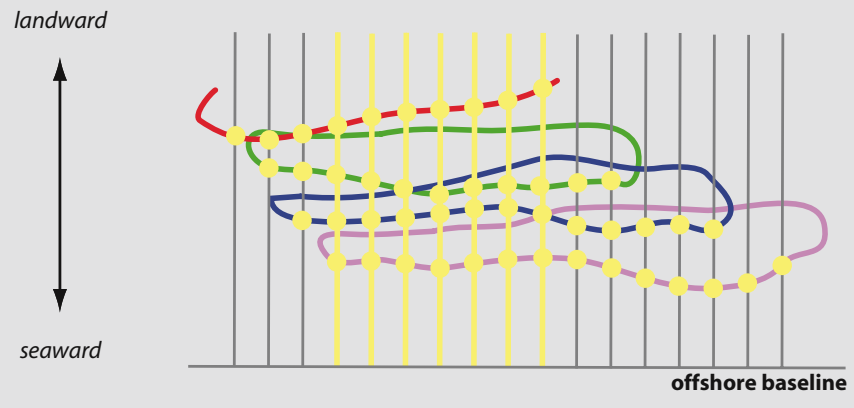

D Shoreline Loss

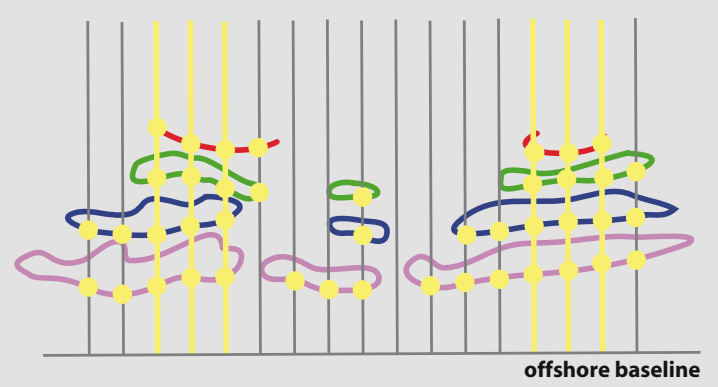

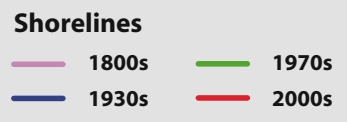

Transects

used for calculation

eliminated transect/shoreline intersection

Figure 2. Examples of common conditions where transects are eliminated in the absence of four shoreline intersections.

Both long-term and short-term rates of shoreline change calculated for each transect (50 $\mathrm{m}$ alongshore spacing) were color coded according to class interval with green colors indicating accretion and red colors indicating erosion. The shoreline change rates and individual shoreline data layers were compiled into an ArcIMS, or Arc Internet Map Server, viewable at http://coastalmap.marine.usgs.gov.

\section{Shoreline Definitions and Beach Alterations that Influence Rates of Change}

\section{Shoreline Definitions}

Inclusion of a lidar-derived shoreline represents a new approach to the investigation of shoreline change. The three pre-lidar historical shorelines come from topographic maps and aerial photographs that use the HWL as the shoreline proxy. For more than 150 years the HWL has served as the authoritative shoreline because it could be visually identified in the field. With advanced technologies, such as GPS and lidar, it is possible to define the shoreline on the basis of an elevation or a tidal datum, such as MHW. Changing the shoreline definition from a physical feature that is uncontrolled in terms of an elevation datum to a shoreline defined by an elevation has important implications with regard to inferred changes in shoreline position and calculated rates of change.

Published and unpublished data were compiled to evaluate the horizontal and vertical differences in HWL determined from beach profiles, aerial photographs, or GPS surveys, and the MHWL derived from beach profiles, GPS surveys, or lidar surveys (Table 5). The HWL and MHWL positions were established at the same time, or within a few weeks of one another at multiple sites around the U.S. where the beach and wave characteristics are diverse. Comparing these HWL and MHWL positions assumes that the observed offsets are entirely artifacts of shoreline definition and are not related to actual changes in the beach profile between the survey dates. This is a relatively safe assumption considering the short intervals between surveys or the knowledge that a particular shoreline segment is relatively stable.

Table 5 shows that average absolute horizontal and vertical offsets between the HWL and MHWL range from a few meters to more than $50 \mathrm{~m}$, and vertical offsets can be as much as $2 \mathrm{~m}$. Most of the horizontal offsets are less than 20 
Table 5. Absolute horizontal and vertical differences between high water and mean high water shorelines.

\begin{tabular}{|c|c|c|c|c|c|c|c|c|}
\hline Location & $\begin{array}{c}\text { Survey Date } \\
\text { HWL }\end{array}$ & $\begin{array}{c}\text { Survey } \\
\text { Date } \\
\text { MHWL }\end{array}$ & $\begin{array}{c}\text { Length of } \\
\text { Shore } \\
(\mathrm{km})\end{array}$ & $\begin{array}{c}\text { Number of } \\
\text { Observations }\end{array}$ & $\begin{array}{c}\text { Average } \\
\text { Horizontal } \\
\text { Offset } \\
\text { (m) }\end{array}$ & $\begin{array}{c}\text { Average } \\
\text { Vertical } \\
\text { Offset } \\
\text { (m) }\end{array}$ & $\begin{array}{c}\% \text { MHWL } \\
\text { with } \\
\text { Seaward } \\
\text { Offset }\end{array}$ & Data Source or Reference \\
\hline Galveston Is., TX' & $01-27-95$ & $01-27-95$ & Point & 1 & 18 & 0.6 & 100 & \multirow{5}{*}{ Morton and Speed, 1998} \\
\hline \multirow{4}{*}{ North Padre Is., TX' } & $08-16-95$ & 08-16-95 & 1.6 & 6 & 8 & 0.4 & 100 & \\
\hline & $09-14-95$ & $09-14-95$ & 1.6 & 6 & 8 & 0.2 & 100 & \\
\hline & $09-28-95$ & $09-28-95$ & 1.6 & 6 & 12 & 0.2 & 100 & \\
\hline & $10-06-95$ & $10-06-95$ & 1.6 & 6 & 6 & 0.3 & 100 & \\
\hline Duck, NC ${ }^{2}$ & \multicolumn{2}{|c|}{$1994-1996^{2}$} & Point & 111 & 40 & 2.0 & 100 & Pajak and Leatherman, 2002 \\
\hline \multirow{2}{*}{ Klipsan, WA ${ }^{3}$} & 05-26-99 & 05-28-99 & 3.0 & 171 & 22 & 0.5 & 100 & \multirow{6}{*}{ Ruggiero and others, 2003} \\
\hline & $09-21-99$ & 09-24-99 & 3.0 & 171 & 52 & 0.8 & 100 & \\
\hline \multirow{3}{*}{ Ocean Shores, $W^{3}$} & $05-26-99$ & $05-28-99$ & 4.0 & 200 & 23 & 1.0 & 100 & \\
\hline & $07-27-99$ & $07-22-99$ & 4.0 & 200 & 8 & 0.2 & 100 & \\
\hline & $05-06-01$ & 05-07-01 & 4.0 & 200 & 30 & 1.0 & 100 & \\
\hline Oysterville, WA ${ }^{3}$ & $09-21-99$ & $09-10-99$ & 3.5 & 201 & 49 & 0.9 & 100 & \\
\hline \multirow{4}{*}{ Assateague Is., MD/ VA ${ }^{4}$} & $03-16-98$ \& 03-17-98 & $04-03-98$ & 58.6 & 1172 & 11 & 0.7 & 99 & \multirow{3}{*}{ National Park Service (M. Duffy) } \\
\hline & $09-29-99 \& 10-28-99$ & $10-01-99$ & 60.0 & 1200 & 20 & 1.6 & 100 & \\
\hline & $06-13-01 \&$ 06-14-01 & 06-05-01 & 52.4 & 1049 & 8 & 0.6 & 92 & \\
\hline & $10-01-02$ & $09-12-02$ & 47.7 & 953 & 22 & 1.4 & 98 & Coastal Research and Engineering, Inc. (M. Byrnes) \\
\hline
\end{tabular}

${ }^{1}$ Simultaneous measurement of HWL and MHWL at beach profiles coordinated with tide gauge measurements

${ }^{2}$ Video camera projections of HWL for 111 days during a three-year period and MHWL from generalized beach profiles

${ }^{3}$ Nearly simultaneous aerial photographs (HWL) and GPS surveys (MHWL)

${ }^{4}$ Nearly simultaneous GPS (HWL) and lidar surveys (MHWL)

$\mathrm{m}$, and most of the vertical offsets are less than $1 \mathrm{~m}$. Offsets are greatest on relatively flat beaches where high waves produce high wave runup (southwest Washington). Conversely, offsets are least where beaches are relatively steep and wave runup is low (west coast of Florida). Because breaking waves run up on the beach, the MHWL is most commonly seaward of the HWL (Morton and Speed, 1998). For the data we analyzed, the MHWL was seaward of the HWL at more than $90 \%$ of the transects (Table 5). Because we are using a MHWL shoreline for the latest period, this nearly systematic horizontal offset between the HWL and the MHWL could cause shoreline positions and calculated rates of change to imply slower erosion, a change from erosion to accretion, or faster accretion depending on actual changes at a given site.

\section{Human Activities}

Attempts to stabilize the shore can also greatly influence the rates of shoreline change. Activities such as beach nourishment or emplacement of shoreline stabilization structures tend to alter coastal processes, sediment transport, and shoreline position. For example, beach nourishment artificially causes rapid, temporary shoreline accretion. Depending on the frequency of beach nourishment, the placement of large volumes of sand on the beach will bias the rates of observed shoreline change toward accretion or stability, even though the natural beach, in the absence of nourishment, would be eroding.

Trembanis and Pilkey (1998) prepared a summary of identifiable beach nourishment projects in the Gulf Coast region that had been conducted before 1996. These records were used to identify shoreline segments that had been influenced by beach nourishment. Additional information regarding beach nourishment was provided by Steve Jones of the Alabama Geological Survey, Scott Douglass of the University of South Alabama, and Ralph Clark of the Florida Department of Environmental Protection. Only projects that pre-date the lidar shoreline were included. There is no distinction made between large volume, continuous projects and small volume, finite projects. According to Trembanis and Pilkey (1998), beaches along the west coast of Florida are some of the most frequently nourished beaches in the U.S. The frequent nourishment is reflected in the slow rates of shoreline retreat or stability, even though the natural rates of erosion may be higher. Differentiating between natural rates of erosion and the influences of beach nourishment is difficult because experiments have not been conducted to specifically address this issue. In addition, available data may be inadequate to address this issue because there are not enough shoreline positions immediately before, after, and between nourishment projects. Human responses to coastal erosion in each state, including beach nourishment and emplacement of structures, are discussed in more detail in a later section.

\section{Reliability of the Results}

Documented trends and calculated rates of shoreline change are only as reliable as: (1) measurement errors that determine the accuracy of each shoreline position, (2) sampling errors that account for the variability of shoreline posi- 
Table 6. Maximum estimated measurement errors for Gulf of Mexico shorelines.

\begin{tabular}{|c|c|c|c|c|}
\hline \multirow{2}{*}{ Measurement Errors $(\mathbf{m})$} & \multicolumn{5}{|c|}{ Time Period $^{*}$} \\
\cline { 2 - 5 } & $\mathbf{1}$ & $\mathbf{2}$ & $\mathbf{3}$ & $\mathbf{4}$ \\
\hline Rectification error $\left(\mathrm{E}_{\mathrm{r}}\right)$ & 4 & 4 & 4 & 0 \\
\hline Digitizing error $\left(\mathrm{E}_{\mathrm{d}}\right)$ & 1 & 1 & 1 & 0 \\
\hline T-sheet survey error $\left(\mathrm{E}_{\mathrm{t}}\right)$ & 10 & 10 & 0 & 0 \\
\hline Shoreline proxy offset $\left(\mathrm{E}_{\mathrm{o}}\right)$ & 0 & 0 & 0 & 18 \\
\hline Lidar position error $\left(\mathrm{E}_{\mathrm{l}}\right)$ & 0 & 0 & 0 & 1.5 \\
\hline & & & & \\
\hline Total shoreline position error $\left(\mathrm{E}_{\mathrm{sp}}\right)(\mathbf{m})$ & 10.8 & 10.8 & 4.1 & 18.1 \\
\hline Annualized transect error $\left(\mathrm{E}_{\mathrm{a}}\right)(\mathbf{m} / \mathbf{y r})$ & \multicolumn{5}{|c|}{0.2} \\
\hline
\end{tabular}

*Time periods: 1=1800s; 2=1920s-1930s; 3=1970s; 4=post-1995

tion, and (3) statistical errors associated with compiling and comparing shoreline positions. Anders and Byrnes (1991), Crowell and others (1991), Thieler and Danforth (1994), and Moore (2000), provided general estimates of the typical measurement errors associated with mapping methods and materials for historical shorelines, registry of shoreline position relative to geographic coordinates, and shoreline digitizing. The largest errors were positioning errors of $\pm 10 \mathrm{~m}$, which were attributed to scales and inaccuracies in the original surveys (T-sheets and aerial photographs). However, the influence of large shoreline position errors on long-term rates of change can be reduced because the period of analysis is so long ( $>100 \mathrm{yrs}$ ). Stockdon and others (2002) provided estimates of GPS positioning errors $( \pm 1 \mathrm{~m})$ and regression errors $( \pm 1.5 \mathrm{~m})$ associated with shorelines derived from lidar data.

Estimates of the maximum measurement errors for this study are provided in Table 6 to show how each error contributes to uncertainty in the shoreline position and in the rates of change. A total shoreline position error $\left(\mathrm{E}_{\mathrm{sp}}\right)($ equation 1) incorporates all of the measurement errors by taking the square root of the sum of the squares of: rectification error $\left(E_{r}\right)$, digitizing error $\left(E_{d}\right)$, T-sheet survey error $\left(E_{t}\right)$, shoreline proxy offset $\left(E_{o}\right)$, and lidar position error $\left(E_{1}\right)$. Rectification error represents the elected maximum acceptable RMS error for T-sheets at a scale of 1:20,000 in this study. We assume data from outside sources conforms to similar standards. The rectification error is applied to the historical shorelines only. Digitizing error reflects the maximum digitizing error specified in past studies (Anders and Byrnes, 1991; Crowell and others, 1991; Moore, 2000). The digitizing error is applied to the historical shorelines only. The maximum T-sheet survey error, determined by Shalowitz (1964), incorporates all of the errors associated with the mapping process including distance to rodded points, plane table position, and identification of the HWL. The T-sheet survey error is applied only to historical shorelines from time periods 1 and 2 (1800s shoreline and 1920-1930s shoreline, respectively), as it is assumed that more recent shorelines are derived from aerial photos or other sources. The shoreline proxy offset reflects the maximum horizontal offset between high water and mean high water shorelines in the Gulf of Mexico (see Table 5). The offset error pertains only to the lidar-derived shoreline. Lidar position error reflects the maximum error associated with the derivation of a lidar shoreline (Stockdon and others, 2002). The lidar position error is applied only to the lidar-derived shoreline. Thus, total shoreline position error is expressed by equation 1 :

$$
E_{s p}=\sqrt{E_{r}{ }^{2}+E_{d}{ }^{2}+E_{t}^{2}+E_{o}^{2}+E_{l}^{2}}
$$

A separate $\mathrm{E}_{\mathrm{sp}}$ can be calculated for each period. Finally, the position errors for each period can be incorporated into an error for each transect. That value can be annualized to provide an error estimation for the shoreline change rate at any given transect. The annualized error $\left(\mathrm{E}_{\mathrm{a}}\right)$ is expressed by equation 2 :

$$
E_{a}=\frac{\sqrt{E_{s p 1}{ }^{2}+E_{s p 2}{ }^{2}+E_{s p 3}{ }^{2}+E_{s p 4}{ }^{2}}}{\text { time }}
$$

The maximum annualized error using best estimates for Gulf of Mexico shorelines is $0.2 \mathrm{~m} / \mathrm{yr}$ (Table 6).

Sampling errors relating to the local short-term variability of true shoreline positions (Morton, 1991; Douglas and Crowell, 2000) are less well known. Temporally dense data are required to evaluate short-term shoreline variability resulting from seasonal cycles and from rapid storm erosion and subsequent recovery. Moreover, most data sets include some apparent shoreline movement caused by changes in water level (HWL) and not changes in sediment volume (Morton, 1991). Lack of reliable high frequency data regarding short-term variability of true shoreline position at most coastal sites limits the ability to quantify and incorporate the associated uncertainty into the overall shoreline position uncertainty. An exception is the 20-year record of beach profiles surveyed by the COE at Duck, N.C. Using 460 shoreline positions from the Duck profile data, Barton and 
others (2003) showed that the envelope (range) of shoreline positions even around a relatively stable shoreline was about $\pm 20 \mathrm{~m}$.

Linear regression is the most commonly applied statistical technique for expressing shoreline movement and estimating rates of change (Crowell and Leatherman, 1999). Linear regression assumes linear behavior, which technically is incorrect (Morton, 1991; Barton and others, 2003), but is adequate for a first approximation. Because linear regression fails to recognize the potential for temporal differences in trend (trend reversals) and accelerations or decelerations (Morton, 1991; 1996), average trends and rates of shoreline change in this study were calculated for long-term (entire period) and short-term (most recent) time scales. Long-term rates of shoreline change were determined at each transect by taking the slope of the regression line applied to all four shoreline positions. The resulting rate is reported in units of $\mathrm{m} / \mathrm{yr}$ (Table 7). Uncertainties for the long-term rates ( \pm values in Table 7 ) are also reported in units of $\mathrm{m} / \mathrm{yr}$. The reported uncertainties represent a $90 \%$ confidence interval for the slope of the regression line. This means with $90 \%$ statistical confidence that the true rate of shoreline change falls within the range defined by the reported value plus or minus the error value. The variability around the trend line reflects both measurement and sampling errors.

Field observations and prior studies of shoreline movement within each State bordering the Gulf of Mexico (Table 1) suggest that the trends and relative rates of change presented in this study are reasonably accurate. Reliability of the mapped results increases as both the persistence of the trend and rates of change increase. Stated another way, confidence in the analytical results is greatest where the rates of shoreline erosion or accretion are high and the trend has persisted for decades. On the other hand, confidence in the absolute results decreases where the shoreline is relatively stable and the rates of change are low. This is because minor differences in historical or lidar shoreline positions can alter substantially the regression line and the calculated results. Data confidence also decreases in areas where frequent trends reversals occur.

Advanced technology such as GPS and lidar can better constrain shoreline positions, reduce the methodological errors, and improve the accuracy (reduce the error) of future historical shorelines. Establishing a datum-based shoreline (lidar derived MHWL) as the standard for comparison provides, for the first time, the ability to perform an error analysis that is both quantitative and meaningful, in terms of its application. In the future, each electronic MHWL shoreline could be presented with an accompanying error bar that would define the alongshore envelope of confidence. Subsequent shorelines and associated confidence envelopes would provide a more precise basis for determining the statistical significance of observed shoreline change. Unfortunately, the use of lidar or any other shoreline mapping technology will still require distinguishing between short-term variability in shoreline position and the long-term trend of shoreline change.

\section{GEOMORPHOLOGY OF THE GULF COAST REGION}

The Gulf Coast region encompasses west Florida, Alabama, Mississippi, Louisiana, and Texas (Fig. 3). This lowlying area comprises a variety of coastal features including mainland shores, bays and lagoons, deltaic plains, chenier plains, barrier islands and peninsulas, and tidal inlets (Fig. 4). The physical characteristics and geologic framework of each of these features partly determine the trends and rates of shoreline movement and related coastal changes of the region. In the following descriptions, the numbers in parentheses following a geographic location or feature refer to Figure 3.

Table 7a. Long-term shoreline change trends, derived from linear regression rates using four shorelines.

\begin{tabular}{|c|c|c|c|c|c|c|c|c|}
\hline \multirow[b]{2}{*}{ State } & \multirow[b]{2}{*}{ Number of Transects } & \multirow{2}{*}{$\begin{array}{l}\text { Mean Shoreline Change } \\
\text { Rate }(\mathrm{m} / \mathrm{yr})\end{array}$} & \multirow[b]{2}{*}{$\%$ Erosion } & \multicolumn{2}{|c|}{ Erosion Rates (m/yr) } & \multirow[b]{2}{*}{$\%$ Accretion } & \multicolumn{2}{|c|}{ Accretion Rates $(\mathrm{m} / \mathrm{yr})$} \\
\hline & & & & Max & Mean & & Max & Mean \\
\hline Florida & 10,644 & $-0.1 \pm 0.1$ & 58 & $-7.7 \pm 3.4$ & $-0.8 \pm 0.9$ & 42 & $7.6 \pm 8.5$ & $0.9 \pm 1.2$ \\
\hline Alabama & 1,294 & $-0.4 \pm 0.8$ & 75 & $-2.8 \pm 1.9$ & $-0.8 \pm 0.8$ & 25 & $2.2 \pm 0.5$ & $0.5 \pm 0.9$ \\
\hline Mississippi & 724 & $-2.3 \pm 1.9$ & 80 & $-13.5 \pm 3.3$ & $-3.1 \pm 1.8$ & 20 & $3.0 \pm 3.1$ & $1.0 \pm 2.2$ \\
\hline Louisiana & 2,490 & $-7.1 \pm 4.5$ & 91 & $-36.8 \pm 14.2$ & $-8.2 \pm 4.4$ & 9 & $7.2 \pm 12.0$ & $2.5 \pm 5.2$ \\
\hline Texas & 10,626 & $-0.7 \pm 1.7$ & 64 & $-9.2 \pm 5.1$ & $-1.8 \pm 1.3$ & 36 & $14.9 \pm 18.6$ & $1.2 \pm 2.4$ \\
\hline
\end{tabular}

Table 7b. Short-term shoreline change trends, derived from end-point rates using two recent shorelines.

\begin{tabular}{|c|c|c|c|c|c|c|c|c|}
\hline \multirow[b]{2}{*}{ State } & \multirow[b]{2}{*}{ Number of Transects } & \multirow{2}{*}{$\begin{array}{c}\text { Mean Shoreline Change } \\
\text { Rate (m/yr) }\end{array}$} & \multirow[b]{2}{*}{$\%$ Erosion } & \multicolumn{2}{|c|}{ Erosion Rates (m/yr) } & \multirow[b]{2}{*}{$\%$ Accretion } & \multicolumn{2}{|c|}{ Accretion Rates (m/yr) } \\
\hline & & & & Max & Mean & & Max & Mean \\
\hline Florida & 11,116 & 0.2 & 54 & -21.3 & -1.5 & 46 & 37.3 & 2.2 \\
\hline Alabama & 1,466 & 0.3 & 42 & -9.2 & -1.5 & 58 & 10.4 & 1.5 \\
\hline Mississippi & 968 & -2.1 & 63 & -46.4 & -5.8 & 37 & 19.4 & 4.4 \\
\hline Louisiana & 2,924 & -10.1 & 88 & -78.6 & -12.0 & 12 & 19.1 & 3.9 \\
\hline Texas & 10,912 & -0.1 & 48 & -25.1 & -2.6 & 52 & 48.2 & 2.2 \\
\hline
\end{tabular}




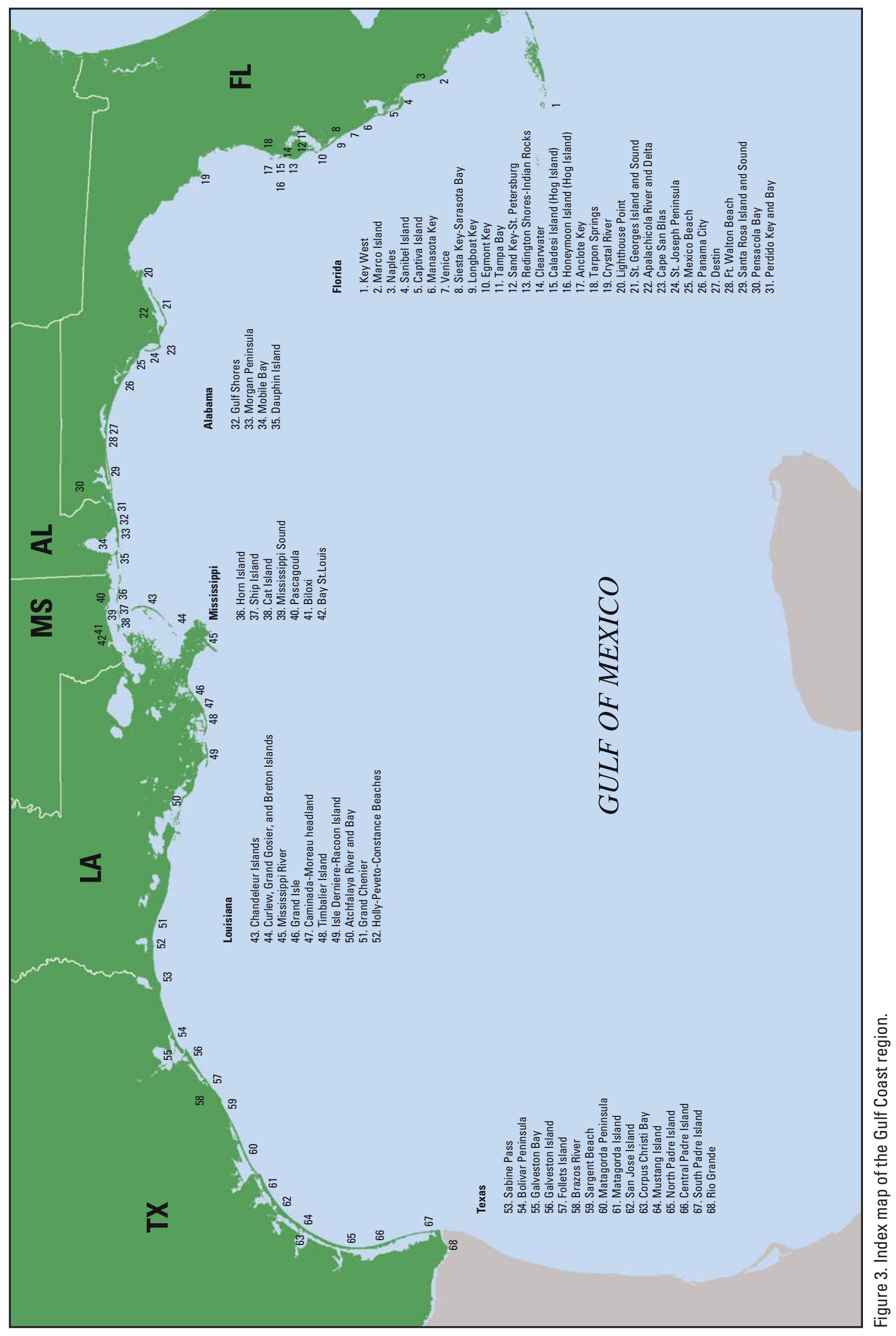




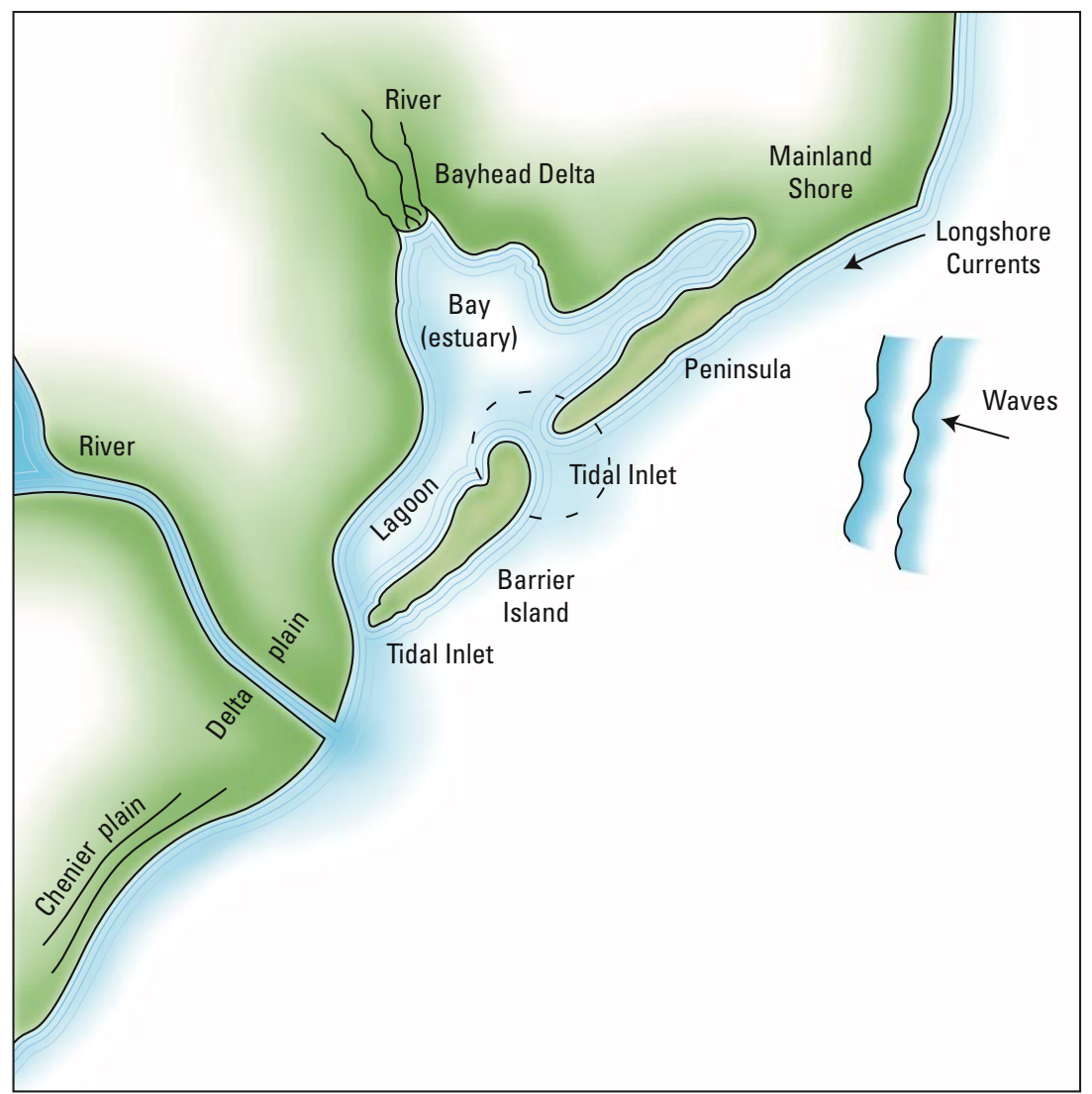

Figure 4. Common coastal landforms of the Gulf Coast region.

\section{Gulf of Mexico Mainland Shores}

The U.S. coast bordering the Gulf of Mexico consists mainly of barrier islands, but there are some segments where the mainland shore meets the Gulf without an intervening bay or lagoon. For example, in Florida sandy mainland shores are exposed to Gulf waves near Mexico Beach (25), Venice (7), and Naples (3); a sandy bluff shore extends from Panama City (26) to Ft. Walton Beach (28); and a marsh shore is found from Tarpon Springs (18) to Apalachicola (22). The only mainland shore in Alabama is a sandy stretch of beach near Gulf Shores (32). In Mississippi, sandy and marsh mainland shores extend from Pascagoula (40) westward to the Louisiana state line. There are mainland shores along the Caminada-Moreau headland (47) and chenier plain (51) of southwestern Louisiana. In Texas, Gulf mainland shores are located between Sabine Pass (53) and Bolivar Peninsula (54), between Follets Island (57) and Matagorda Peninsula (60), and near the mouth of the Rio Grande (68). The mainland Gulf shores in Louisiana and Texas generally are locally underlain with mud and the beaches are narrow.

\section{Bays and Lagoons}

Most large coastal bays bordering the Gulf of Mexico are drowned river valleys that have remained unfilled because the rivers emptying into the bays are transporting very little sediment. Bays are oriented perpendicular to the Gulf shoreline, whereas lagoons are parallel to the Gulf shoreline. Some lagoons are locally named bays or sounds such as Sarasota Bay, Florida (8) and Santa Rosa Sound, Florida (29). The coastal lagoons formed when the uplands between the river valleys were flooded by rising sea level, so the lagoons separate the barrier islands from the mainland.

Bay and lagoon shores account for the longest stretches of eroding shoreline (Smith, 1990; Doyle and others, 1984; Canis and others, 1985; Morton and Paine, 1990; Penland and others, 1990). They are also the most complex in terms of land loss because they have different orientations and relief, and they cut across sediments with different elevations and resistance to erosion. Bay shores can be composed of sand, shell, or mud and they can form low beaches, tall bluffs, or marshes. Analyses of shoreline changes in bays and lagoons are not included because the focus of this report is on the Gulf shoreline.

\section{Barrier Islands}

\section{Origin and Evolution of Barriers}

The origins and related morphologies of barrier islands can influence shoreline movement because the thicknesses 


\section{A. Dune Drowning}

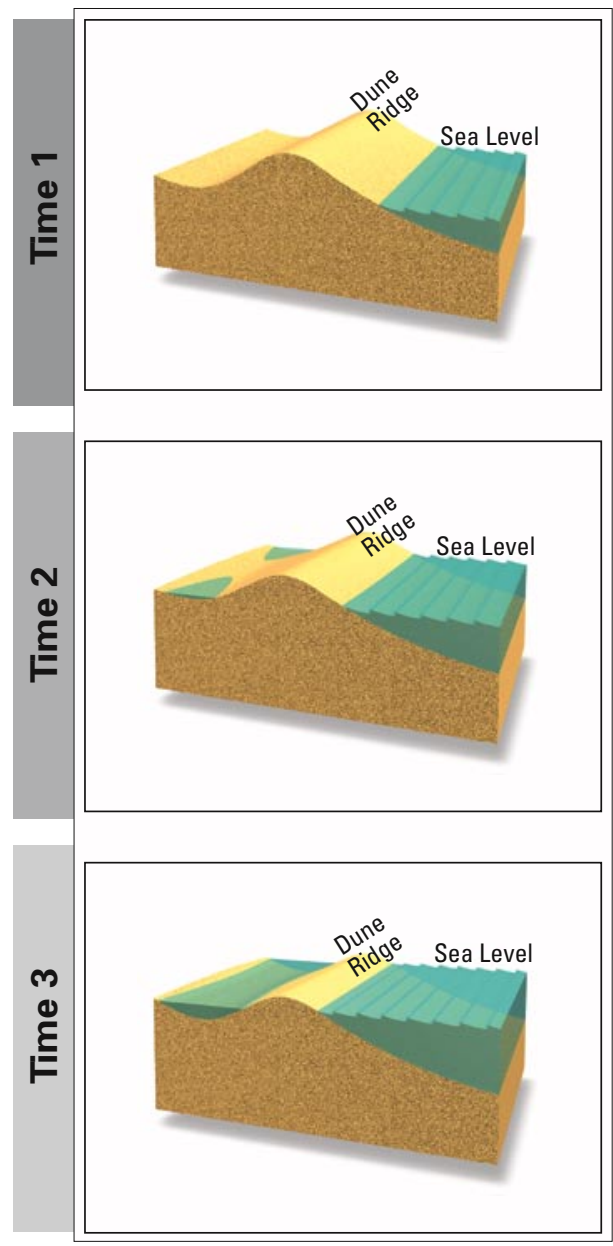

B. Spit Accretion

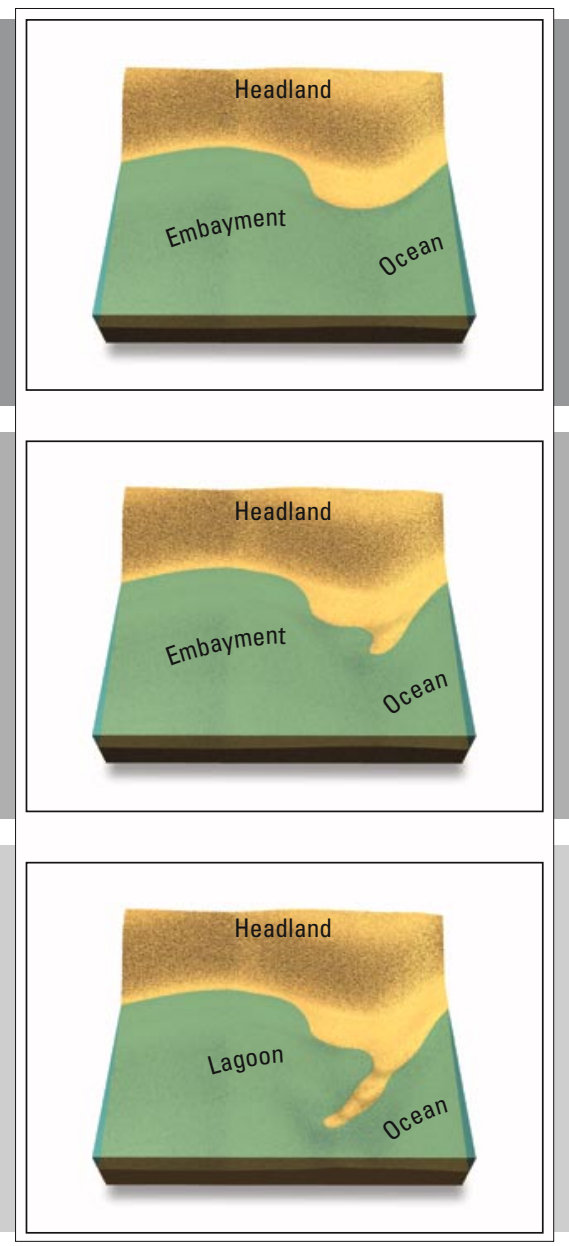

\section{Shoal Emergence}

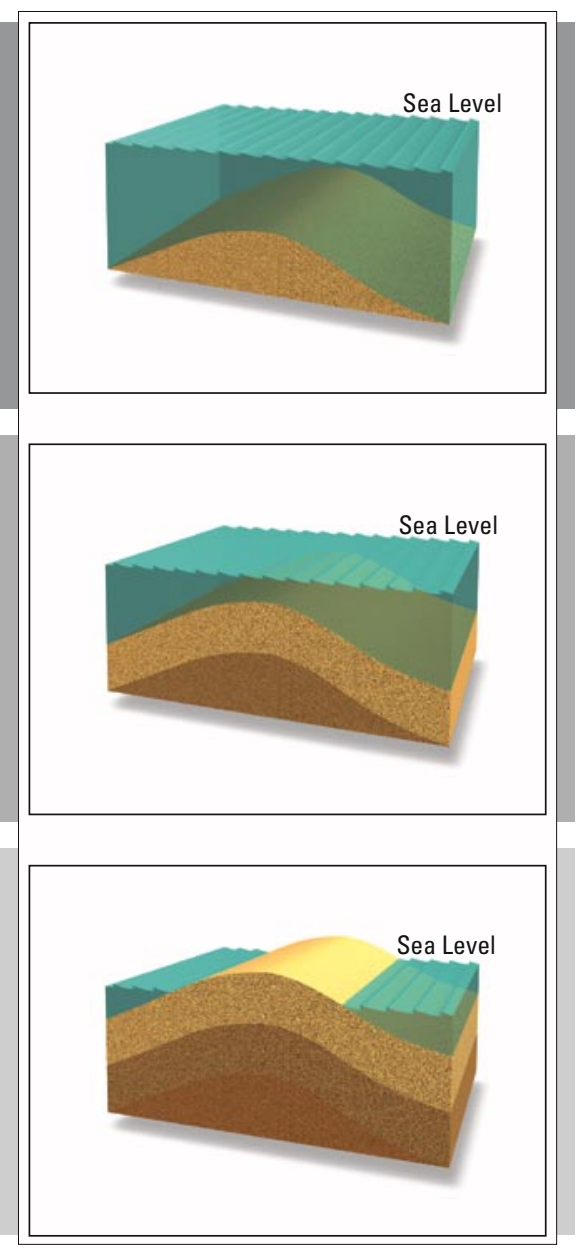

Figure 5. Conceptual diagram showing possible origins of barrier islands.

and volumes of sand stored in the barriers are related to the processes that formed them. Barrier islands commonly form the outer fringes of low-lying coastal plains throughout the world. As their name implies, they are surrounded by water and are separated from the adjacent mainland by lagoons, bays, or marshes and from neighboring islands by tidal inlets. Barrier islands are long and narrow mounds of sand deposited by waves and wind over millenia. In general, they are produced by long-term submergence of the lowgradient coast. Three independent mechanisms (Fig. 5) have been proposed for the origins of barrier islands: (1) dune drowning (McGee, 1890), (2) spit accretion (Gilbert, 1885), and (3) shoal emergence (De Beaumont, 1845). Each mechanism explains the origin of some barriers (Hoyt, 1967), but no single cause explains the origins of all barriers (Schwartz, 1971).

Barrier islands can form by dune drowning (Fig. 5A) when a relative rise in sea level partly inundates the mainland ridge of coastal dunes. The rising water encompasses the sand dunes along the beach and eventually floods the seaward sloping coastal plain between the dunes and upland, forming a lagoon.
Spit accretion (Fig. 5B) refers to lateral barrier extension along the prevailing trend of the beach. Sand transported along the coast by longshore currents is deposited on the flanks of headlands or at the downdrift ends of existing barrier islands. Spit accretion is a widely observed process whereby barriers are originally constructed across embayments forming lagoons, or previously formed barriers are enlarged in a downdrift direction. Recurved beach ridges are diagnostic field evidence of spit accretion. This type of barrier formation generally occurs under stable sea-level conditions and/or a surplus of sand supply.

Shoal emergence (Fig. 5C) involves the upward growth of a submerged bar where sand is supplied by erosion and redistribution of sediment on the sea floor. The vertical accumulation of sand causes the bar to eventually rise above the ocean level so that the emergent bar forms a barrier island. Shoal emergence is aided by a slight lowering of relative sea level, such as after a storm, and it also requires a local surplus of sand to maintain the barrier.

All three origin scenarios are represented in the barriers of the northern Gulf of Mexico. Many of the barriers (Sanibel Island, Florida (4); Horn Island, Mississippi (36); 


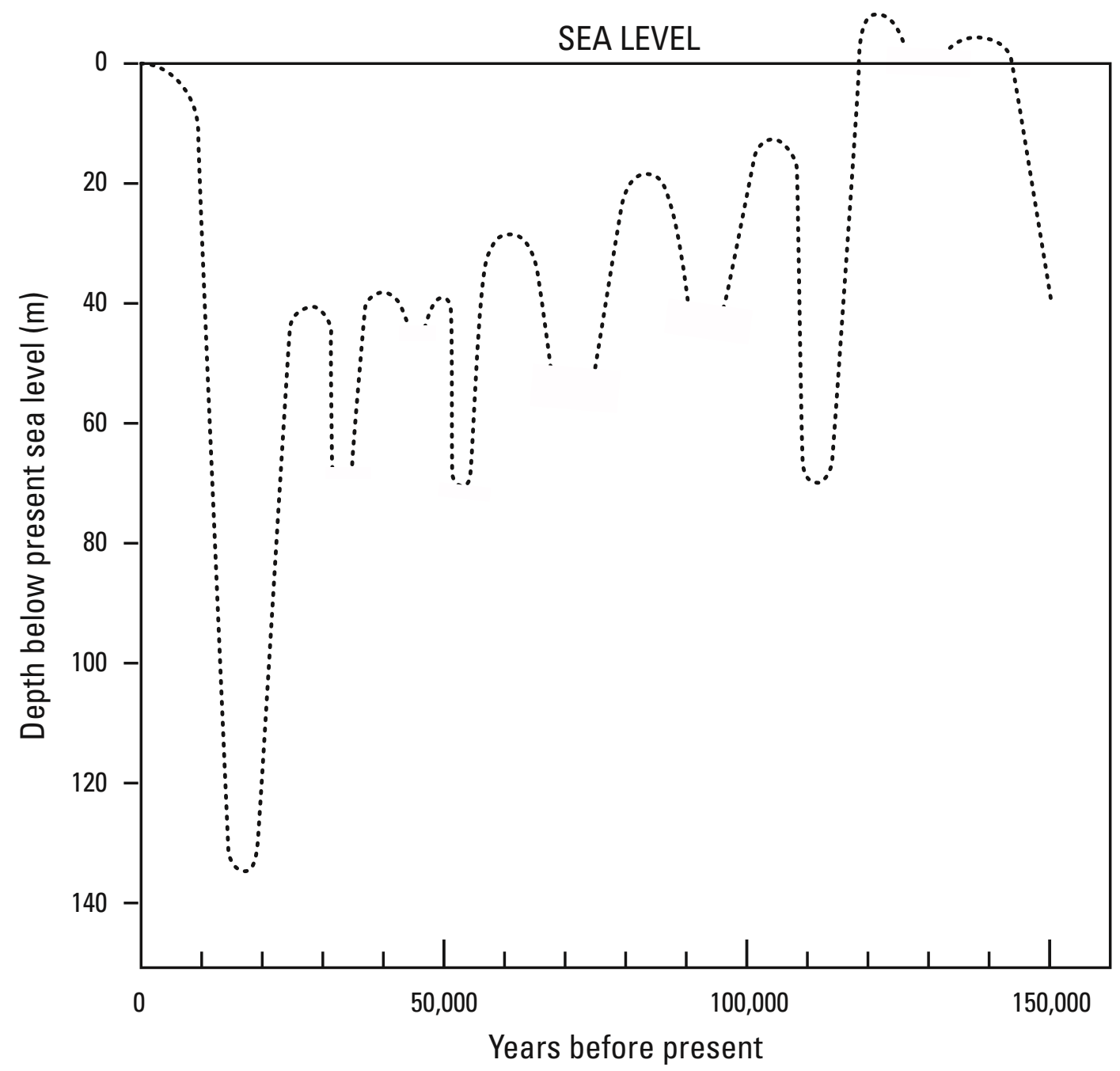

Figure 6. Sea level curve during the past 150,000 years that depicts the general magnitude and timing of sea level changes in the Gulf of Mexico. Modified from Moore (1982).

Galveston Island, Texas (56)) were originally migrating across the continental shelf and then began to grow seaward when the rise in sea level slowed about 5,000 years ago (Fig. 6). Some barriers have grown laterally as spits attached to the mainland shore (St. Joseph Peninsula, Florida (24); Bolivar Peninsula, Texas (54)) and other barriers formed around an island core of older barrier deposits left over from a previous time when sea level was at about the same level as today (east Dauphin Island (35) and Morgan Peninsula (33), Alabama). Still other barriers (Mississippi Sound (39) barriers and Anclote Key, Florida (17)) may have emerged from offshore sand shoals (Otvos, 1979; Davis and others 1985). This upbuilding of barriers occurs most commonly in shallow water where wave energy is low, where the slope of the continental shelf is very gentle, and where a rapid accumulation of sand deposited by storms can drastically alter nearshore currents and wave patterns. These conditions are particularly applicable to the west coast of Florida.

Today the highest barrier elevations and largest sand dunes are present on the sand-rich aggradational (upward building) and progradational (seaward building) barrier islands such as Central Padre Island, Texas (66); east Dauphin Island, Alabama (35); and St. Joseph Peninsula, Florida (24). Much of the coastal sand that was washed ashore as sea level reached its present position is stored in these high-profile barriers (Fig. 7) and they typically have lower erosion rates because of the abundant sand. Migrating and landward retreating barriers, such as St. George Island, Florida (21); Chandeleur Islands, Louisiana (43); and South Padre Island, Texas (67), typically have higher erosion rates because they are located away from major sources of sand.

\section{Morphologies of Gulf Coast Barrier Islands}

Barrier islands make up more than two-thirds of the northern Gulf of Mexico shore. Each of the barriers is either high-profile or low-profile (Fig. 7) depending on the elevations and morphology of the island. The height and continuity of these elevations determine the ability of the barriers to withstand storm surge flooding and overwash. The origins 


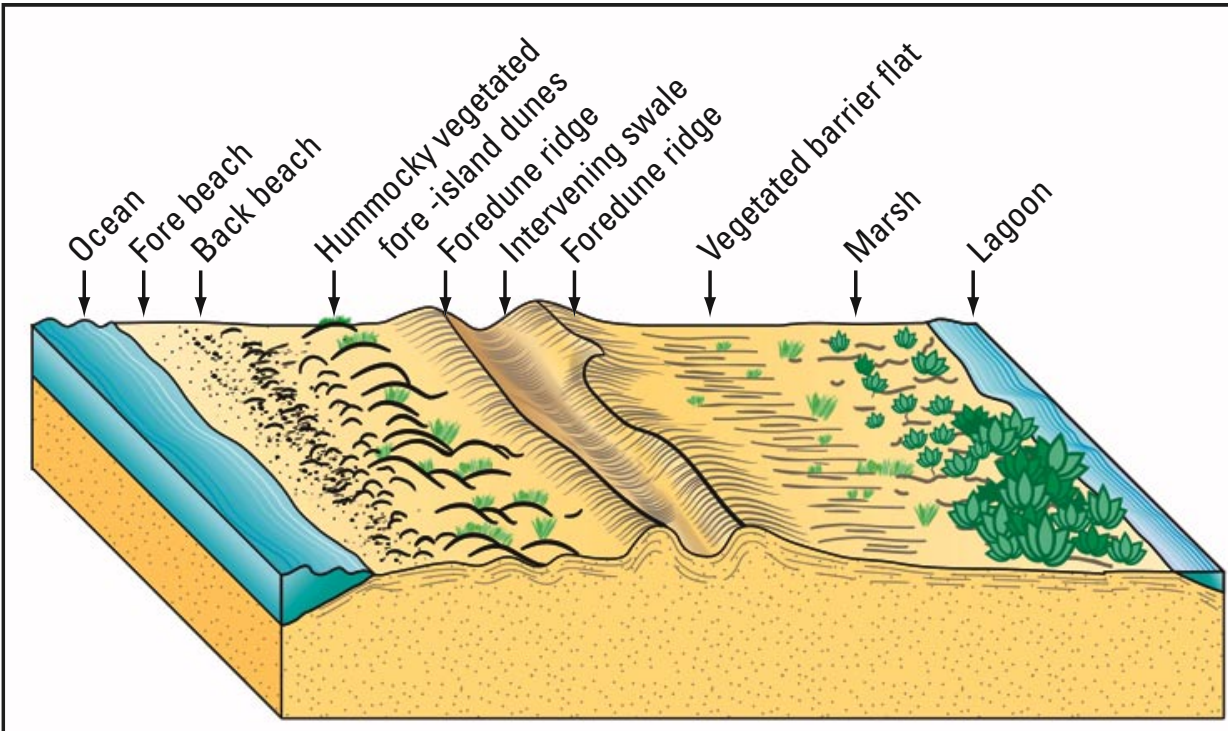

High-Profile Barrier Island

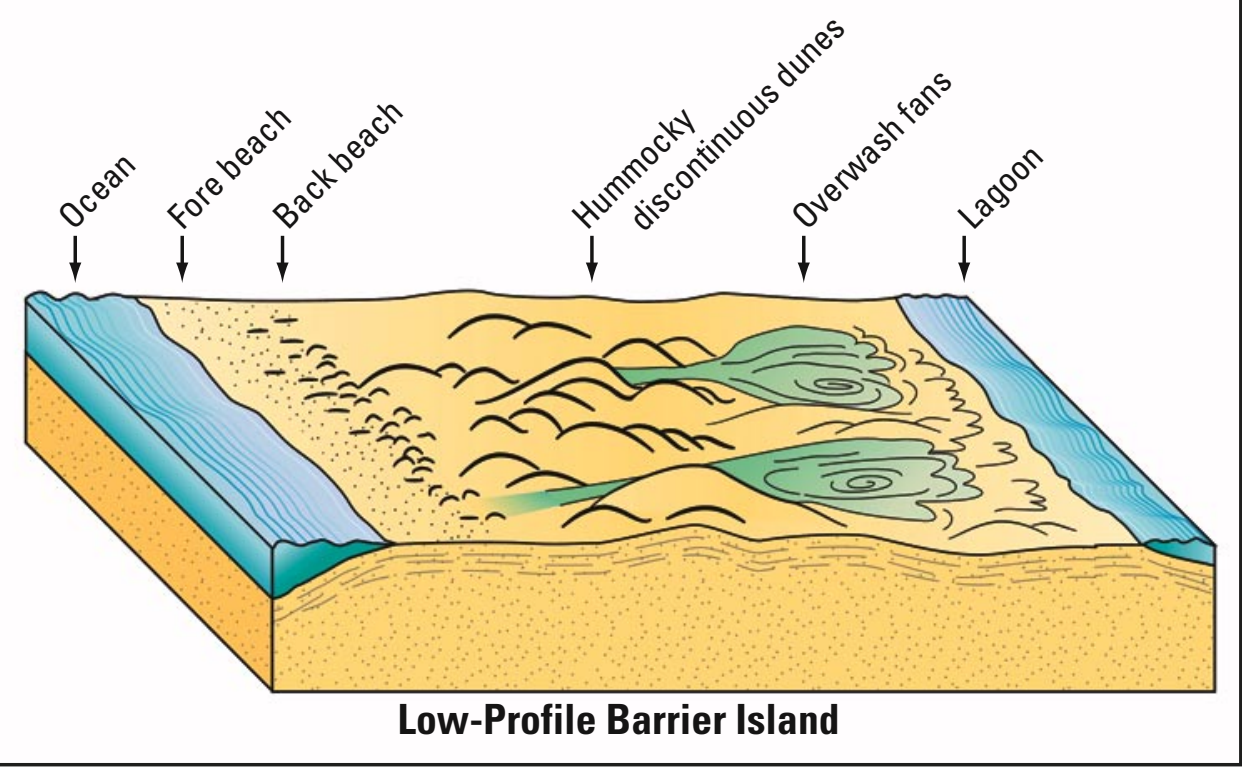

Figure 7. Geomorphological characteristics of high and low profile barrier islands. Modified from White and others (1978).

and profiles of the barriers also partly determine the stability of the shoreline (Morton, 1979).

Low-profile barriers, such as South Padre Island, Texas (67), the Chandeleur Islands of Louisiana (43), western Dauphin Island, Alabama (35), and St. George Island, Florida (21), are typically narrow and characterized by discontinuous frontal dunes that are lower than and inundated by extreme storm surges. This makes the entire barrier subject to frequent overwash during storms. Overwash also creates channels and fans that transfer sand from the ocean onto the barrier or into the adjacent lagoon. Barrier upbuilding is a response to a rise in relative sea level, and the transfer of sand from the ocean to the lagoon is how the barrier migrates landward and still retains its general shape and sand volume. Island migration is enhanced if there is a deficit in the sand supply or if there is a rapid rise in relative sea level. However, if the rate of sea level rise is too great, then the barrier island is drowned in place and left as a submerged sand shoal on the continental shelf.

High-profile barriers, such as Sanibel Island, Florida (4), Matagorda Island, Texas (61), and Central Padre Island, Texas (66) are the result of abundant sand supply for thousands of years. These barriers are typically wide and have continuous, well-vegetated dune ridges. The high elevations effectively block storm surges and prevent island overwash, even during the most severe storms. For high-profile barriers, enough sand is stored in the dunes that they are able to withstand prolonged erosion without being breached, which 
would allow flooding of the barrier core. However, flooding of high-profile barriers can occur from the lagoon side or from the ocean through artificial breaks in the dune ridge, such as beach access roads or areas where dunes have been destroyed by coastal construction.

\section{Chenier Plain}

The chenier plain of southwestern Louisiana and southeastern Texas (51-53) is the western extension of the Mississippi delta. It consists of topographically high beach ridges composed of sand and shell separated by low swales of marsh filled with muddy organic-rich sediments (Gould and McFarlan, 1959). The sandy beach ridges represent periods of slow delta construction and possibly slightly higher sea levels when the coastal plain sediments were reworked by waves and concentrated along the shore. The intervening swales represent periods of mud deposition and delta advancement when the supply and accumulation of muddy sediments was greater than the erosional capacity of the waves. Although the chenier plain was actively prograding several hundred years ago, the shore is presently eroding.

\section{Tidal Inlets}

Tidal inlets, also referred to as passes, are the primary channels separating the barrier islands (Fig. 4). They also allow the exchange of water and migration of marine organisms between the Gulf and adjacent bays. Shorelines near unstabilized inlets are commonly sites of high variability and rapid erosion due to inlet migration and high current velocities. Long-term rates of change and their associated uncertainties at sites near inlets can be useful in conveying the variable nature of the shoreline and the derived risks from a coastal hazards perspective. For this study, some of this variability may be minimized in the rates and uncertainties around inlets because of the decision to maintain consistent routines by deleting transects in cases where less than four shorelines were present.

Most large inlets are used for navigation into and out of the coastal bays and ports. These navigable inlets have been modified for maintenance of deep-draft shipping channels, and many of the channels are lined by long, rock jetties. Where they are unmodified, sand banks and beaches line the inlets. Several man-made inlets through Gulf Coast barrier islands have altered water circulation patterns, longshore currents, and littoral drift and have locally caused or contributed to both beach erosion and accretion (Morton, 1977b; Dean and O'Brian, 1987).

Some tidal inlets are opened during storms and remain open for long periods. For example, in 1969 Hurricane Camille breached Ship Island, Mississippi (37), forming Camille Cut, and the 1926 hurricane opened Hurricane Pass between Caladesi Island (15) and Honeymoon Island (16), Florida (Davis, 1994). Barrier breaching commonly reoc- curs after narrow spits or peninsulas attach to headlands. Breaching is also common where substantial downdrift inlet migration has over time produced a low barrier segment and a long ebb channel that is hydrodynamically inefficient.

Long, narrow microtidal barrier island segments that have low relief (maximum dune elevations of less than 2 $\mathrm{m}$ ) and that are far from existing tidal inlets are the most susceptible to breaching and new inlet construction during inundation by an extreme storm. Inlet formation may occur when fast moving hurricanes tracking near the coast produce oceanic storm surges that exceed the dune heights. When there is insufficient time for lagoon water levels to respond to elevated open ocean water levels, a hydraulic head can be created driving flows landward across the narrow barrier and incising channels (Morton, 2002). The west coast of Florida has been the site of numerous historical inlet openings or reactivation of closed inlets and is particularly vulnerable to this extreme storm response (Table 8).

\section{GEOLOGIC HISTORY AND SETTING}

River deltas, marshes, and barrier islands built the broad coastal plain bordering the northern Gulf of Mexico during two periods when sea level was relatively high. The highest coastal plain elevations were formed about 130,000 years ago during a late Pleistocene interglacial period when sea level was about 6 to $8 \mathrm{~m}$ higher than today (Fig. 6). The lower coastal plain elevations associated with modern marshes and barrier islands formed when sea level reached its present position about 5,000 years ago. Between these periods, the shape and origin of the present Gulf Coast was greatly influenced by changes in sea level due to expansion and melting of continental glaciers. The present-day shape of the Gulf Coast, and the origin of many of the distinctive coastal features found today, reflects these fluctuations in sea level that alternately exposed and submerged the coastal plain.

About 18,000 years ago, at the end of the last glacial epoch, sea level was about $130 \mathrm{~m}$ lower than today (Fig. 6). This lower sea level caused coastal plain rivers to cut deep valleys across the continental shelf. As the glaciers melted and sea level rose to its current position, these valleys were drowned and most were only partly filled with sediment. The unfilled remnants of former river valleys that rim the Gulf of Mexico are the major bays, such as Galveston Bay, Mobile Bay, and Pensacola Bay. Only large rivers, such as the Rio Grande and Brazos River in Texas, the Mississippi River in Louisiana, and the Apalachicola River in Florida carried enough sediment to fill their valleys and build deltas into the Gulf of Mexico.

Post-glacial changes from a cooler and wetter climate to today's warmer and drier conditions had dramatic effects on the amount of water and sediment transported by the coastal plain rivers draining into the Gulf of Mexico. As rainfall decreased so did stream flow and sediment load, 
Table 8. Historical hurricane inlet openings and associated surge elevations, west coast of Florida. Information regarding inlet openings and closings is summarized in Davis and Gibeaut (1990) and Barnard (1998). Storm categories (Saffir-Simpson scale), rankings, and surge elevations are from National Hurricane Center archives and the U.S. Army Corps of Engineers (1984). Rank refers to the intensity of each hurricane compared to the most intense hurricanes of record. NR is not ranked. Quadrant refers to geographic location with respect to the storms center. RF is right front (looking onshore) where the storm surge is greatest. Flood and ebb refer to the direction of water flowing onshore (flood) or offshore (ebb) from the shoreline.

\begin{tabular}{|l|c|c|c|c|c|c|c|}
\hline Storm Date & Inlet Name & Barrier Segment & $\begin{array}{c}\text { Barrier } \\
\text { Width } \\
(\mathbf{m})\end{array}$ & $\begin{array}{c}\text { Nearest } \\
\mathbf{I n l e t} \\
\mathbf{( k m )}\end{array}$ & $\begin{array}{c}\text { Category/ } \\
\text { Rank }\end{array}$ & $\begin{array}{c}\text { Max. } \\
\text { Surge } \\
\text { (m) }\end{array}$ & $\begin{array}{c}\text { Storm } \\
\text { Quadrant }\end{array}$ \\
\hline Sept. 1848 & Johns Pass & Sand Key & 125 & 5.5 & NR & 4.6 & $?$ \\
\hline Sept. 1848 & New Pass & Longboat Key & 200 & 5.0 & NR & 4.6 & RF flood \\
\hline Oct. 1921 & Hurricane Pass & Hog Island & 150 & 4.5 & $3 / 39$ & 2.9 & RF flood \\
\hline Oct. 1921 & Midnight Pass & Siesta Key & 120 & 9.5 & $3 / 39$ & 2.1 & RF flood \\
\hline Oct. 1921 & Redfish Pass & Captiva Island & 50 & 6.1 & $3 / 39$ & 2.0 & RF flood \\
\hline Oct. 1926 & unnamed & Indian Rocks & 75 & 1.6 & $4 / 12$ & -1.8 & RF ebb \\
\hline Elena 1985 & Willy's Cut & Caladesi Island & 100 & 0.9 & $3 / 56$ & 1.5 & RF flood \\
\hline
\end{tabular}

which caused some river deltas (Rio Grande and Brazos in Texas) to retreat (Morton, 1979). While the deltas were retreating, some adjacent beaches and barrier islands that had been migrating landward began to build seaward as a result of locally abundant sand supply. The sand that built the accreting shores was supplied by erosion of adjacent deltas or mainland shores and reworking of Pleistocene barrier islands that were submerged on the continental shelf by the rising sea. Numerous beach ridges that mark successive former positions of the Gulf shoreline at Sanibel Island, Florida; Morgan Peninsula, Alabama; Cat Island, Mississippi; and San Jose Island, Texas (Fig. 8), and many other islands, are evidence of the abundant supply of older sand.

\section{Climate}

Differences in rainfall distribution along the Gulf Coast create a distinct east-to-west climatic gradient that is reflected in the vegetation and geologic processes of each sub-region. From Florida to southeast Texas, annual rainfall is abundant and the climate is subhumid. Here salt-water marshes are widespread, maritime forests occupy the higher coastal elevations, and eolian processes are limited in their capacity to modify the landscape. At the dry end of the spectrum are the semi-arid conditions of South Padre Island, Texas where evapo-transpiration exceeds precipitation. In areas of low rainfall, salt-water marshes are rare, forests are absent, grasses are the climax vegetation on barrier islands, and large active dunes cover the landscape, signifying the importance of eolian processes. On average, the amount of rainfall and evaporation are about equal near Corpus Christi, Texas. Areas south and west of Corpus Christi are susceptible to prolonged droughts that weaken or kill the vegetation and create large active dune fields (Fig. 9). From a beach erosion perspective, these dune fields represent vast quantities of sand that are derived from the beach, transported across the barrier islands, and deposited either in the adjacent lagoons or on the mainland forming a vast sheet of wind-blown sand.

\section{Coastal Processes}

The Gulf Coast is a microtidal (less than $0.5 \mathrm{~m}$ tidal amplitude) storm-dominated region that is constantly changing as a result of active coastal processes that are directly linked to meteorological events. Wind-driven waves and currents are the most important geological agents controlling sediment transport and evolution of the Gulf shores. Wind directions and intensities vary seasonally with southerly winds prevailing most of the year. During the winter months, wind-circulation patterns and low barometric pressures preceding the passage of cold fronts cause strong onshore winds and high waves that typically erode the beach. After each frontal system passes the coast, wind direction shifts and strong northerly winds can generate waves that erode the backbarrier shores at many locations.

Astronomical tides in the Gulf of Mexico are diurnal or mixed and typically have a range of less than $1 \mathrm{~m}$. Water levels vary only about $0.5 \mathrm{~m}$ between high and low tide during an average tidal cycle. Tide records around the Gulf since the turn of the century all show the same general variations in sea level (Fig. 10). Annual variations are controlled by meteorological and oceanographic factors (Hicks, 1968), some of which coincide with droughts and periods of abnormally high rainfall (Morton, 1994). Averaging of the tide records shows that some areas, such as the west coast of Florida, are relatively stable because the underlying hard limestone substrates are stable. Other tide records 


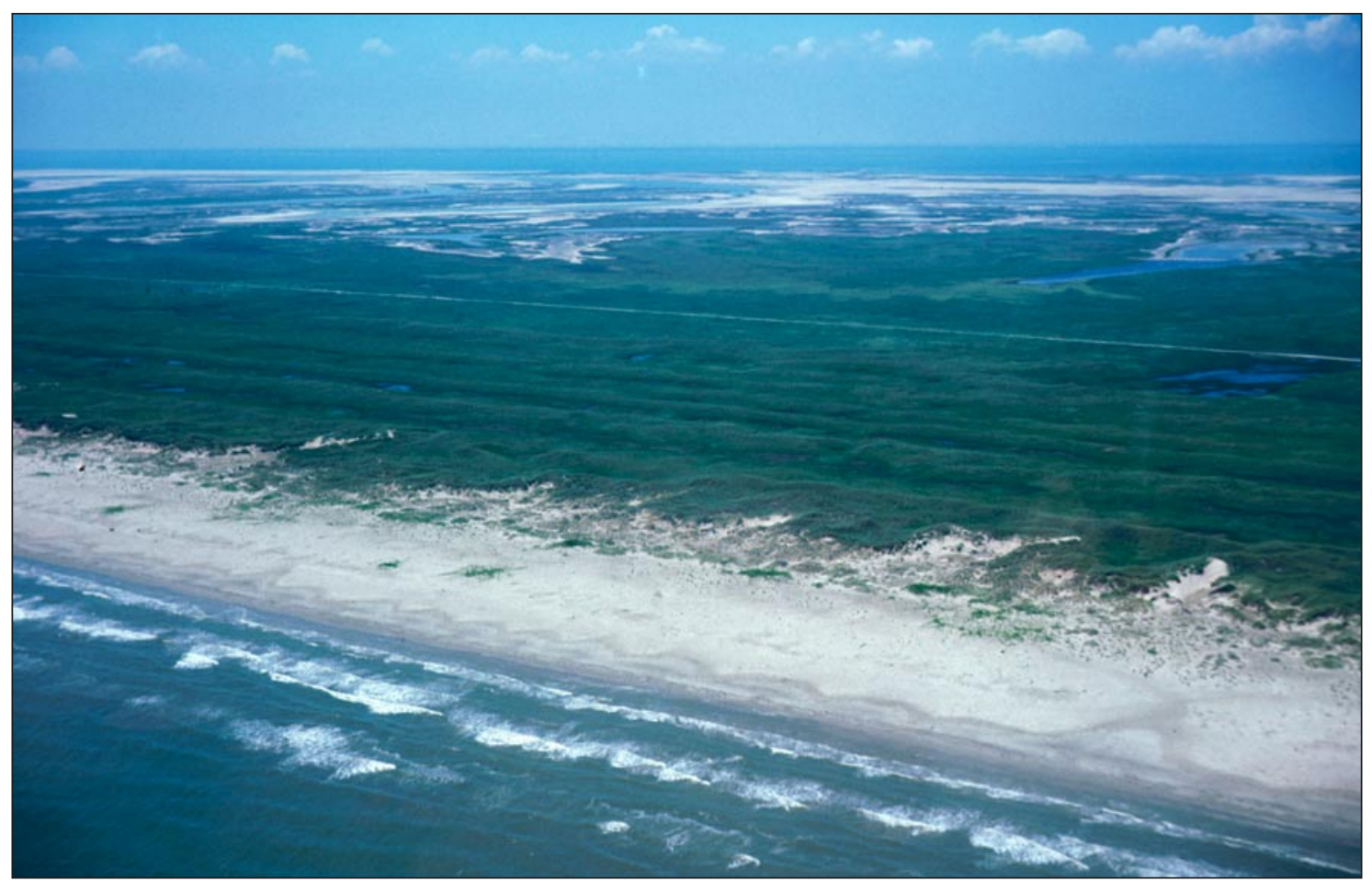

Figure 8. Long linear ridges and swales that characterize some Gulf Coast barrier islands, such as San Jose Island, Texas mark the former positions of the Gulf shoreline. These features record shoreline accretion at time scales of thousands of years.

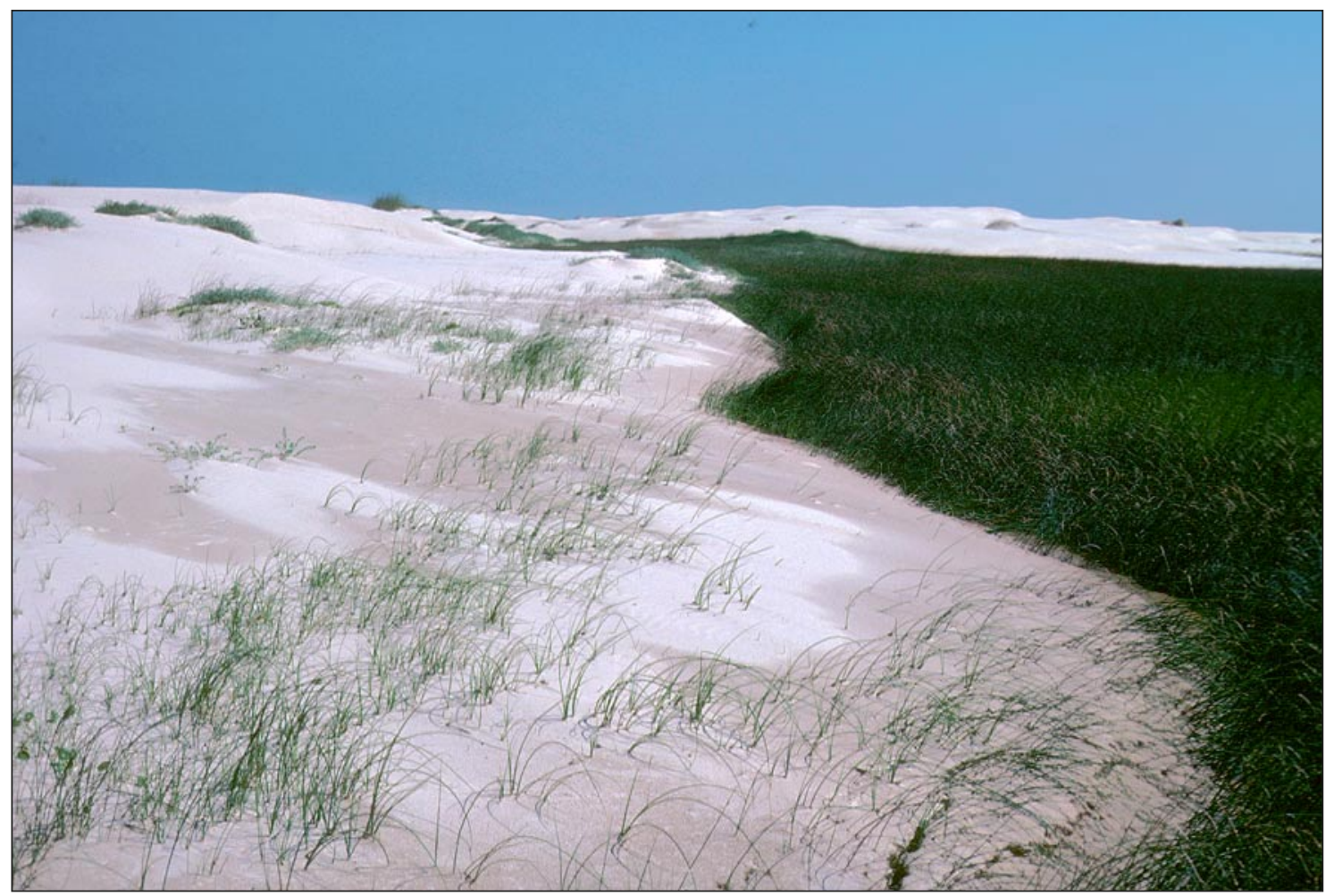

Figure 9. Fields of migrating sand dunes on North Padre Island, Texas may contribute to erosion by removing sand from the beach. Dunes are activated when the stabilizing vegetation is destroyed either as a result of natural causes (droughts, grass fires) or as a result of human activities (off-road vehicles, overgrazing, construction). 


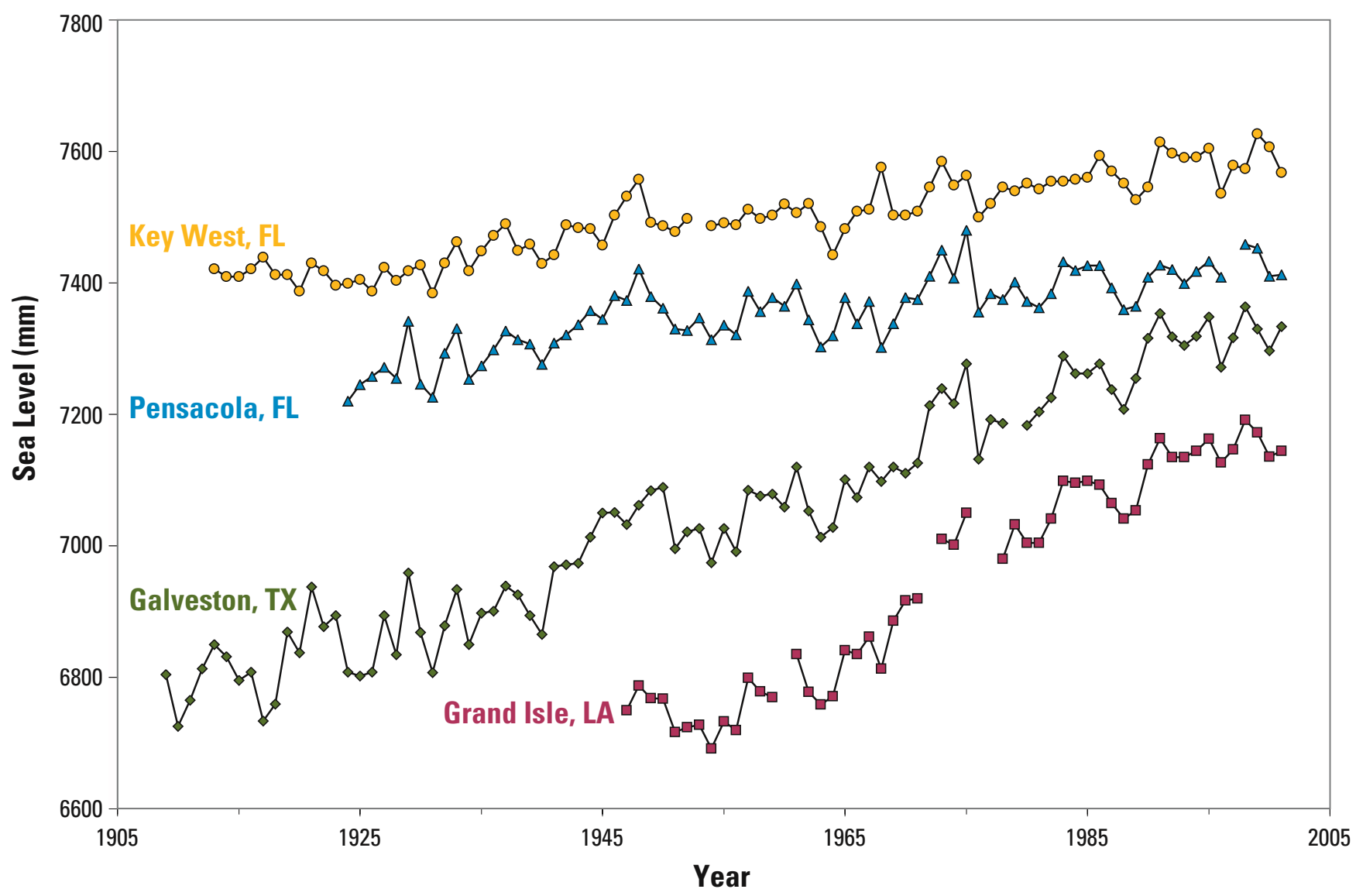

Figure 10. Long-term trends in average annual sea level at selected tide gauges in the Gulf of Mexico. Data are from the National Ocean Service.

at Galveston Island, Texas and Grand Isle, Louisiana show a relative rise in sea level of about 0.3 to $0.6 \mathrm{~m}$ during the 20th century (Lyles and others, 1988). This rate of rise is about 3 times faster than the global rise in sea level, which recently has averaged about $0.18 \mathrm{~m}$ per century (Gornitz and Lebedeff, 1987).

The difference between recorded rates of submergence along the Gulf Coast and the global rate of sea level rise is caused mostly by subsidence (Swanson and Thurlow, 1973). Releveling surveys show that the subsidence is related to regional tilting of the coastal plain; areas near and seaward of the shoreline are sinking while inland areas are being uplifted (Swanson and Thurlow, 1973, Holdahl and Morrison, 1974, and Jurkowski and others, 1984). Within the regional trend are areas where subsidence rates are high, such as the Houston-Galveston area (Fig. 11) and the Mississippi delta where accelerated sinking is attributed respectively to ground-water withdrawal (Gabrysch, 1984), and sediment compaction and oil and gas production (Roberts and others, 1994; Morton and others, 2002).

Fair-weather waves in the Gulf of Mexico are normally less than 0.6 m high (Bretschneider, 1954; U.S. Army Corps of Engineers, 1983). The largest waves and highest sustained wind speeds in the Gulf of Mexico accompany major hurricanes. They also are responsible for the most property damage and loss of lives. Hurricanes entering or originating in the Gulf normally follow a northward or westward path (Fig. 12). The preferred paths of the storms determine the likelihood that a storm will make landfall at a particular site. Using historical sites of hurricane landfall, the National Hurricane Center has shown that the areas at greatest risk are around Galveston, Texas, southeastern Louisiana, and the Mississippi/Alabama coast (Simpson and Lawrence, 1971). Because hurricanes seldom recurve and make landfall near St. Petersburg Florida, this part of the west Florida coast has the lowest probability of a storm in any year. However, because of the high density of development and population, this area has one of the highest potentials for a storm-related catastrophe.

Before crossing the northern Gulf Coast, the counterclockwise circulation of hurricane wind drives nearshore currents and large volumes of beach and shoreface sand alongshore. High tides, large waves, and strong currents that accompany the storms can leave semi-permanent marks on the barrier islands and beaches. For example, the erosional escarpment carved by Hurricane Elena in 1985 is still visible along the northern shore of St. George Sound, Florida. Storm channels that breached Dauphin Island, Alabama in the early 1900s and again in 1948 were reoccupied in 1979 when Hurricane Frederic completely washed over 


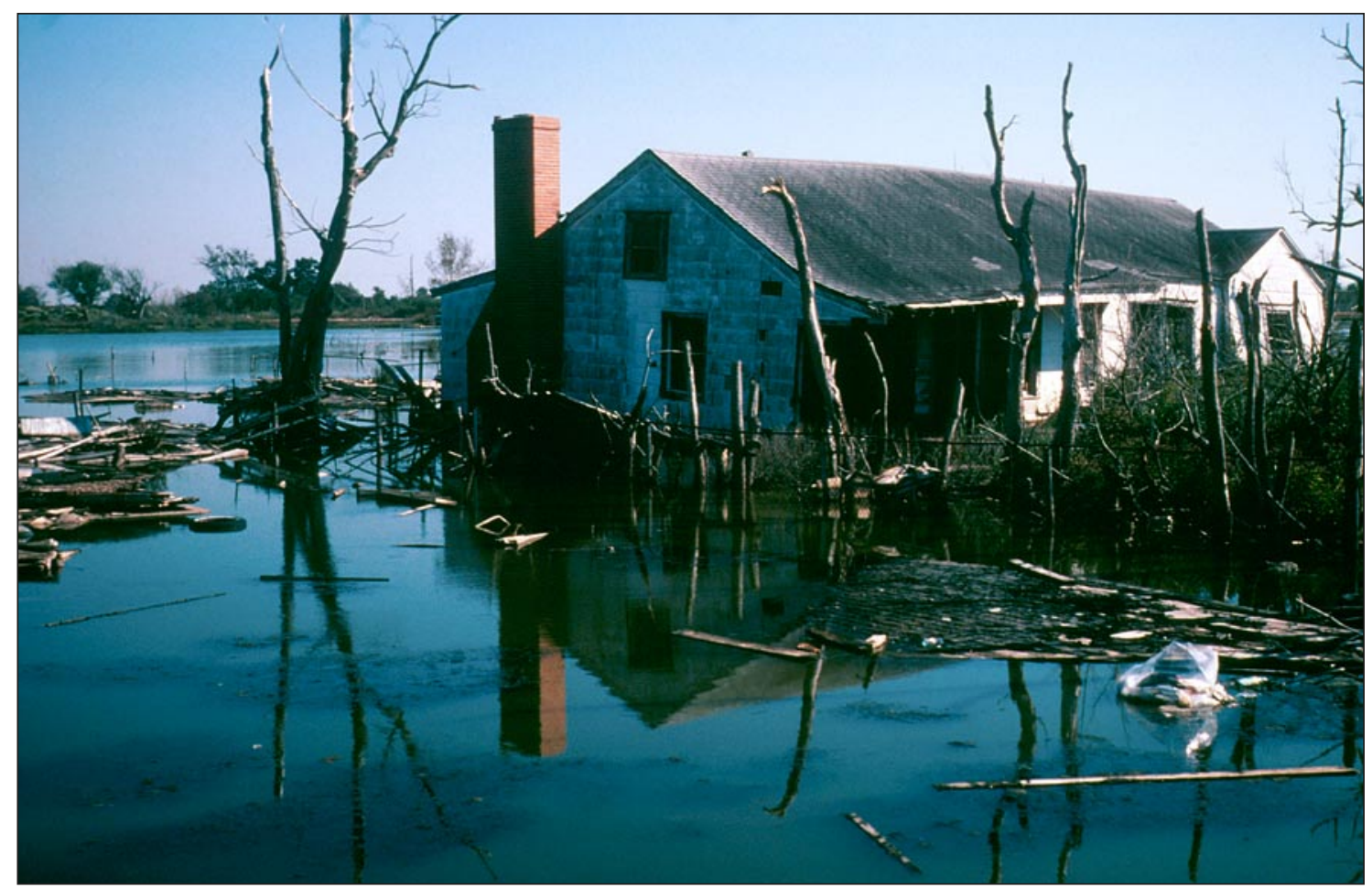

Figure 11. A coastal subdivision of nearly 200 homes near Houston, Texas was submerged as a result of subsidence induced by ground-water production.

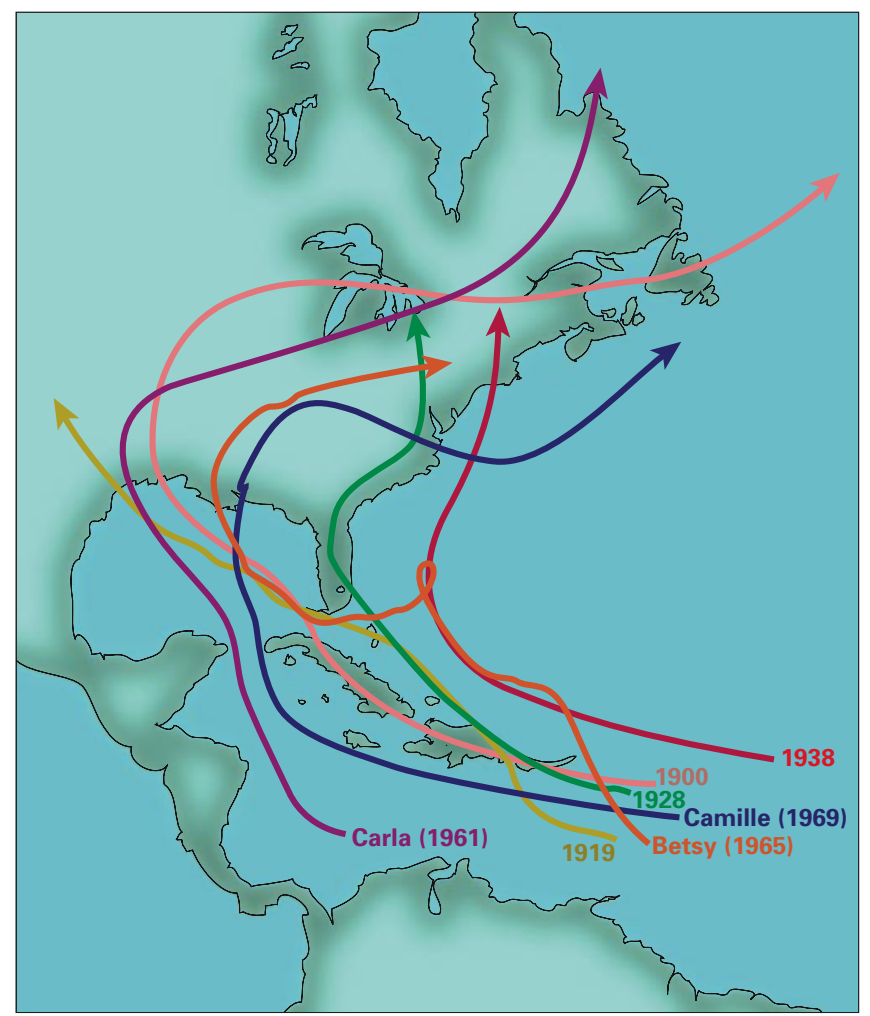

Figure 12. Tracks of some of the most deadly and destructive Atlantic and Gulf hurricanes in the 20th century. Data are from the National Hurricane Center. the island destroying the causeway that links the island to the mainland. During the next year (1980) Hurricane Allen reoccupied more than 60 washover channels through South Padre Island, Texas destroying, in several places, the main road that runs the length of the island. In Florida, even relatively weak storms have destroyed piers, seawalls, dune walkovers, swimming pools, roads, houses, motels, and other buildings because structures were poorly sited and the beach did not recover from storm erosion before the next storm arrived (Clark, 1986). The hard lessons of Hurricanes Camille, Frederic, and Eloise (Fig. 13) were not heeded by coastal residents of Mississippi, Alabama, and Florida who rebuilt in the same place after each of these major storms.

\section{Sand Sources}

Eroding mainland shores and the continental shelf are the primary sources of sand for maintaining the Gulf Coast barriers and beaches. Gulf Coast rivers generally do not contribute significantly to the present sand budget of Gulf Coast beaches. A few rivers, such as the Rio Grande and Brazos in Texas, add sand directly to the littoral system, but most of the rivers empty into estuaries and deposit their sediment loads far inland from the shoreline. The Mississippi River in Louisiana deposits its load of fine-grained sediments at the edge of the continental shelf in relatively deep water where it is unavailable to build beaches and barriers.

Natural reductions in sand supply during the past few thousand years were further aggravated by recent human 


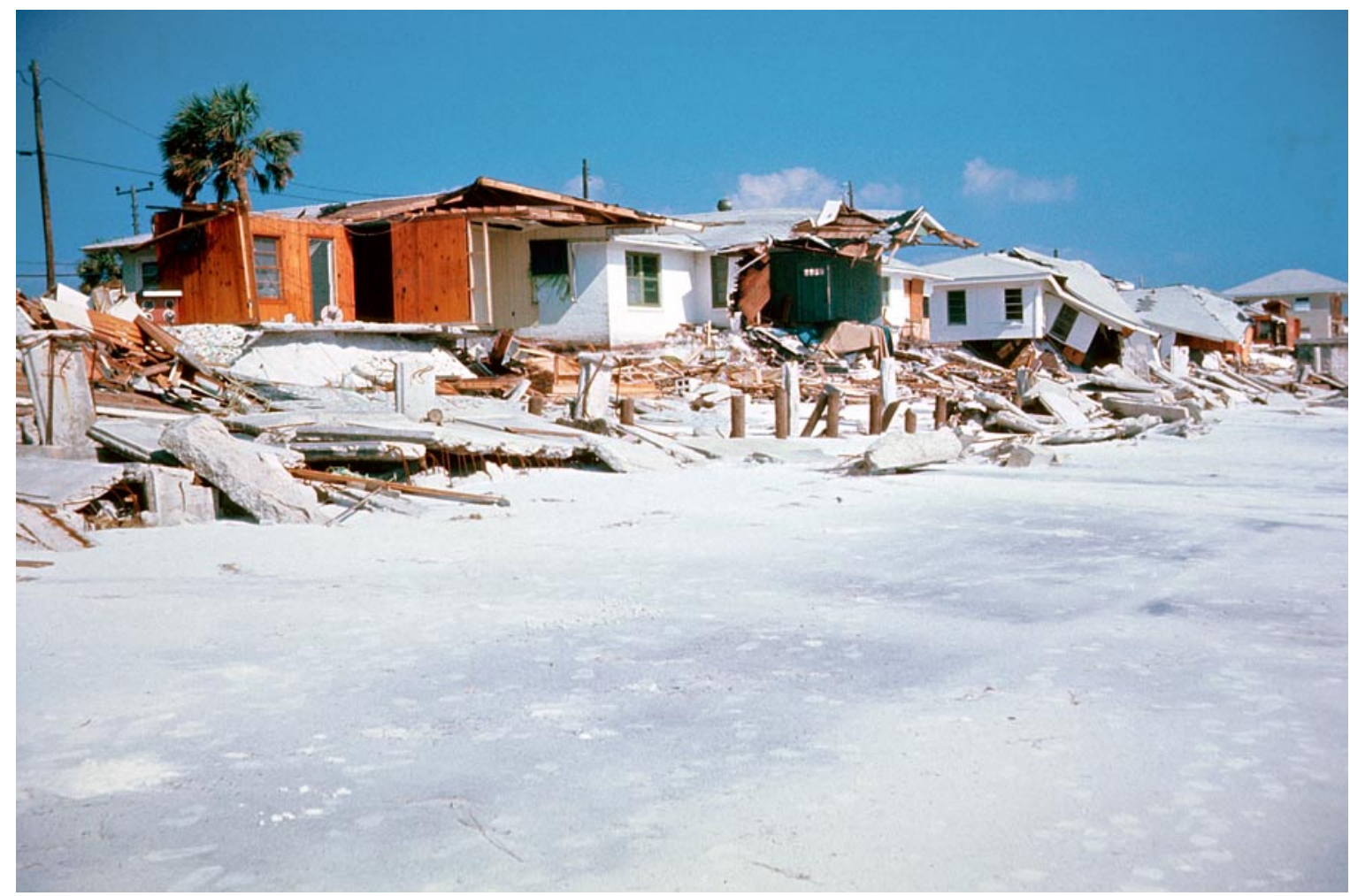

Figure 13. Property damage near Panama City, Florida caused by Hurricane Eloise in 1975. From Morton (1976).

activities such as damming rivers, dredging channels, and constructing jetties. Flood-control structures caused most rivers to lose their capacity to transport sediment, thus dramatically decreasing the amount of sediment delivered directly to the Gulf shoreline or the bayhead deltas. Even if some river-borne sediment reaches the Gulf shore, the jetties at inlets disrupt the longshore currents and compartmentalize the coast, preventing sediment exchange from one coastal segment to another. Before the littoral drift system was altered, sand was naturally bypassed around tidal inlets and shared between neighboring coastal segments. Now there are many coastal compartments isolated by long impermeable jetties or deep navigation channels like those maintained at the entrance to Tampa, Mobile, Galveston, and Corpus Christi Bays. This human interference with littoral drift has caused some formerly accreting or stable shores to begin eroding (Morton, 1979).

\section{GENERAL CHARACTERISTICS OF THE GULF SHORES BY STATE}

The southwest, west, and panhandle coasts of Florida offer a rich diversity of shoreline types, compositions, and degrees of economic development. This coastal region contains mangrove swamps, sandy barriers and mainland beaches, irregular drowned karst topography, and marshes. Barrier islands occupy much of the shore from Marcos Island to Anclote Key and from Destin to Perdido Key (Fig.
3). Exceptions are the topographically high sandy uplands that extend from Marco Island to Sanibel Island and from St. Joseph Peninsula to Destin. Barrier islands also fringe the Apalachicola Delta, but it forms a large promontory that abruptly changes the shoreline orientation. The delta also marks the northern limit of the low wave-energy coast, which coincides with the drowned karst topography that extends southward to Anclote Key (Price, 1953; Tanner, 1960). Marsh and upland hammocks cover the drowned limestone segment. It lacks well-developed surface drainage, and the tidal creeks are largely controlled by fracture patterns in the underlying limestone bedrock. Streams in this karst region do not transport any significant load of sediment suitable for building or maintaining beaches. Large linear oyster reefs grow in the Gulf of Mexico where brackish salinities are maintained by freshwater inflows from underground springs and surface streams such as the Crystal River in Florida. The few pocket beaches fronting marsh of the low wave-energy coast are composed mostly of broken shells derived from the oyster reefs and offshore shoals (Davis and others, 1985).

Alabama has the least amount of ocean shore of the Gulf Coast states. In terms of landforms, the Alabama coast is similar to that of Texas and Florida where sandy barrier islands (Dauphin Island, Morgan Peninsula, Perdido Key) are close to but separated from the mainland by lagoons. Other features in Alabama that are similar to the other coasts are the unfilled river valleys (Mobile Bay, Perdido Bay) that dominate the landscape. 
The Mississippi coast is composed of a chain of barrier islands separated by wide tidal inlets, mainland bluffs covered by dense pine forests, and small marshes crossed by tidal creeks and bayous. It is a unique coast in that it has two open shores, the one fronting the barrier islands and the mainland shore bordering Mississippi Sound. The barrier islands are low, narrow, and generally migrating to the west due to the westerly alongshore currents. Sand that maintains the Mississippi barriers is derived from the east or from the sandy platform underlying the barriers (Otvos, 1979). Although Mississippi barriers are low and the intervening tidal inlets are wide, they absorb most of the wave energy generated in the Gulf before it reaches the mainland. Exceptions are during large hurricanes, such as Camille (category 5 ), that completely overtop the barriers and directly impact the mainland shore. Hurricane channels periodically cut Mississippi coast barriers, such as in 1969 when Camille Cut bisected Ship Island.

The modern birdfoot delta and older delta lobes of the Mississippi River dominate the Louisiana coast. Because the delta is composed predominantly of mud, most beaches are only veneers of sand that are retreating over the delta plain. Barrier islands fringing the delta represent thin wedges of reworked sand that are also retreating landward at high rates. These low, relatively narrow barriers are frequently overwashed by storm surges that erode sand from the Gulf side and deposit it in adjacent bays and sounds, resulting in landward migration of the barriers (McBride and others, 1992). Chandeleur, Grand Gosier, Curlew, and Breton Islands make up an eastern arc of migrating barriers that outline the abandoned and foundering lobe of the St. Bernard subdelta. Eroding sandy beaches and short barriers typify the shore on the west flank of the birdfoot delta. These beaches extend westward to Grand Isle, which is a barrier attached to the abandoned Lafourche lobe of the delta. Narrow sandy beaches form the Caminada-Moreau headland shore of the Lafourche subdelta, whereas the Timbalier Islands and the Isles Dernieres are narrow, low migrating barriers that formed on an older, more rapidly subsiding part of the Lafourche subdelta. From the Isles Dernieres westward to Grand Chenier the Gulf shore consists of marshes and mud bars. The mud bars are supplied by westward flowing littoral currents and the Atchafalya River that empties into Atchafalya Bay. Western coastal Louisiana consists of high sandy beach ridges with intervening marsh swales that together make up a headland known as the chenier plain. Sandy beaches of the chenier plain extend from Grand Chenier into southeastern Texas.

The beaches and barriers of the Texas coast are arranged in an orderly pattern with respect to the Holocene river deltas (Brazos-Colorado and Rio Grande) and Pleistocene mainland shores (Morton, 1979). All these mainland shores, which are composed of muddy deltaic sediments, form moderately large promontories in the Gulf of Mexico. The promontories focus wave energy and have been eroding for the past few thousand years. The lack of abundant sand along the rapidly eroding mainland shores prevents the growth of sand dunes; consequently, the highest elevations along the mainland shores coincide with a narrow terrace of washover deposits composed of sand and shell. Between the mainland shores, littoral currents converged and deposited their sand load. The result was construction of the high-profile barriers (Bolivar Peninsula, Galveston Island, Matagorda Island, San Jose Island, Mustang Island, North and Central Padre Island) and their large foredunes. The low-profile transgressive barriers (Follets Island, Matagorda Peninsula, South Padre Island) formed on the flanks of the mainland shores as they continued to retreat. Shores of the Texas bays and lagoons are also varied in their composition and susceptibility to land loss.

\section{HISTORY OF INFRASTRUCTURE DEVELOPMENT}

Since their discovery by French and Spanish explorers, the Gulf Coast barriers and mainland shores have served as safe harbors that promoted early economic development related to shipping and other maritime activities. Barriers strategically located at the mouths of major bays were the sites of quarantine stations, supply docks, military installations, and trading posts. Early resort development of most Gulf Coast barriers was slowed because of their remoteness, and in some areas, such as Mississippi and Texas, there was a lack of fresh water and adequate building materials.

The west Florida coast experienced high-density development during the post World War II building boom, and many of the building practices and codes were not suitable for coastal construction. Many of these construction deficiencies were exposed shortly after development began, but some of the consequences are still being experienced. For example, beach houses built in the 1950s near Panama City, Florida were sited on the dunes using slab-on-grade foundations. This standard building practice is used extensively at inland sites and it did not present a problem at the coast until 1975 when Hurricane Eloise destroyed long seawalls, undermined the dunes, and caused many buildings to collapse (Fig. 13). In 1992, Hurricane Andrew and its impact in south Florida revealed again that adequate building codes and code enforcement are generally lacking.

The only community development of a Mississippi barrier was on the Isle of Caprice in the 1920s (Canis and others, 1985). This small ephemeral sand shoal was unstable and the resort development did not survive. Both the shoal and development declined in later years.

Because most of coastal Louisiana is extremely low and flooded frequently, economic development has been greatly limited and restricted to a few areas. Exceptions are local infrastructures that were built to support the widespread petroleum production activities. Grand Isle is the only barrier island in Louisiana that has roads and both residential and commercial development. The development 
began as recreational fishing camps and facilities that serviced the offshore petroleum industry. More recently, Grand Isle has been developed for permanent residents and as a destination for tourists. The coastal communities of Holly Beach and Peveto Beach are located in the chenier plain south of Cameron, Louisiana. These unplanned developments bordering the Gulf of Mexico consist of small beach houses that were constructed in the 1960s before the threat of beach erosion was well understood.

The Gulf Coast barriers have always had a strong military presence beginning with early construction of forts and continuing today with its Naval Stations and Air Force bases. In fact, fortifications and training facilities represent the earliest occupation of some Gulf Coast barrier islands. Construction of most of the forts was begun in the early to the mid 1800s. Many of the barriers were bombing ranges during World War II and some were used for target practice through the Vietnam War. None of the active military bases are currently threatened by coastal erosion because facilities near the water are armored by hard structures. Some of the training facilities have been closed or dismantled, but most of the land has remained in the public domain and is controlled by state or federal agencies and will not be developed for commercial purposes.

Some of the oldest landmarks, like lighthouses and forts, are especially vulnerable to erosion because these aids to navigation and military defense were built on the tips of barrier islands or on points of land that provided unobstructed visibility. These structures also provide a basis for determining long-term shoreline change. For example, the Cape San Blas, Florida lighthouse has been relocated six times because of continued erosion and shifting of the Cape (Tanner, 1975). The lighthouse at the entrance to Mobile Bay also stands as a testament to the shifting sands of time. This structure was built on Sand Island, but the island migrated westward more than $3 \mathrm{~km}$, leaving the lighthouse exposed to wave attack. The lighthouse is now surrounded by water and protected by a rock revetment that prevents it from being completely undermined and destroyed. The history of Fort Massachusetts on Ship Island, Mississippi involves another story of island migration. When it was built in 1856, the Fort was centrally located on the island about $120 \mathrm{~m}$ from Mississippi Sound, the Gulf of Mexico, and the western end of the island. More than 140 years later, the Sound side of the island has eroded, flooding the foundation of the Fort, which is more than $1100 \mathrm{~m}$ from the western end of the island (Boone, 1973). Although continued migration of Ship Island to the west is not likely because a ship channel at the western end of the island is maintained by dredging, there is a continuing threat of Sound side erosion.

Most of the Gulf beaches front private property. The longest publicly owned beaches belong to the National Park Service. The NPS is responsible for managing Padre Island National Seashore in Texas and Gulf Islands National Seashore, which includes all of the barriers in Mississippi (including parts of Cat Island), and part of Santa Rosa Island and Perdido Key in Florida. In addition to these federal holdings, the Gulf States have many state and local parks that account for a significant percentage of the non-private Gulf-front property.

\section{SHORELINE CHANGE AND COASTAL LAND LOSS}

In this section shoreline changes are presented with an emphasis on shoreline erosion, because it is an important natural coastal hazard along many Gulf of Mexico beaches. Table 7 summarizes both long-term and short-term rates of shoreline change as averages of all the changes, including both erosion and accretion, and as averages of only the erosion values and only the accretion values. Distinguishing between erosion and accretion provides more quantitative detail to the results.

The summary discussion includes references to shoreline erosion and to the broader issue of coastal land loss in order to provide a more complete perspective of coastal change. In the Gulf Coast states coastal land loss is occurring primarily because of episodic high wave energy, natural changes in the coastal system, and as a consequence of human activities (Clark, 1990; Morton and Paine, 1990; Penland and others, 1990; Smith, 1990). Additional information about coastal land loss is available in a USGS Open File Report at http://pubs.usgs.gov/of/2003/of03-3377.

\section{West Florida}

Land losses for west Florida are primarily associated with erosion of sandy beaches and barrier islands, especially around inlets (Clark, 1991) where swift tidal currents easily remove the loose sand that forms the ends of the barriers. Land loss in the bays and lagoons of west Florida is minor because these water bodies are generally small or are already protected by erosion control structures such as bulkheads (Doyle and others, 1984).

Compared to shoreline erosion in some other Gulf Coast states, the average long-term erosion rate of $-0.8 \pm 0.9$ $\mathrm{m} / \mathrm{yr}$ for west Florida (Table 7a) is low, primarily because wave energy is low. Even though erosion rates are generally low, more than $50 \%$ of the shoreline is experiencing both long-term and short-term erosion. The highest rates of erosion in west Florida are typically located near tidal inlets. Long-term and short-term trends and rates of shoreline change are similar where there has been little or no alteration of the sediment supply or littoral system (see Dog Island, St. George Island, and St. Joseph Peninsula). Conversely, trends and rates of change have shifted from longterm erosion to short-term stability or accretion where beach nourishment is common (see Longboat Key, Anna Maria Island, Sand Key, and Clearwater, Panama City Beach, and Perdido Key). A shift from long-term relative stability to 


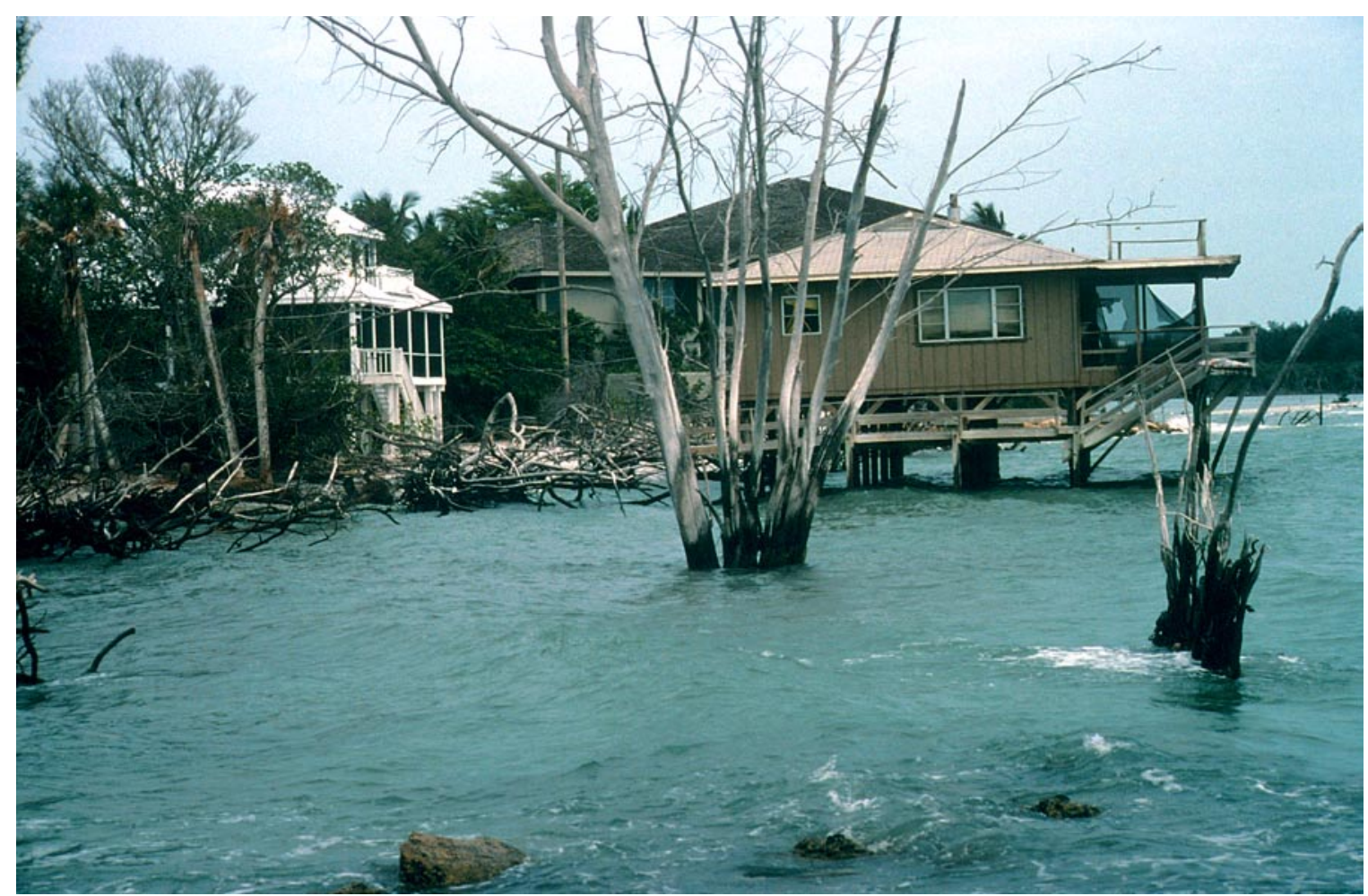

Figure 14. Erosion of the Gulf shore eventually destroyed this beach house at Captiva Island, Florida.

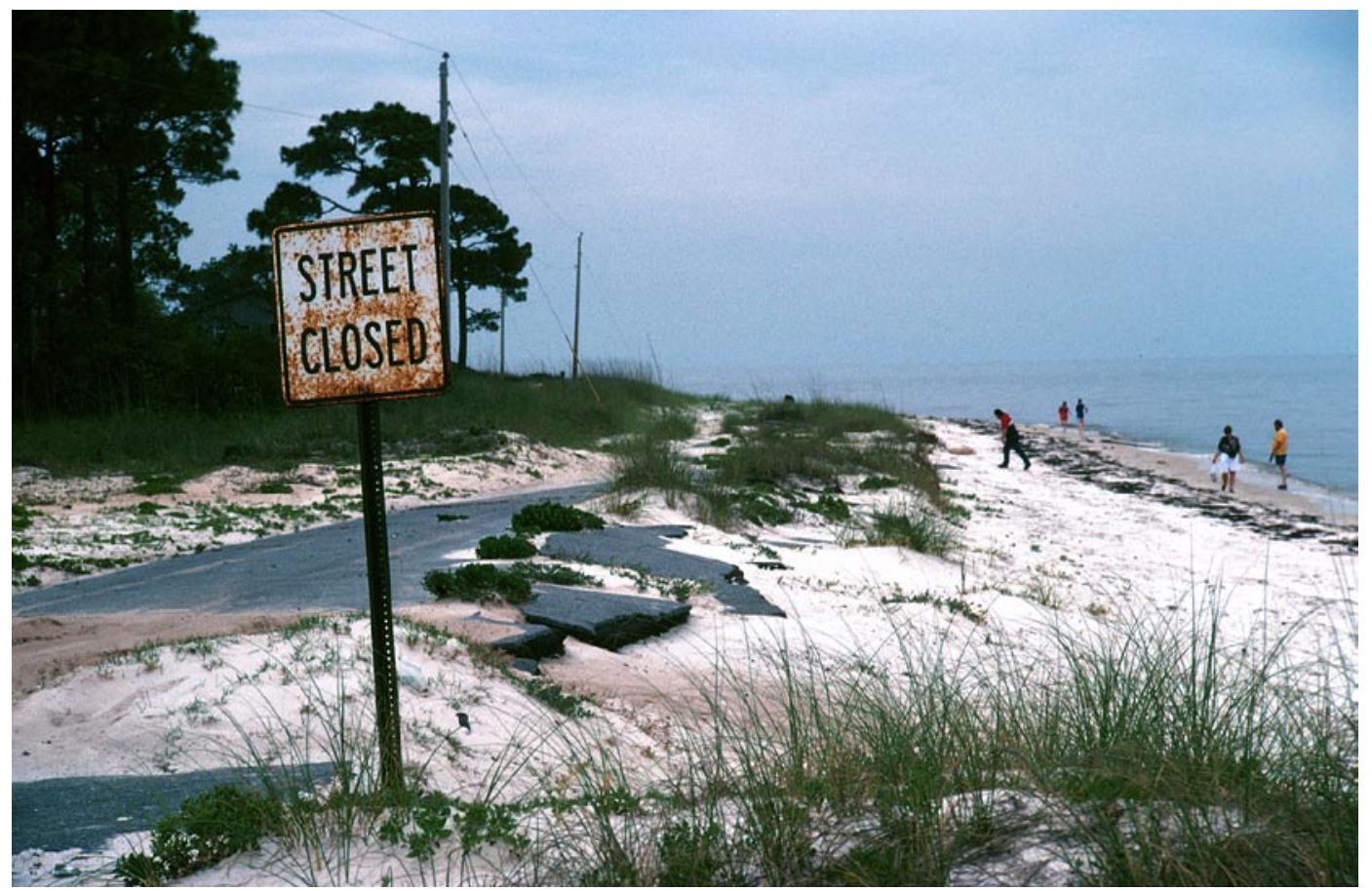

Figure 15. Even where wave energy is normally low, episodic erosion during storms is capable of destroying roads and eliminating the beach. This example of erosion along the low energy coast is from Lighthouse Point, Florida. 


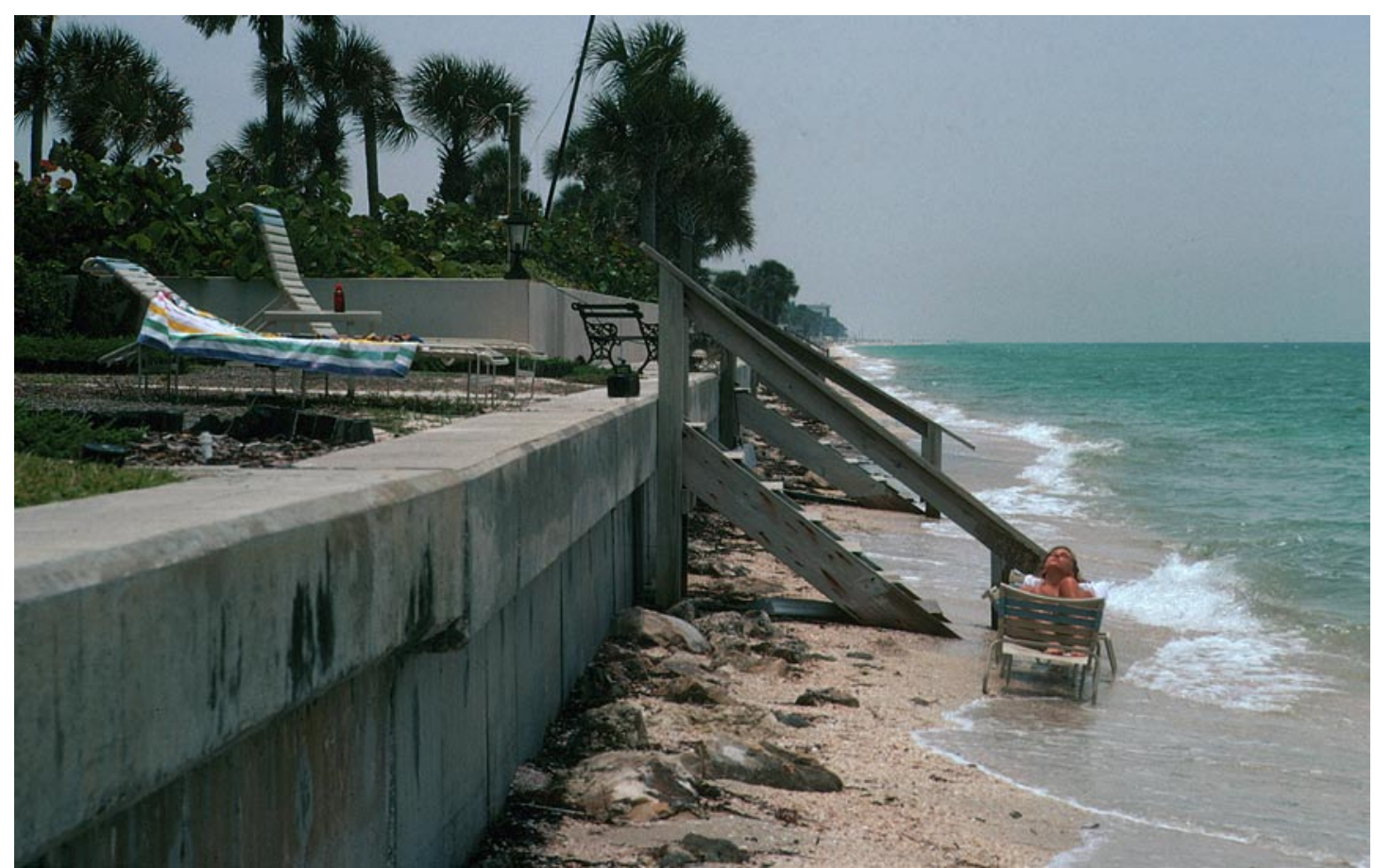

Figure 16. This narrow eroding beach in front of a seawall near Clearwater, Florida was used for recreation before beach nourishment.

short-term erosion occurred on Santa Rosa Island, probably as a result of beach erosion and overwash deposition associated with Hurricane Opal in October 1995.

Slow but chronic erosion along the west coast of Florida eventually results in narrowing of the State's valuable recreational beaches (Figs. 14-16), and many highly developed beaches retain no dunes to protect buildings from large storm waves and flooding. Lighthouse Point, south of Tallahassee, presents a good example. Situated in the low energy sector of the coast, past storms have still destroyed park facilities and some roads (Fig. 15) that are now protected by rock revetments. In places where beach erosion is chronic, these structures have replaced the beaches (Fig. 16) except where artificially nourished (Fig. 17).

\section{Alabama}

In Alabama, coastal land loss is caused primarily by beach and bluff erosion. Other mechanisms for loss, such as submergence, appear to be minor. Slope failure accounts for much of the land loss along the east and west shores of Mobile Bay (Smith, 1990). Although bay shorelines were not analyzed in this study, Smith (1990) reported that high bluffs on the eastern side of the bay are retreating at rates of -1 to $-1.5 \mathrm{~m} / \mathrm{yr}$. Along the Alabama Gulf shoreline, the western half of Dauphin Island is experiencing short-term erosion of as much as $-4.7 \mathrm{~m} / \mathrm{yr}$. An exception is the westernmost $3 \mathrm{~km}$ of the island, which is accreting as the island lengthens to the west. Stumps of former pine trees exposed on the beach at the Dauphin Island Public Beach are evidence of long-term beach erosion. Just east of the park is a large, active dune complex that is migrating into the pine forest and burying the trees. Although the reason for this dune migration is unclear, it is likely that this dune sand would reduce beach erosion to the west if it were available to the littoral system. Elsewhere along the Alabama Gulf shore, Morgan Peninsula and Perdido Key are relatively stable owing to a sufficient supply of sand by longshore transport to the west and local beach nourishment (Fig. 18).

\section{Mississippi}

Long-term rates of land loss for Mississippi mainland shores are relatively low. Extensive armoring and periodic beach nourishment around Mississippi Sound (Fig. 19) have greatly slowed land losses along these shores (Canis and others, 1985). However, the barrier island shores are eroding rapidly. Long-term rates show that $80 \%$ of the shoreline has experienced erosion at an average rate of $-3.1 \pm 1.8$ $\mathrm{m} / \mathrm{yr}$ (Table 7a). Short-term erosion is even more rapid with over $60 \%$ of the shoreline eroding at an average rate of $-5.8 \mathrm{~m} / \mathrm{yr}$ (Table $7 \mathrm{~b}$ ). Erosion is most pronounced at the eastern (updrift) ends of the barriers where short-term rates of erosion average $-8.3 \mathrm{~m} / \mathrm{yr}$ and long-term rates average $-4.6 \pm 1.6 \mathrm{~m} / \mathrm{yr}$. The systematic pattern of updrift erosion and downdrift deposition that transfers sand from east to west and promotes westward migration has also reduced the island areas by about one third since the 1850s (Byrnes and others, 1991).

The most dramatic example of coastal erosion and land loss in Mississippi was the formation and destruction of the Isle of Caprice. This relatively small sand shoal formed 


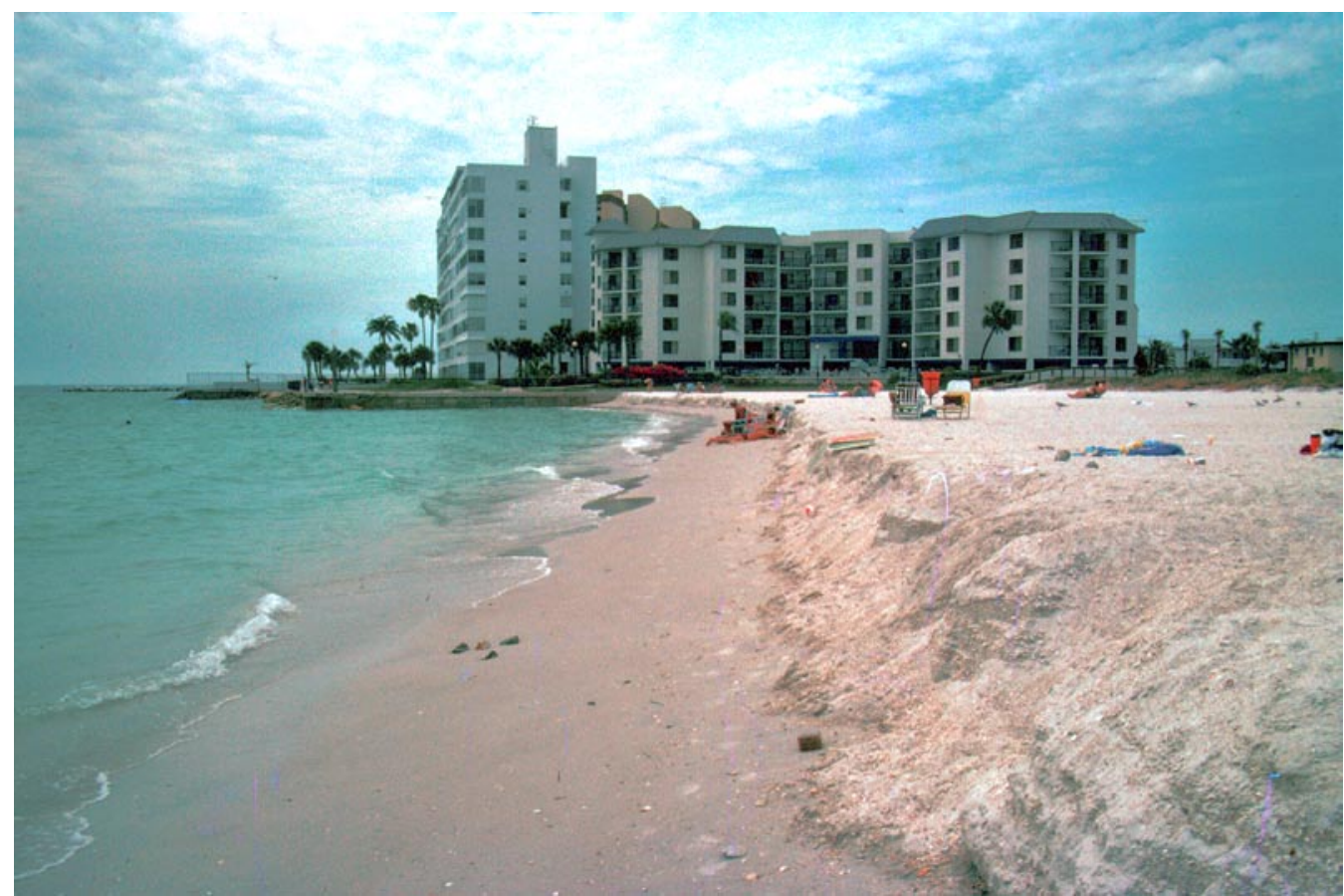

Figure 17. Many nourished beaches along the west Florida coast, such as this one on Sand Key, have steep erosional escarpments early in the history of the project.

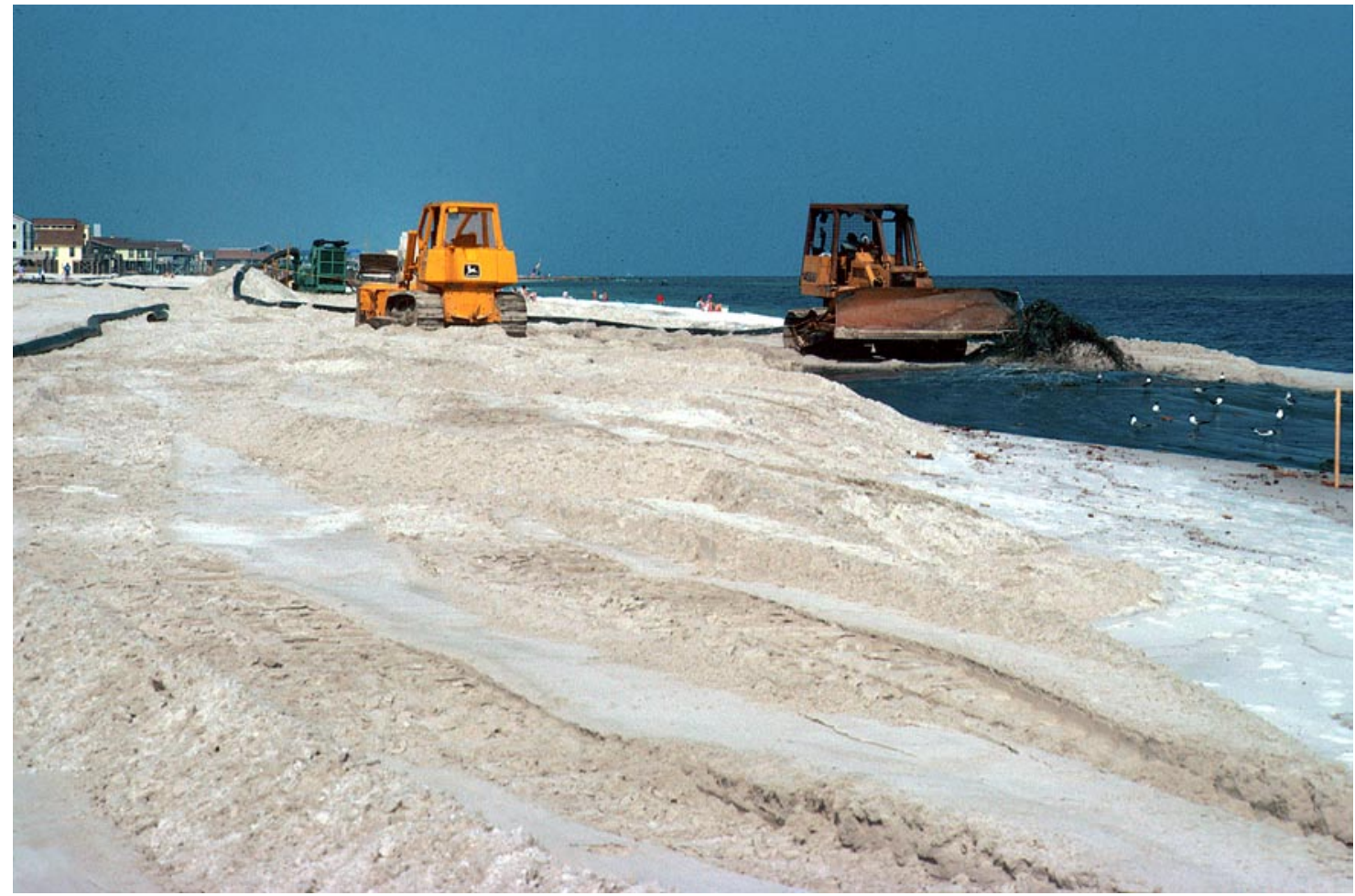

Figure 18. A beach nourishment project near Gulf Shores, Alabama. Accelerated erosion in front of the beach houses was attributed to construction of an artificial channel and jetties. 


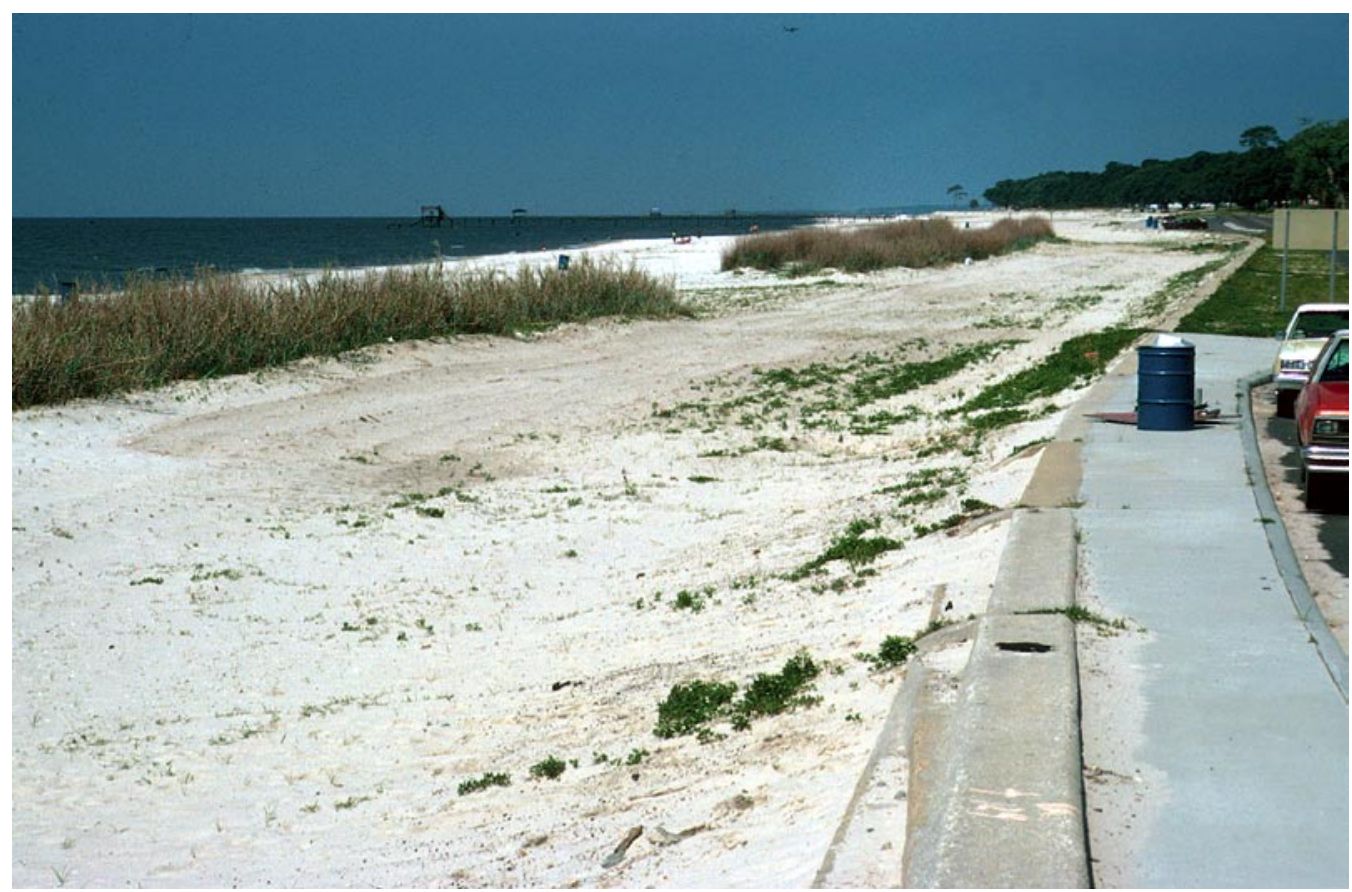

Figure 19. The seawall along U.S. 90 at Biloxi, Mississippi extends for nearly 27 miles. This reinforced concrete structure provides protection from minor storms and high water but it was unable to prevent massive destruction and death caused by Hurricane Camille in 1969.

in Mississippi Sound between Horn and Ship Islands as a result of barrier migration and changes in current patterns within the adjacent tidal inlet. The Isle of Caprice emerged between 1917 and 1924 when sand deposited between two channels caused several small sand shoals to coalesce (Rucker and Snowden, 1988). In the mid 1920s, during the Prohibition Era, it was developed into an entertainment center with cabanas, a gambling casino, restaurant, artesian potable water supply, electric power plant, and a ferry landing (Rucker and Snowden, 1988). By 1932, all of these assets had been completely destroyed by the Gulf waters and there was no evidence of the Isle of Caprice.

\section{Louisiana}

The highest rates of laterally continuous shoreline retreat and land loss in the Gulf of Mexico are found in coastal Louisiana. While land loss associated with shoreline change along the Gulf shore and around the margins of large coastal bays is severe, loss of the interior wetlands is also extensive due to submergence and destruction of the Mississippi River delta plain (Penland and others, 1990). Subsidence and coastal erosion are functions of both natural and human induced processes. The natural delta cycle begins with construction of a delta lobe. Eventually that lobe is abandoned as the river system relocates to another area. Following abandonment, the delta lobe subsides as sediments compact and the area becomes submerged because no additional sediment is available to offset the subsidence. Sediment supply to the delta also has been artificially reduced by controlling the Mississippi River and preventing it from flowing into the Atchafalya Basin. Recent studies have also suggested that hydrocarbon production has been partly responsible for accelerated subsidence and wetland loss (Morton and others, 2002).

About $90 \%$ of the Louisiana Gulf shoreline is experiencing erosion, which increased from an average of $-8.2 \pm$ $4.4 \mathrm{~m} / \mathrm{yr}$ in the long-term to an average of $-12.0 \mathrm{~m} / \mathrm{yr}$ in the short term (Tables $7 a$ and b). Short sections of the shoreline are accreting as a result of lateral island migration. The highest rates of Gulf shoreline erosion in Louisiana coincide with subsiding marshes and migrating barrier islands such as the Chandeleur Islands, Caminada-Moreau headland, and the Isles Dernieres. The frequent breaching of the Chandeleur Islands makes shoreline delineation difficult at many locations and prevents calculation of accurate rates of change along some barrier segments. The change from long-term erosion to short-term accretion on the west end of Grand Isle is related to frequent beach nourishment efforts. Elsewhere, beach nourishment along the Caminada headland and the Isles Dernieres, and a rock revetment along East Timbalier Island have not substantially reduced the rates of erosion at those locations.

\section{Texas}

In Texas, a combination of erosion and submergence contribute to land loss, which is concentrated along the Gulf shoreline and along bay marshes and bluffs (Morton and Paine, 1990). Wetland losses, which constitute about $75 \%$ 


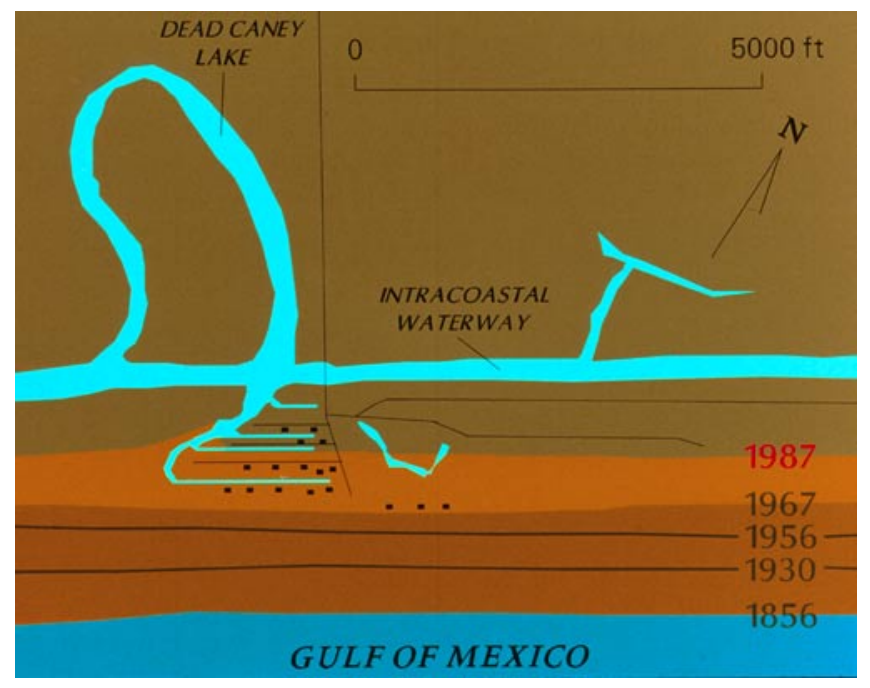

Figure 20. Long-term Gulf shoreline erosion at Sargent Beach, Texas.

of the total land losses, have dramatically accelerated both directly in response to human activities or indirectly as a result of modifications to the coastal system. Rates of land loss around bays are highest near the heads of the largest bays where long wave fetch and high bluff elevations produce unstable conditions. Wave erosion at the base of bluffs causes slumping and bluff retreat at rates of -0.6 to $-1.2 \mathrm{~m} / \mathrm{yr}$ (Morton and Paine, 1990) that threatens houses, power lines, and pipelines.

Erosion of Gulf beaches in Texas is concentrated between Sabine Pass and High Island, downdrift (southwest) of the Galveston Island seawall, near Sargent Beach and Matagorda Peninsula, and along South Padre Island. The most stable or accreting beaches in Texas are on southwestern Bolivar Peninsula, Matagorda Island, San Jose Island, and central Padre Island.

Long-term erosion at an average rate of $-1.8 \pm 1.3 \mathrm{~m} / \mathrm{yr}$ characterizes $64 \%$ of the Texas Gulf shoreline (Table 7a). Although only $48 \%$ of the shoreline experienced short-term erosion, the average short-term erosion rate of $-2.6 \mathrm{~m} / \mathrm{yr}$ is higher than the long-term rate, indicating accelerated erosion in some areas. Sargent Beach (Fig. 20) is a good example of accelerated erosion. Since the mid-1800s, Sargent Beach has retreated almost $700 \mathrm{~m}$ at an average rate of $-4.4 \pm 2.2 \mathrm{~m} / \mathrm{yr}$. That rate has increased to $-6.4 \mathrm{~m} / \mathrm{yr}$ since the 1970s. Here the beach is steep, narrow, and composed of many clam and oyster shells that normally grow in the bays but not in the open Gulf. The absence of dunes and presence of a low overwash terrace that forms the backbeach are clear indicators of the rapid erosion and frequent storm waves that are responsible for the rapid land loss. Sargent Beach is far from sand sources and engineering projects and yet there is an unmistakable connection between updrift activities and the accelerated erosion. In 1929, the mouth of the Brazos River was relocated so that the entrance to Freeport Harbor would not shoal when the river flooded. After the river diversion, a delta formed at the river mouth and trapped the sand that normally would have flowed toward Sargent Beach.

\section{HUMAN RESPONSES TO COASTAL EROSION AND LAND LOSS}

Each Gulf Coast state uses a different combination of technical and regulatory responses to combat beach erosion and to mitigate land loss. The technical responses include hard structures, beach nourishment, sand bypassing at inlets, and retreat (Table 9). Many developed bay shores exhibit a patchwork of relatively low-cost structures such as wooden and metal bulkheads, concrete seawalls, revetments, and small groins. Common bay shoreline structures are rubble revetments composed of various materials including large rocks, broken masses of concrete, rubber tires, household appliances, and trash. These low-cost structures typically become ineffective in less than 20 years because the structures deteriorate and are unable to withstand the repeated forces of storm waves. Bulkheads or seawalls are used to protect portions of nearly all of the Gulf shore communities. These structures have little effect on beach stability where sand supply is plentiful, but on eroding beaches they can accelerate beach loss by reducing beach width and preventing the growth of dunes (Morton, 1988).

The following statements illustrate the types of community and individual responses to shoreline erosion in the Gulf of Mexico. They provide typical examples rather than a comprehensive review of shoreline protection projects within each state. The examples also reveal some of the unintended consequences of shoreline development and subsequent modification.

Hard structures such as seawalls, rock revetments, bulkheads, and groins are common along the west coast of

Table 9. Technical responses to erosion and land loss in the Gulf Coast region.

\begin{tabular}{ll}
$\begin{array}{l}\text { 1. Protect Shore from Wave and Current Energy } \\
\text { Structural }\end{array}$ & \begin{tabular}{l} 
Non-structural \\
\hline Seawalls
\end{tabular} \\
$\begin{array}{l}\text { Bulkheads } \\
\text { Breakwaters }\end{array}$ \\
Revetments & Horizontal Relocation \\
2. Maintain or Increase Sediment Supply \\
Structural & Non-structural \\
\hline Groins River Diversion & \\
Perched Beaches & Beach Replenishment \\
& Sand Bypassing \\
& Beach Scraping \\
& Dune Restoration \\
& Submerged Berms \\
& Artificial Seaweed
\end{tabular}

3. Nullify Sea-Level Rise

Structural

Seawalls

Dikes and Levees 


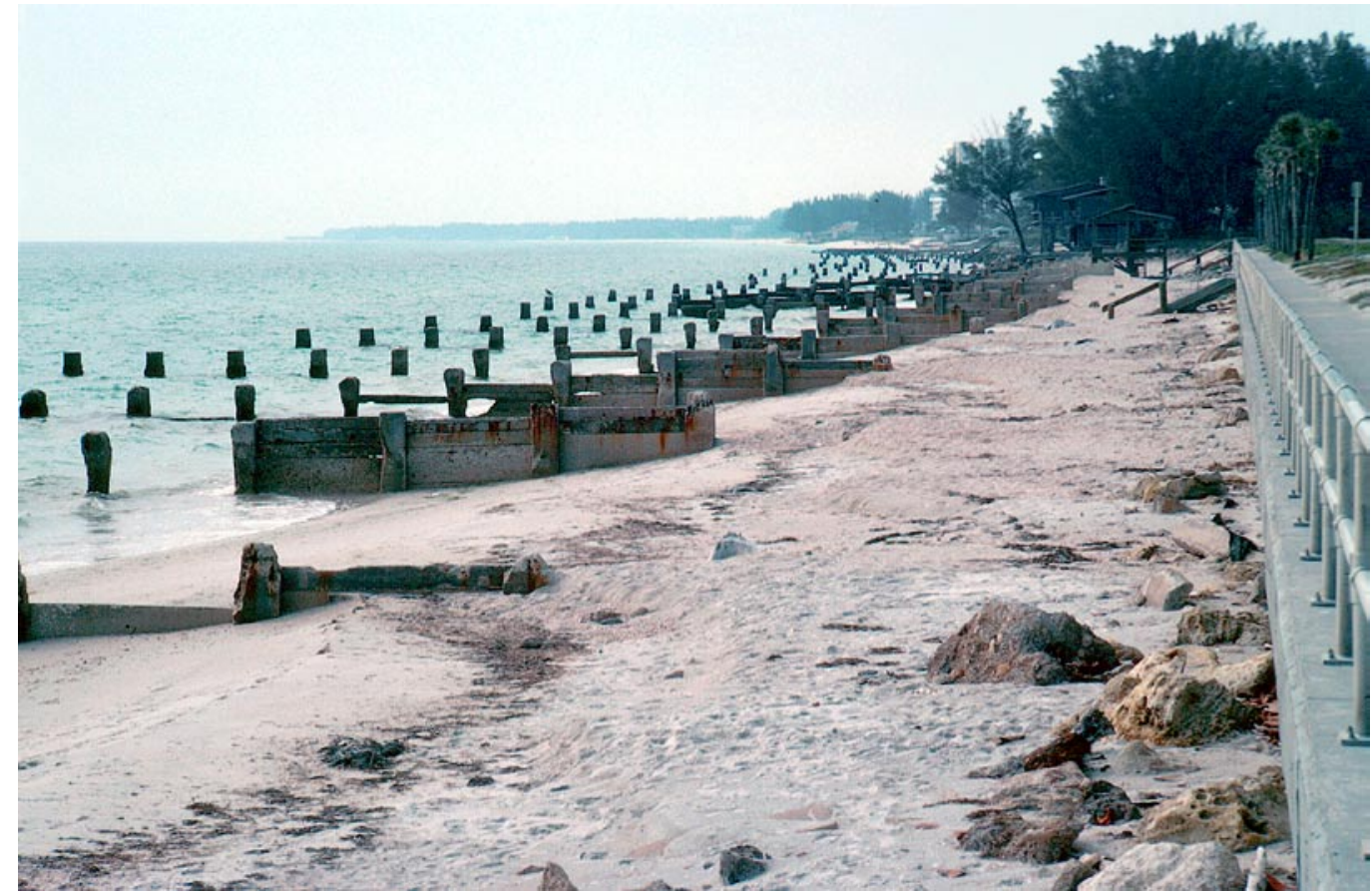

Figure 21. Multiple structures including a seawall, riprap, and failed groin field have been unable to stop erosion at Longboat Key, Florida. Later these structures were removed and the beach was nourished.

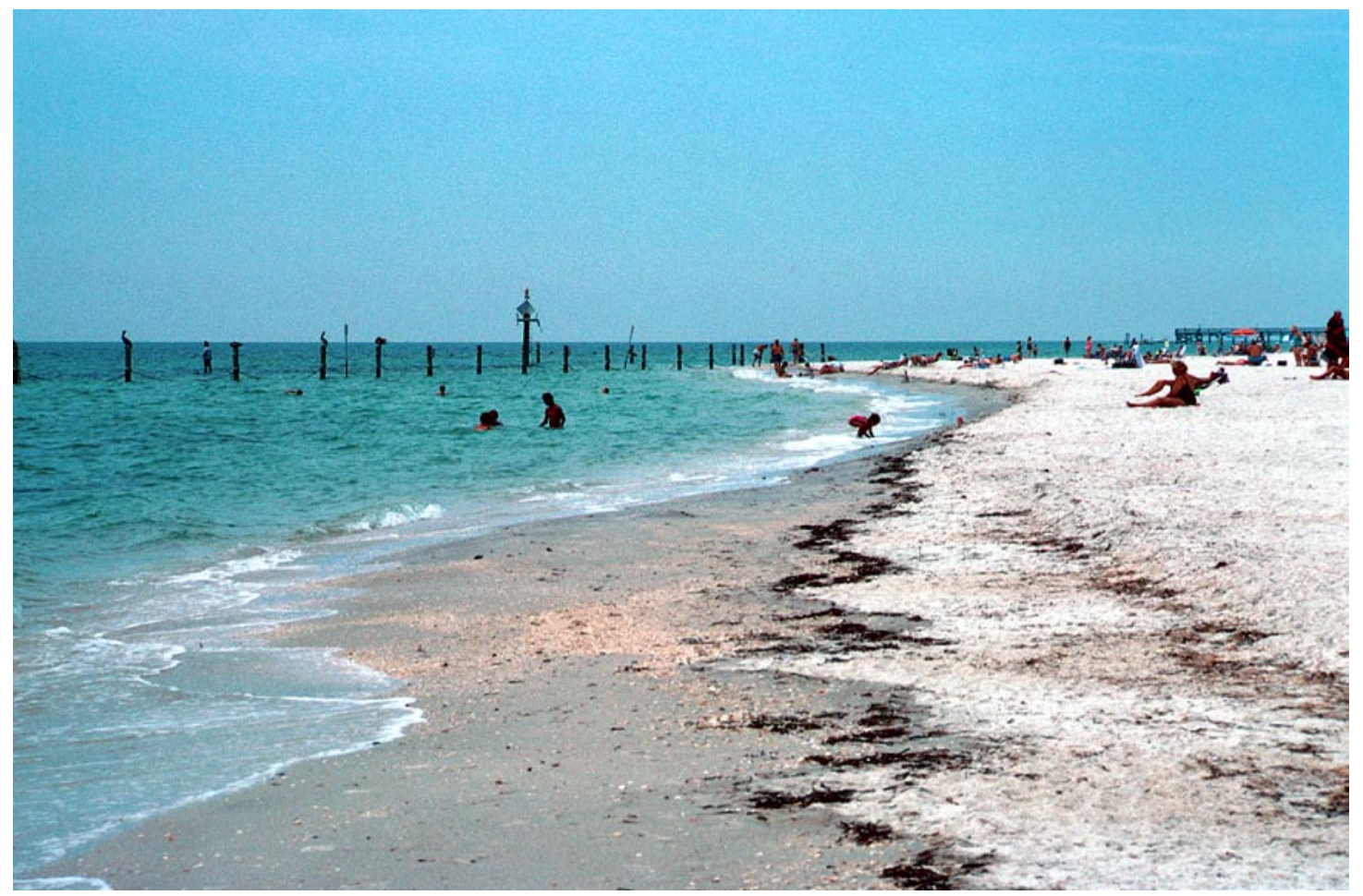

Figure 22. The breakwater at Redington Shores, Florida has protected the beach fill but has aggravated erosion of adjacent sand beaches. 
Florida (Figs. 16 and 21) where high-density development has existed for more than 40 years. The submerged breakwater at Redington Shores, Florida (Fig. 22) is an example of unexpected environmental and social costs resulting from construction of a hard structure. When it was built in 1985, this rubble mound breakwater and beach fill were designed to create a recreation beach and to protect a seawall without causing additional downdrift erosion (Dean and Pope, 1987). The breakwater was built $90 \mathrm{~m}$ offshore in about $2.5 \mathrm{~m}$ of water and is about $80 \mathrm{~m}$ long. About 46,000 $\mathrm{m}^{3}$ of fill material was dredged from a nearby tidal inlet and stockpiled for beach fill, but after Hurricane Elena only half of the dredged material remained for beach nourishment (Dean and Pope, 1987). After the beach fill was added, the nourished beach responded to the lowered wave energy by building toward the breakwater. This created a safety hazard since swimmers were attracted to the breakwater because it was in shallow water and close to the beach. The submerged rock mounds have protected the artificial beach and seawall, but they increased downdrift beach erosion and created unusually deep scour holes around the mounds that contributed to at least five deaths by drowning.

In both Alabama and Florida, bulkheads are built to protect the foundations of hotels and condominiums on the Gulf, but the beach is wide enough that these structures currently are not directly interfering with beach processes. The most common hard structures used to mitigate beach erosion in Alabama are rock revetments and riprap. At the eastern end of Dauphin Island, the beach adjacent to Fort Gaines continues to erode even though several attempts have been made to stabilize it with groins and large blocks of riprap (Fig. 23).

The mainland shore of Mississippi is almost completely armored by low bulkheads, revetments, and seawalls in combination with other structures such as groins and riprap. The 40-km long stepped seawall (Fig. 19) extending from Bay St. Louis to Biloxi covers the entire length of Harrison County. A beach is maintained along this relatively low-energy shore by periodic pumping of sand from Mississippi Sound. Some of the seawall was built along Mississippi Sound after the 1915 hurricane to protect the upland homes from being destroyed as the Pleistocene bluff retreated. In 1951, about 7 million $\mathrm{m}^{3}$ of sand dredged from the Sound was pumped up creating an artificial beach to protect the seawall and to provide recreational areas. Sand fences and grass plantings have been used along this nourished beach to encourage the development of sand dunes and to reduce the sand blowing across U.S. 90 (Fig. 19).

The rapidly retreating beaches of Louisiana were largely unaltered by hard structures until recently, but the high rates of wetland loss and concern for the future of the delta plain resources and petroleum industry infrastructure have led to the construction of several shoreline stabilization projects. Riprap revetments were constructed along the Caminada-Moreau headland. Rock revetments were also built to try to stabilize East Timbalier Island, but the subsidence and erosion were so severe that the rip rap structure was stranded in the Gulf of Mexico as the barrier continued to retreat landward. Six segmented breakwaters were constructed along the Isles Dernieres for a demonstration project and the construction of others along the island have

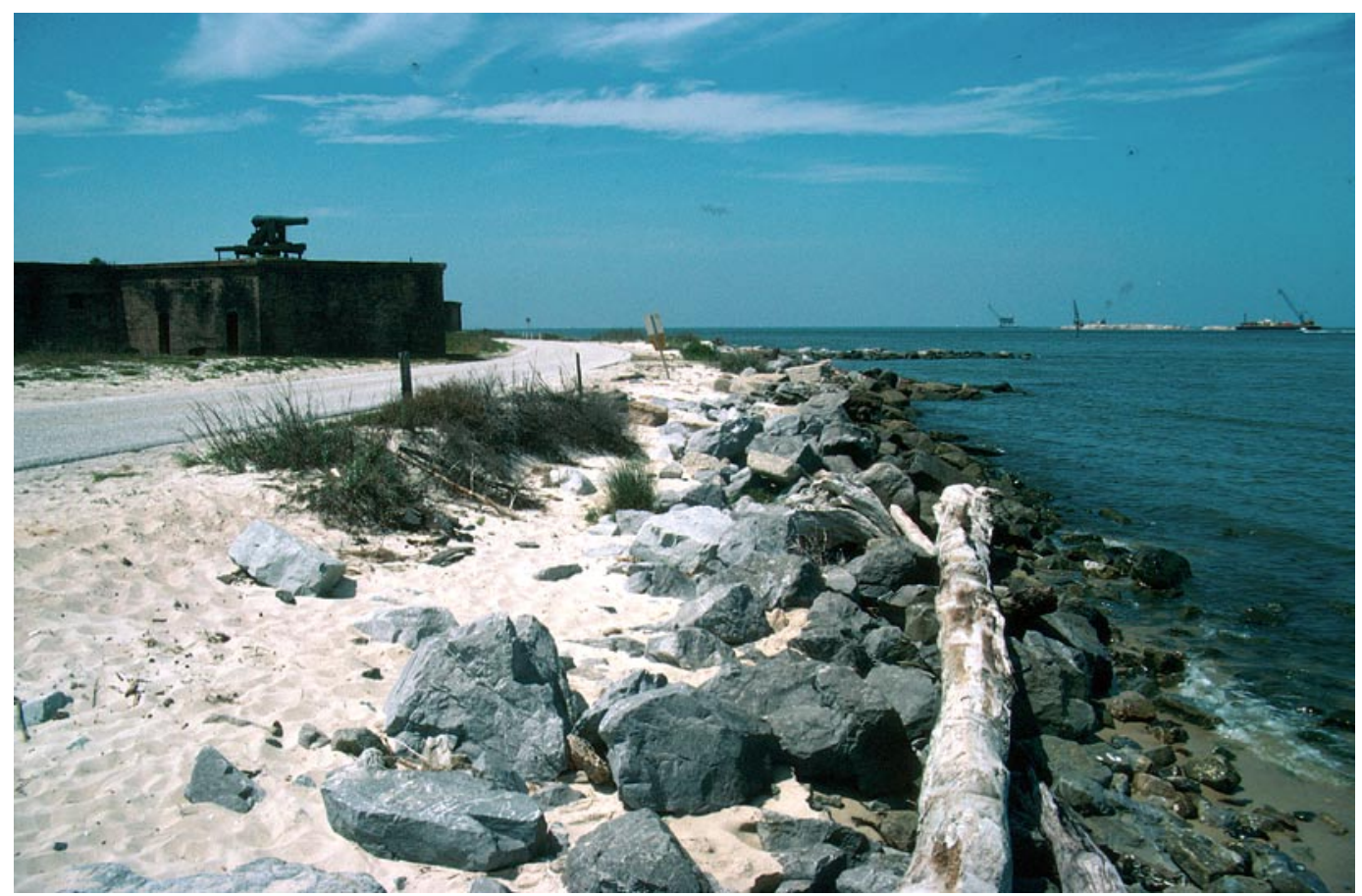

Figure 23. Rock revetments and groins have been used to control beach erosion at Fort Gaines on the east end of Dauphin Island, Alabama. 


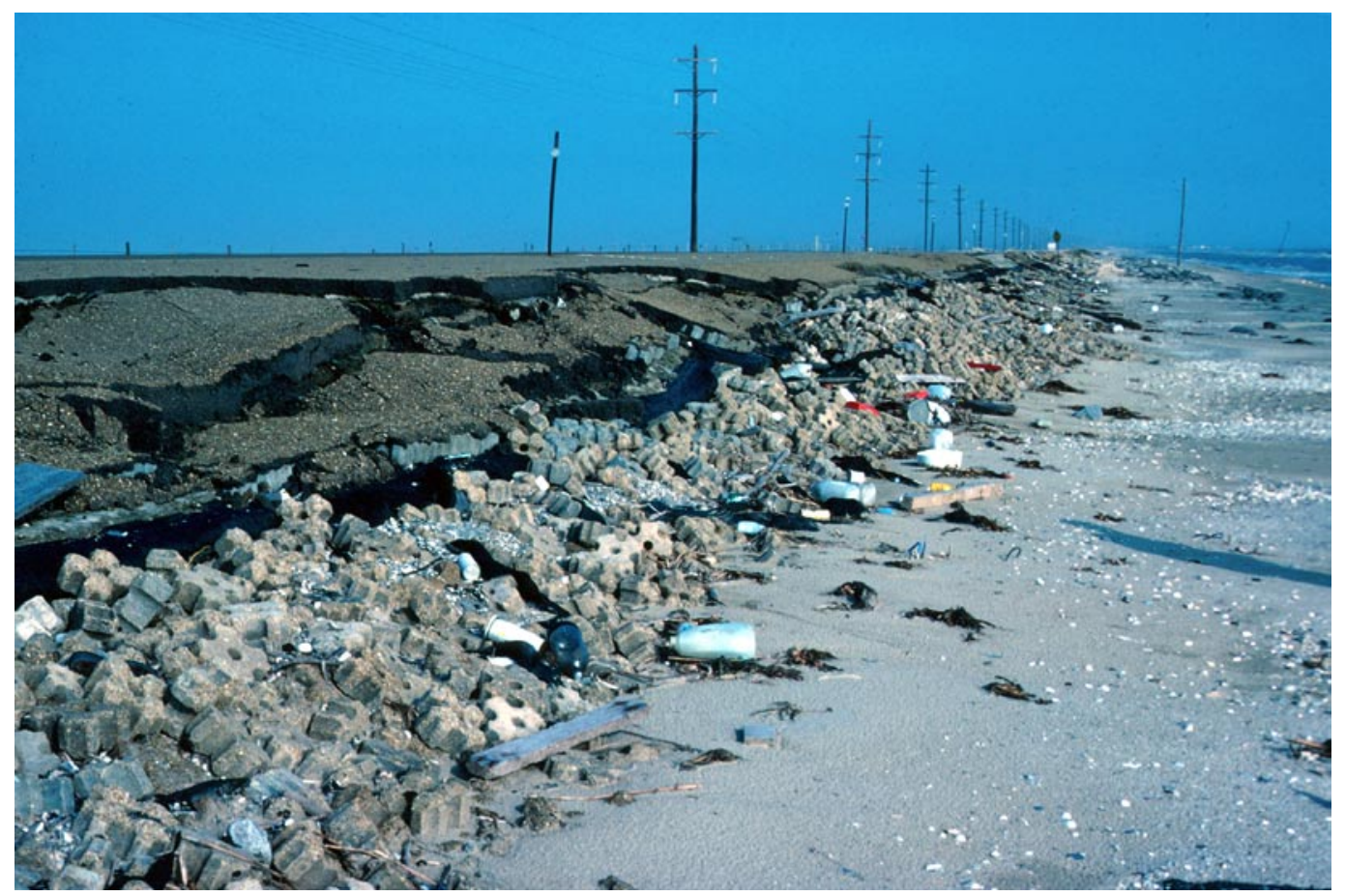

Figure 24. Storm waves in the Gulf of Mexico destroyed the interlocking block revetment constructed to protect Louisiana State Highway 82 near Peveto Beach (Fig. 3). The revetment structure was replaced with 85 segmented breakwaters between Constance Beach and Holly Beach (Fig. 3).

been proposed. Perhaps the longest breakwater project in the U.S. is the $12 \mathrm{~km}$ stretch of 85 segmented breakwaters between Holly Beach and Constance Beach of the chenier plain. The breakwaters were built to replace a failed revetment (Fig. 24) intended to protect Louisiana Highway 82 from storm damage.

Little of the Texas Gulf shoreline is stabilized by hard structures. Long seawalls have been constructed on Galveston, North Padre, and South Padre Islands, and these seawalls have caused some additional erosion of downdrift beaches (Morton, 1988). The most famous shoreline protection structure in Texas is the Galveston seawall, which stretches for more than $16 \mathrm{~km}$. The seawall was built in response to the enormous death and destruction caused by the 1900 hurricane. Construction first began in 1902 and continued sporadically until 1961 when the last section was completed. The crest of the wall was built $5 \mathrm{~m}$ above sea level to protect the city and residents from flooding by large storms. This high elevation required raising much of the city by jacking up the buildings on pilings and pumping sand beneath them. The seawall accelerated erosion in front of the wall and as the beach narrowed, the unprotected beach downdrift of the end of the seawall began to erode more rapidly. The ramp at the end of the wall is clear evidence of the erosion (Fig. 25). The ramp once served as the beach access road; now it is barricaded to prevent unsuspecting visitors from driving into the Gulf of Mexico. Because of the depleted recreational beach in front of the seawall, the
City of Galveston spent about $\$ 6$ million in 1995 to restore the sand beach and to reduce erosion.

Rarely are coastal engineering structures removed for any reason and they are usually either left to deteriorate, or less commonly, are maintained indefinitely. Exceptions to this general statement include the removal of the jetties in Alabama, a failed seawall on South Padre Island, Texas, and a failed groin field on Longboat Key, Florida (Fig. 21).

Beach nourishment (Figs. 17 and 18) is becoming a more popular alternative to structural erosion control in the Gulf of Mexico. Florida has spent the most money to nourish beaches and has the greatest number of projects, whereas Texas has the fewest nourished beaches. Trembanis and Pilkey (1998) reviewed beach nourishment data for the Gulf of Mexico through 1989 and reported that more than $80 \%$ of the projects were implemented to restore beaches of the west Florida coast, mainly between Clearwater and St. Petersburg. Sand has been trucked and hydraulically emplaced to nourish beaches and to reconstruct dunes at several sites in Texas including Bolivar Peninsula, Galveston Island, and Sargent Beach. These small, low-volume projects have provided only temporary relief. The largest beach nourishment projects in Texas were in front of the Galveston seawall and at the south end of South Padre Island.

One of the most successful beach nourishment projects in the Gulf (Fig. 19) has been along the mainland shore near Biloxi, Mississippi (Dixon and Pilkey, 1991). The beach fill has lasted an average of 15 to 20 years because it is partially 


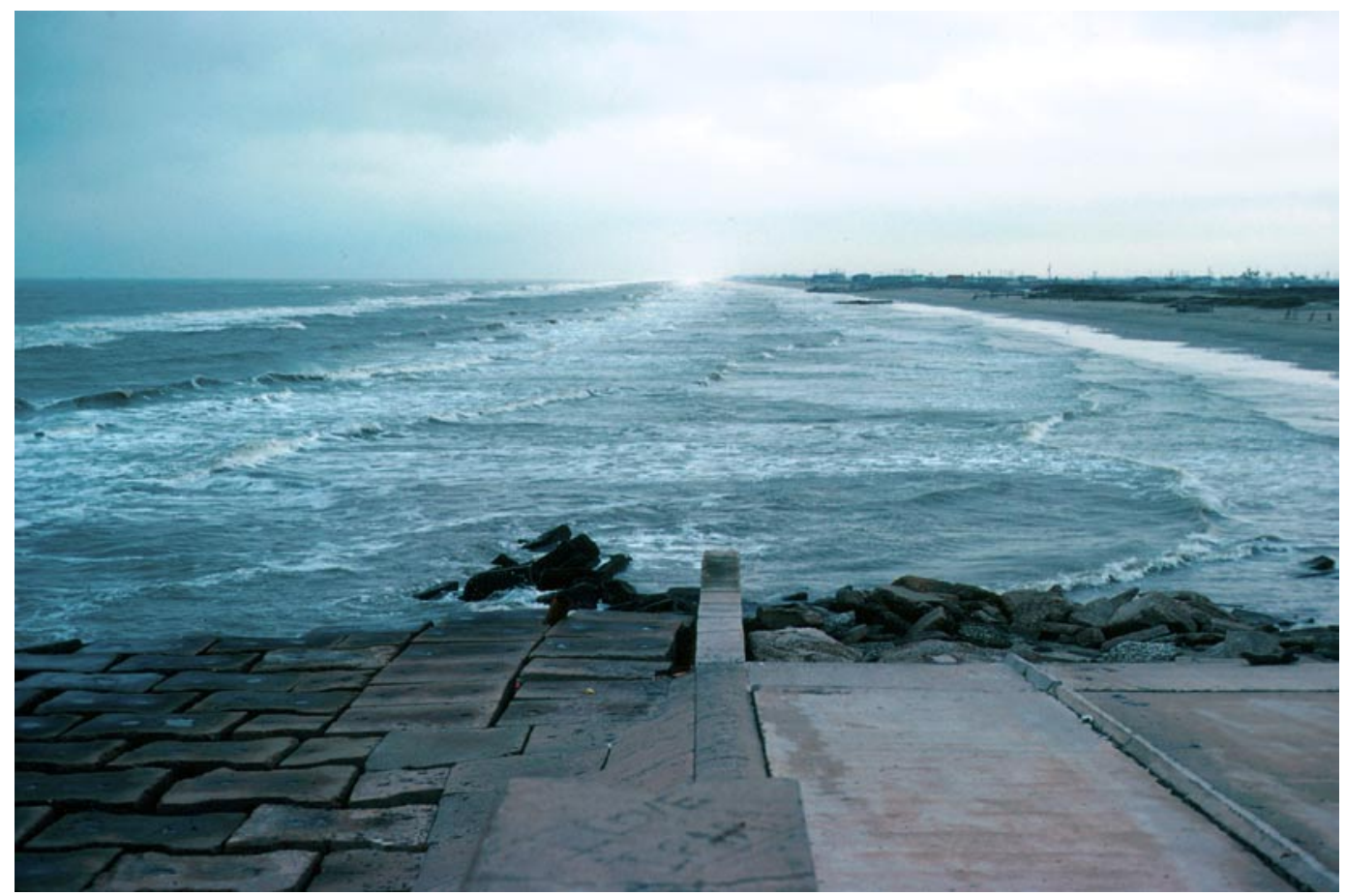

Figure 25. West end of the seawall at Galveston, Texas. The concrete ramp (right foreground) was the road leading to the beach in the mid 1960s. Since then the beach has eroded more than $150 \mathrm{~m}$.

protected by the barrier islands. Another durable nourished beach is at Captiva Island, Florida where fill is obtained from maintenance dredging of a nearby inlet. In general, nourished beaches last longer in the Gulf of Mexico than on either the Atlantic or Pacific shores because of the lower wave energy. Even though beach nourishment is a favored method of controlling beach erosion, it can lead to some unfavorable results, such as steep scarps (Fig. 17) and shelly or rocky beach material. A specific example of undesirable consequences of beach nourishment is the Egmont Key, Florida project that derived its fill from maintenance dredging of a nearby tidal inlet (Egmont Channel). The beach fill material was composed mostly of broken shell, which is less suitable than sand for beach durability and recreational comfort.

Sand bypassing is another engineering response to beach erosion at inlets where jetties are constructed to help maintain the inlet for boat traffic. At Perdido Key and Mexico Beach, Florida, small fixed bypassing plants have been constructed to transfer sand from the updrift side to the downdrift side of the inlet. Although these bypassing operations may reduce erosion at the inlets, they are unable to transfer the sand as efficiently as the natural unimpeded waves and currents. Therefore, sand bypassing does not entirely compensate for the erosion caused by the channel dredging and jetty construction.

Submerged berms (Table 9) are non-structural solutions to beach erosion near tidal inlets. They are constructed of sediment dredged from navigation channels and are currently being promoted as a solution to two problems, disposal of dredged spoil and mitigation of beach erosion. The dredged material is deposited under water in a low mound parallel to the beach and in relatively shallow water. The berm acts as a submerged breakwater causing large waves to break offshore, thus reducing storm beach erosion. If the berms are oriented properly and built in shallow water, the waves may transfer some of the sand onshore and add to the forebeach. In the Gulf of Mexico, the Corps of Engineers has constructed submerged berms to reduce erosion and storm damage of Dauphin Island, Alabama and South Padre Island, Texas. These projects are not as efficient in controlling beach erosion as direct placement of the dredged material on the beach, but they are also less costly than beach nourishment.

Deliberate relocation of buildings is not a common response to beach erosion and attendant coastal land loss in the Gulf Coast region. Nevertheless, there are several examples of voluntary relocation. Relocation of the visitor's center at Padre Island National Seashore (Fig. 26A and B) is a classic example of what happens when conventional wisdom is ignored at the coast. Optimistic planners projected that many visitors would come to Padre Island National Seashore each year. In response, a large visitor's center was built that included bathhouses, observation decks, offices, a restaurant, and a nature display describing the processes and ecology of the barrier island. Park officials, ignoring the possible consequences of building too close to the water, constructed the large concrete pile-supported building on the beach so that beach users would not be inconvenienced. Furthermore, the tall sand dunes that formed the highest barrier island elevations were destroyed to construct a parking lot and to provide access to the facilities. After about 20 years 

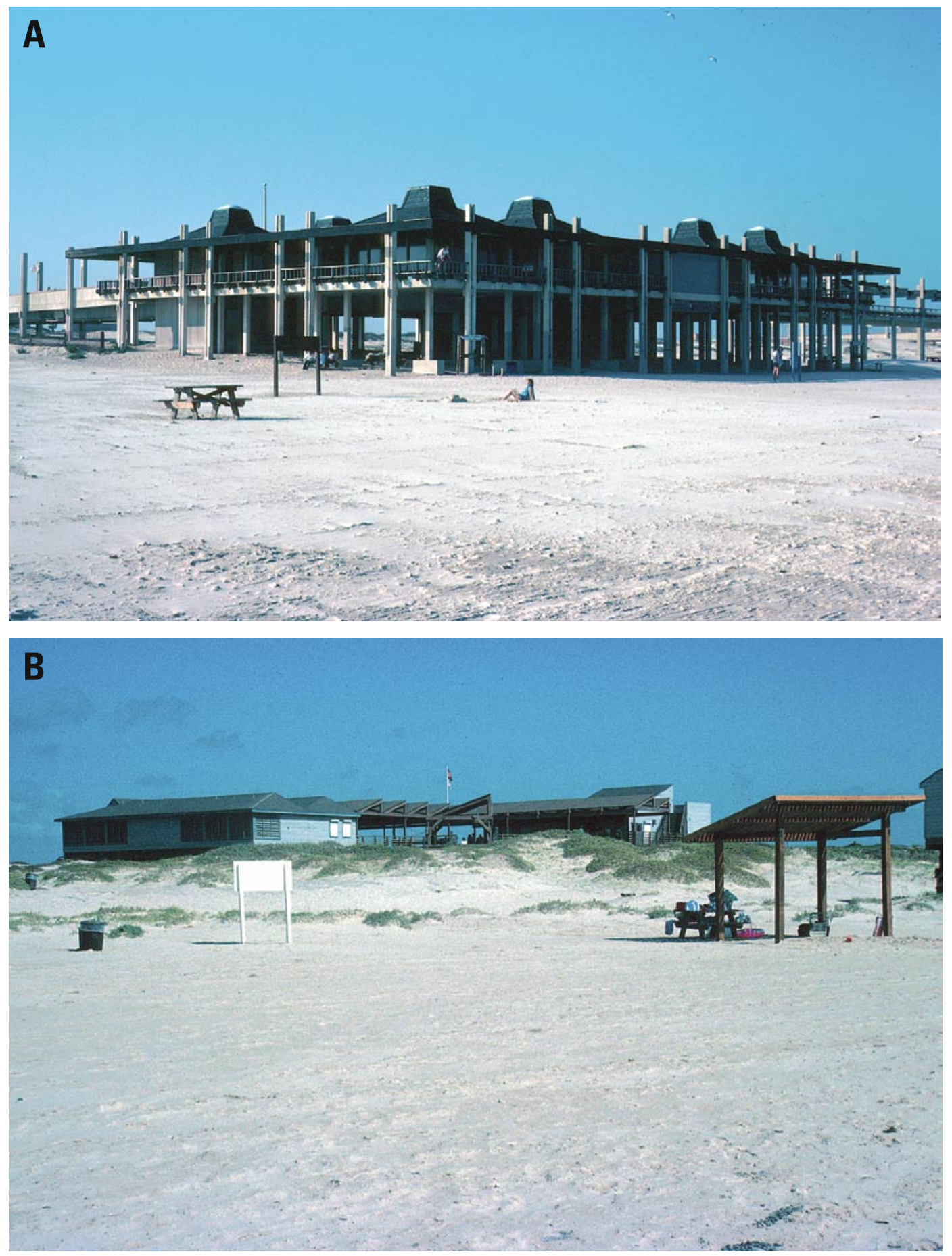

Figure 26. Visitor's center at Padre Island National Seashore, Texas in 1982 and 1992. The concrete reinforced structure built on the beach was torn down and a wooden structure was built landward of the dunes. 
and a major hurricane it was discovered that the pilings that supported the visitors center were structurally damaged. The facilities were declared a hazard to public safety, torn down, and a new building was constructed landward of the position of the former dune ridge (Fig. 26).

In some Gulf Coast states, involuntary retreat from the eroding shoreline has been the result of both physical and legal forces. The resulting landward relocation of houses and highways is designed to maintain a coastal presence while recognizing the inevitability of future coastal erosion. In Texas, several lawsuits resulted in the removal of a restaurant and a house from the Gulf beach because the buildings interfered with the public's use of the beach. Both structures were relocated to lots farther inland on the barrier islands.

\section{DISCUSSION AND FURTHER CONSIDERATIONS}

\section{Summary of Shoreline Changes}

According to measurements by the National Ocean Service, states bordering the Gulf of Mexico have $2610 \mathrm{~km}$ of open ocean coastline (Shalowitz, 1964). In this report, rates of shoreline change are provided for $1370 \mathrm{~km}$, or $52 \%$ of the total length of shore. Shoreline change analyses were not conducted for approximately $42 \%$ of the Gulf shore that is characterized by predominantly muddy shores and where a lidar-derived shoreline was unavailable (mangrove islands of southwest Florida, marshes of Florida Big Bend, and marsh-dominated segments of the Mississippi delta), and for $6 \%$ of the Gulf shore where all four shorelines were not present (Fig. 1).

Of the Gulf shoreline where rates of change were quantified, at least $830 \mathrm{~km}(61 \%)$ is eroding with average long-term rates as high as $36.8 \pm 14.2 \mathrm{~m} / \mathrm{yr}$. Short-term rates of change are comparable with about $750 \mathrm{~km}(55 \%)$ of the evaluated shore eroding in spite of beach nourishment and other attempts to stabilize the shore. The length and percentage of eroding shore would be even higher if the mangrove islands and marshes of Florida and Mississippi delta segments were included (see Hine and Belknap, 1986; Penland and others, 2000 respectively).

Rates of erosion for the Gulf of Mexico region are generally highest in Louisiana along barrier island and headland shores associated with the Mississippi delta. Both the highest long-term and short-term rates of erosion are anomalous and locally the result of barrier rotation or the shoreline crossing open water between two land features. Neither of these conditions could be sustained indefinitely, so the highest retreat rates could not be sustained. Erosion is also rapid along some barrier islands and headlands in Texas, and barrier islands in Mississippi are migrating laterally. High rates of erosion in Florida are generally localized around tidal inlets. Gulf shoreline change is greatly reduced along the west coast of Florida where low wave energy and frequent beach nourishment minimize erosion. Some beach segments in Texas have accreted as a result of net longshore drift convergence, and around tidal inlets that have been stabilized by long jetties.

Comparing long-term and short-term summary values for each state (Table $7 \mathrm{a}$ and $7 \mathrm{~b}$ ) shows a systematic decrease in the length (percent) of eroding shore. The decrease in eroding shore and complementary increase in accreting shore may partly be related to the systematic seaward offset in the lidar shoreline.

\section{Planned Updates and Related Research}

The USGS plans to revise and report on rates of shoreline change for the Gulf of Mexico every 5 to 10 years. The revision interval will depend on the need for updated information and technological advances that will allow relatively rapid shoreline position acquisition, processing, and dissemination. Future revisions will also incorporate the results of ongoing shoreline research. For example, we plan to evaluate the advantages and disadvantages of using the MHWL to determine if another datum-based shoreline would be more suitable for historical analysis. We will also explore other approaches to reduce shoreline positioning uncertainty (spatial errors) and shoreline sampling uncertainty (temporal variability). GPS technology has so greatly reduced positioning errors that they are no longer a significant component of the uncertainty analysis like they were in the past. GPS and lidar also eliminate the need for digitization and introduction of their associated positioning errors. Switching from the HWL to the operational MHWL will reduce some of the apparent short-term sampling variability that limits the reliability of the results. A datum-based shoreline that is higher on the beach profile than the operational MHWL might further reduce some of the short-term sampling variability by taking advantage of the more stable portion of the beach profile. The dynamics of sandy beaches ensure that short-term shoreline fluctuations will not be eliminated entirely from future shoreline positions, but data being collected in various coastal regions as part of the USGS regional studies will provide quantitative assessments of seasonal and interannual changes in shoreline position. These assessments will provide a means to determine if the detected shoreline change is within the expected range of movement and allow us to further constrain the uncertainties.

Another ongoing topic of research involves non-linear analysis of shoreline movement. It has been shown that time averaged linear methods of estimating future rates of shoreline movement (the existing paradigm) may not be appropriate for future predictions of shoreline position because coastal dynamics are non-linear. However, time series analyses based on non-linear theories require numerous 
shoreline positions (high sampling frequency) that generally are unavailable for most coastal areas.

\section{Influence of Human Activities}

As coastal communities expand along eroding shores of the Gulf of Mexico, potential conflicts may arise between preservation of upland property (typically privately owned) and conservation of the beach (typically publicly owned). Past social responses indicate that these conflicts most likely will be resolved through a combination of beach nourishment projects and shoreline protection structures. Both of these engineering responses to erosion alter the natural beach processes and eventually lead to shoreline positions that are not related to the natural unaltered rates of beach erosion.

Adding sand to eroding beaches is the most common method to mitigate storm damage and to maintain a recreational beach. Beach nourishment alters the rates of retreat by causing rapid artificial accretion of the shoreline. In those areas where nourishment is frequent, the trends of shoreline change will be biased toward accretion or stability, even though the beach is still eroding. Because many beaches are already altered by shoreline protection projects and many more will be altered in the future, the methods of analyzing shoreline movement will need to take shoreline stabilization activities into account so that the documented trends and derived rates of change can be expressed in their proper context.

Distinguishing between natural rates of shoreline movement and those influenced directly by human activities is crucial when historical rates of change are used for planning and to project future shoreline positions. Improved methods of analyzing shoreline movement will be needed to document the natural rates of shoreline change.

\section{REFERENCES}

Anders, F.J., and Byrnes, M.R., 1991, Accuracy of shoreline change rates as determined from maps and aerial photographs: Shore and Beach, v. 59, p. 17-26.

Barnard, P.L., 1998. Historical morphodynamics of inlet channels, west-central Florida. MS Thesis, University of South Florida, Tampa.

Barton, C.C., Dismukes, J.S., and Morton, R.A., 2003, Complexity analysis of the change in shoreline position at Duck, NC: Proceedings Coastal Sediments '03, 7p.

Boone, P.A., 1973, Depositional systems of the Alabama, Mississippi, and western Florida coastal zone: Transactions Gulf Coast Association of Geological Societies, v. 23, p. 266-277.

Bretschneider, C.L., 1954, Field investigation of wave energy loss of shallow water ocean waves: Beach Erosion Board Technical Memorandum No. 46, 21p.

Byrnes, M.R., McBride, R.A., Penland, S., Hiland, M.W., and Westphal, K.A., 1991, Historical changes in shoreline position along the Mississippi Sound barrier islands: Proceedings Gulf Coast Section SEPM Twelfth Annual Research Conference, p. 43-55.

Canis, W.F., Pilkey, O.H., Jr., Neal, W.J., Pilkey, O.H., Sr., Martin, D., and Belknap, D. F., 1985, Living with the Alabama-Mississippi shore: Duke University Press, Durham, N.C., 215 p.
Clark, R., 1986, The impact of Hurricane Elena and tropical storm Juan on coastal construction in Florida: Florida Department of Natural Resources, Division of Beaches and Shores, Report 85-3, 140p.

Clark, R., 1990, Coastal land loss in Florida: Transactions Gulf Coast Association of Geological Societies, v. 40, p. 117.

Clark, R., 1991, Beach conditions in Florida: Florida Department of Natural Resources, Division of Beaches and Shores, Technical Memorandum 89-1, 200p.

Coastal Erosion Subcommittee, 1996, Historical shoreline change in the northern Gulf of Mexico: U.S. Environmental Protection Agency, Gulf of Mexico Program, map scale 1:2,000,000.

Crowell, M., and Leatherman, S.P., eds., 1999, Coastal erosion mapping and management: Journal of Coastal Research, Special Issue 28, 196p.

Crowell, M., Douglas, B.C., and Leatherman, S.P., 1997, On forecasting future U.S. shoreline positions: A test of algorithms: Journal of Coastal Research, v. 13, p. 1245-1255.

Crowell, M., Leatherman, S.P., and Buckley, M.K., 1991, Historical shoreline change; Error analysis and mapping accuracy: Journal of Coastal Research, v. 7, p. 839-852.

Davis, R.A., 1994, Barriers of the Florida Gulf peninsula, in Davis, R.A., ed., Geology of Holocene Barrier Islands: Springer-Verlag, Berlin, p. 167-205. 
Davis, R.A., Hine, A.C., and Belknap, D.F., eds., 1985, Geology of the barrier island and marsh-dominated coast, west-central Florida: Geological Society of America, Annual Meeting Field Trip Guidebook, 119 p.

Davis, R.A., Jr., and Gibeaut, J.C., 1990. Historical morphodynamics of inlets in Florida, Models for coastal zone planning. Sea Grant College Technical Paper 55, 81p.

Dean, R.G., and O'Brian, M.P., 1987, Florida's west coast inlets: Shoreline effects and recommended action: Coastal and Oceanographic Engineering Department, University of Florida, Rept. 87/016, 100p.

Dean, J.L., and Pope, J., 1987, The Redington Shores breakwater project: initial response: Coastal Sediments '87, American Society of Civil Engineers, v. 2, p. 1369-1384.

Dean, R.G., Cheng, J., and Malakar, S.B., 1998, Characteristics of the shoreline change along the sandy beaches of the state of Florida: An atlas: Florida Sea Grant Report UFL/COEL-98/015, variable pagination.

De Beaumont, L.E., 1845, Lecons de geologie practique: Septieme lecon, Bertrand Paris, p. 221-252.

Dixon, K.L., and Pilkey, O.H., 1991, Summary of beach replenishment on the U.S. Gulf of Mexico shoreline: Journal of Coastal Research, v. 7, p. 249-256.

Dolan, R., Anders, F., and Kimball, S., 1985, Coastal erosion and accretion, in National Atlas of the United Sates of America: U.S. Geological Survey, Reston, Va.

Douglas, B.C., and Crowell, M., 2000, Long-term shoreline position prediction and error propagation: Journal of Coastal Research, v. 16, p. 145-152.

Doyle, L.J., Sharma, D.C., Hine, A.C., Pilkey, O.H., Jr., Neal, W.J., Pilkey, O.H., Sr., Martin, D., Belknap, D.F., 1984, Living with the West Florida shore: Duke University Press, Durham, N.C., 222p.

Gabrysch, R.K., 1984, Ground-water withdrawals and land-surface subsidence in the Houston-Galveston region, Texas: Texas Department of Water Resources Report 287, 64p.

Gilbert, G.K., 1885, The topographic features of lake shores: U.S. Geological Survey $5^{\text {th }}$ Annual Rept., p. 69-123.

Gould, H.R., and McFarlan, E., Jr., 1959, Geologic history of the chenier plain southwestern Louisiana: Transactions Gulf Coast Association of Geological Societies, v. 9, p. 261-270.
Gornitz, V., and Lebedeff, S., 1987, Global sea level changes during the last century, in Nummedal, D., Pilkey, O. H., and Howard, J. D., eds., Sea-level fluctuation and coastal evolution: Society of Economic Paleontologists and Mineralogists, Special Publication 41, p. 3-16.

Hardin, J.D., Sapp, C.D., Emplaincourt, J.L., and Richter, K.E., 1976, Shoreline and bathymetric changes in the coastal area of Alabama: Geological Survey of Alabama, Information Series 50, $123 \mathrm{p}$.

The Heinz Center, 2000, Evaluation of erosion hazards: The H. John Heinz III Center for Science, Economics and the Environment, Washington, D.C., 203p.

Hicks, S.D., 1968, Long-period variations in secular sea level trends; Shore and Beach, v. 36, p. 32-36.

Hine, A.C., and Belknap, D.F., 1986, recent geologic history and modern sedimentary processes of the Pasco, Hernando, and Citrus County coastline, West Central Florida: Florida Sea Grant, Technical Report No. 79, 166 p.

Holdahl, S.R., and Morrison, N.L., 1974, Regional investigations of vertical crustal movements in the U.S using precise relevelings and mareograph data: Tectonophysics, v. 23, p. 373-390.

Hoyt, J.H., 1967, Barrier island formation: Geological Society of America Bulletin, v. 78. p. 1125-1135.

Jurkowski, G., Ni, J., and Brown, L., 1984, Modern uparching of the Gulf Coastal plain: Journal of Geophysical Research, v. 89, p. 6247-6255.

Krabill, W., Wright, C., Swift, R., Frederick, E., Manizade, S., Yungel, J., Martin, C., Sonntag, J., Duffy, M., Hulslander, W., and Brock, J., 2000. Airborne laser mapping of Assateague National Seashore Beach. Photogrammetric Engineering \& Remote Sensing, v. 66, p. 65-71.

Lyles, S.D., Hickman L.E., Jr., Debaugh, H.A., Jr., 1988, Sea-level variations for the United States 1855-1986: U.S. Department of Commerce, NOAA-NOS, Rockville Md., 182p.

McBride, R.A., Penland, S., Hiland, M.W., Williams, S.J., Westphal, K.A., Jaffee, B.E., and Sallenger, A.H., 1992, Analysis of barrier shoreline change in Louisiana from 1853 to 1989, in Williams, S.J., Penland, S., and Sallenger, A.H., eds., Atlas of shoreline changes in Louisiana from 1853 to 1989: U.S. Geological Survey Miscellaneous Investigation Series I-2150-A, p. 36-97.

McGee, W.D., 1890, Encroachments of the sea: The Forum, v. 9 , p. 437-449.

Moore, L. J., 2000, Shoreline mapping techniques: Journal of Coastal Research, v. 16, p. 111-124 
Moore, W.S., 1982, Late Pleistocene sea-level history, in Ivanovitch, M., and Harmon, R.S., eds., Uranium series disequilibrium: applications to environmental problems: Oxford, Claredon, p. 481-506.

Morgan, J.P., and Larimore, P.B., 1957, Changes in the Louisiana shoreline: Gulf Coast Association of Geological Societies Transactions, v. 7, p. 303-310.

Morton, R.A., 1976, Effects of Hurricane Eloise on beach and coastal structures, Florida Panhandle: Geology, v. 4, p. 277-280.

Morton, R.A., 1977a, Historical shoreline changes and their causes, Texas Gulf Coast: Gulf Coast Association of Geological Societies Transactions, v. 27, p.352-364.

Morton, R.A., 1977b, Shoreline changes at jettied inlets, Texas Gulf Coast: Coastal Sediments '77, American Society of Civil Engineers, p. 267-286.

Morton, R.A., 1979, Temporal and spatial variations in shoreline changes, Texas Gulf Coast: Journal of Sedimentary Petrology, v. 49, p. 1101-1111.

Morton, R.A., 1988, Interactions of storms, seawalls and beaches of the Texas coast, in Kraus, N.C., and Pilkey, O.H., Effects of seawalls on the beach: Journal of Coastal Research, Special Issue 4, p. 113-134.

Morton, R.A., 1991, Accurate shoreline mapping: past, present, and future: American Society of Civil Engineers, Coastal Sediments '91, v. 1, p. 997-1010.

Morton, R.A., 1994, Texas Barriers, in Davis, R.A., ed., Geology of Holocene Barrier Islands: Springer-Verlag, Berlin, p. 75-114.

Morton, R.A., 1996, Geoindicators of coastal wetlands and shorelines, in Berger, A.R., and Iams, W.J., eds., Geoindicators: Assessing rapid environmental changes in earth systems: A.A. Balkema, Rotterdam, p. 207-230.

Morton, R.A., 1997, Gulf shoreline movement between Sabine Pass and the Brazos River, Texas: 1974-1996: Univ. of Texas Austin, Bureau of Economic Geology Geological Circular 97-3, 46p.

Morton, R.A., 2002, Factors controlling storm impacts on coastal barriers and beaches - A preliminary basis for real-time forecasting: Journal of Coastal Research, v. 18, p. 486-501.

Morton, R.A., and Paine, J.G., 1990, Coastal land loss in Texas - An overview: Transactions Gulf Coast Association of Geological Societies, v. 40, p. 625-634.
Morton, R.A., Buster, N.A., and Krohn, M.D., 2002, Subsurface controls on historical subsidence rates and associated wetland loss in southcentral Louisiana: Transactions Gulf Coast Association of Geological Societies, v. 52, p. 767-778.

Morton, R.A., and Speed, F.M., 1998, Evaluation of shorelines and legal boundaries controlled by water levels on sandy beaches: Journal of Coastal Research, v. 14, p. 1373-1384.

Otvos, E.G., 1979, Barrier island evolution and history of migration, north central Gulf Coast, in Leatherman, S.P. ed., Barrier islands from the Gulf of St. Lawrence to the Gulf of Mexico: Academic Press, New York, p. 291-319.

Paine, J.G., and Morton, R.A., 1989, Shoreline and vegetation line movement, Texas Gulf Coast, 1974-1982: The University of Texas at Austin, Bureau of Economic Geology, Geological Circular 89-1, 50p.

Pajak, M.J., and Leatherman, S.P., 2002, The high water line as shoreline indicator: Journal of Coastal Research, v. 18, p. 329-337.

Penland, S., Roberts, H.H., Williams, S.J., Sallenger, A.H., Cahoon, D.R., Davis, D.W., and Groat, C.G., 1990 Coastal land loss in Louisiana: Transactions Gulf Coast Association of Geological Societies, v. 40, p. 685-699.

Penland, S., Wayne, L., Britsch, L.D., Williams, S.J., Beall, A.D., and Caridas, V., 2000, Process Classification of Coastal Land Loss between 1932 and 1990 in the Mississippi River Delta Plain, Southeastern Louisiana: USGS Open-file Report 00-418.

Price, W.A., 1953, Shorelines and coasts of the Gulf of Mexico: U.S. Fish and Wildlife Service Fishery Bulletin No. 89 , p. 39-65.

Roberts, H.H., Bailey, A., and Kuecher, G.J., 1994, Subsidence in the Mississippi River delta - Important influences of valley filling by cyclic deposition, primary consolidation phenomena, and early diagenesis: Gulf Coast Association of Geological Societies Transactions, v. 44, p. 619-629.

Rucker, J.B., and Snowden, J.O., 1988, Recent morphological changes at Dog Key Pass, Mississippi: The formation and disappearance of The Isle of Caprice: Gulf Coast Association of Geological Societies Transactions, v. 38, p. 343-349.

Ruggiero, P., Kaminsky, G.M., and Gelfenbaum, G., 2003, Linking proxy-based and datum-based shorelines on a high-energy coastline: Implications for shoreline change analyses: Journal of Coastal Research Special Issue 38, p. 57-82. 
Sallenger, A.H., Krabill, W., Swift, R., Brock, J., List, J., Hansen, M., Holman, R.A., Manizade, S., Sontag, J., Meredith, A., Morgan, K., Yunkel, J.K., Frederick, E. and Stockdon, H., 2003. Evaluation of airborne scanning lidar for coastal change applications: Journal of Coastal Research, v.19, p. 125-133.

Sanchez, T.A., and Douglass, S.L., 1994. Alabama shoreline change rates: 1970-1993: University of South Alabama College of Engineering Report 94-1.

Schwartz, M.L., 1971, The multiple causality of barrier islands: Journal of Geology, v. 79, p. 91-94.

Shalowitz, A.L., 1964, Shore and sea boundaries. Publication 10-1, U.S. Department of Commerce, Washington, DC, 749p.

Simpson, R.H., and Lawrence, M.B., 1971, Atlantic hurricane frequencies along the U.S. coastline: National Oceanic and Atmospheric Administration, NOAA Technical Memorandum NWS SR-581, 15p.

Smith, E., 1990, Regimes contributory to progressive loss of Alabama coastal shoreline and wetlands: Transactions Gulf Coast Association of Geological Societies, v. 40, p. 793-796.

Stauble, D.K., and Brumbaugh, R.W., 2003, An assessment of the nation's shorelines, USA: Shore and Beach, v. 71, p. 11-18.

Stockdon, H.F., Sallenger, A.H., List, J.H. and Holman, R.A., 2002, Estimation of shoreline position and change from airborne topographic lidar data. Journal of Coastal Research, v. 18, p. 502-513.

Swanson, R.L., and Thurlow, C.L., 1973, Recent subsidence rates along the Texas and Louisiana coasts as determined from tide measurements: Journal of Geophysical Research, v. 78, 2665-2671.

Tanner, W.F., 1960, Florida coastal classification: Transactions Gulf Coast Association of Geological Societies, v. 10, p. 259-265.

Tanner, W.F., 1975, Historical beach changes, Florida's Big Bend Coast: Transactions Gulf Coast Association of Geological Societies, v. 25, p. 379-381.

Thieler, E.R., and Danforth, W.W., 1994, Historical shoreline mapping (1). Improving techniques and reducing positioning errors: Journal of Coastal Research, v. 10, p. 549-563.

Trembanis, A.C., and Pilkey, O.H., 1998, Summary of beach nourishment along the U.S. Gulf of Mexico shoreline: Journal of Coastal Research, v. 14, p. 407-417.
U.S. Army Corps of Engineers, 1971, National shoreline study: Washington, D.C.

U.S. Army Corps of Engineers, 1983, Galveston County shore erosion study-feasibility report and environmental impact statement: Gulf shoreline study site report, v. 2, Galveston District Corps of Engineers, 44p.

U.S. Army Corps of Engineers, 1984, Beach erosion control project review study and environmental impact statement for Pinellas County, Florida: U. S. Army Engineer Jacksonville District, various pagination.

Waller, T.H., and Malbrough, L.P., 1976, Temporal changes in the offshore islands of Mississippi: Mississippi State University Water Resources Institute, 109 p.

White, W.A., Morton, R.A., Kerr, R.S., Kuenzi, W.D., and Brogden, W.B., 1978, Land and water resources, historical changes, and dune criticality, Mustang and North Padre Islands, Texas: The University of Texas at Austin, Bureau of Economic Geology Report of Investigations No. $92,46 \mathrm{p}$. 